UNIVERSIDADE DE SÃO PAULO

FACULDADE DE ADMINISTRAÇÃO, ECONOMIA E CONTABILIDADE DEPARTAMENTO DE ADMINISTRAÇÃO PROGRAMA DE PÓS-GRADUAÇÃO EM ADMINISTRAÇÃO

CONTINGÊNCIA DE CRISES FINANCEIRAS: UM ESTUDO SOBRE A EVOLUÇÃO DA REGULAÇÃO DOS MERCADOS E O RISCO DAS INSTITUIÇÕES FINANCEIRAS NO BRASIL

Thiago Navarro Mafra Amorim

Orientador: Prof. Dr. José Roberto Securato

SÃO PAULO 
Prof. Dr. João Grandino Rodas

Reitor da Universidade de São Paulo

Prof. Dr. Reinaldo Guerreiro

Diretor da Faculdade de Economia, Administração e Contabilidade

Prof. Dr. Adalberto Américo Fischmann
Chefe do Departamento de Administração

Prof. Dr. Lindolfo Galvão de Albuquerque

Coordenador do Programa de Pós-Graduação em Administração 


\section{Contingência de crises financeiras: Um estudo sobre a evolução da regulação dos mercados e o risco das instituições financeiras no Brasil}

Dissertação apresentada ao Programa de PósGraduação em Administração da Universidade de São Paulo, para obtenção do título de mestre. 


\section{SÃO PAULO}

2011

\section{FICHA CATALOGRÁFICA}

Elaborada pela Seção de Processamento Técnico do SBD/FEA/USP

Amorim, Thiago Navarro Mafra

Contingência de crises financeiras: um estudo sobre a evolução da regulação dos mercados e o risco das instituições financeiras no Brasil / Thiago Navarro Mafra Amorim. -- São Paulo, 2011.

$123 \mathrm{p}$.

Dissertação (Mestrado) - Universidade de São Paulo, 2011.

Orientador: José Roberto Securato.

1. Administração financeira 2. Crise financeira 3. Risco 4. Finanças Regulação 5. Finanças comportamentais I. Universidade de São Paulo. Faculdade de Economia, Administração e Contabilidade II. Título.

CDD -658.15 


\section{AGRADECIMENTOS}

Agradeço à Deus.

Ao meu orientador Prof. Dr. José Roberto Securato, agradeço por todos os ensinamentos, técnicos e sobre a vida, que me proporcionou durante este período inesquecível do mestrado. Ele certamente não se lembrará, mas no ano de 2000 tive o privilégio de tê-lo como professor em minha primeira disciplina de finanças, ainda na graduação. Neste momento tive a certeza que o estudo e o ensino de finanças poderia ser apaixonante. Obrigado por tudo. Serei sempre muito grato.

Aos membros da banca examinadora. Ao Prof. Dr. Andre Luiz Oda agradeço por toda atenção que me proporcionou quando decidi aplicar para o mestrado, e por sua minuciosa verificação no exame de qualificação. Ao ingressar no mestrado, não tinha dúvidas que gostaria muito de contar com a honra ter sua presença em minha banca. Ao Prof. Dr. Rafael Paschoarelli Veiga, agradeço por suas valiosas sugestões no exame de qualificação, por todos os ensinamentos didáticos que me proporcionou quando fui seu monitor na graduação, e por sua disposição em me ajudar com qualquer tipo de dúvida. Não tenho dúvida que tenho a honra de ter em minha banca dois dos mais promissores professores formados e atuantes nesta Universidade.

Aos meus pais, agradeço muito por todo suporte, carinho e incentivo para evoluir sempre. Sem vocês nada disso teria sido possível.

Ao corpo de funcionários da FEA -USP, especialmente secretarias e biblioteca. Tenho um carinho muito grande pela FEA-USP. Posso dizer que me sinto em casa quando estou na FEA, e vocês contribuem muito para isso.

Aos professores com quem tive o privilégio de ter aulas no mestrado. Em especial ao Prof. Dr. Abraham Sin Oih Yu, Prof. Dr. Almir Ferreira de Sousa, Profa. Dr. Bernadete de Lourdes Marinho, Profa. Dr. Leda Maria Paulani, Prof. Dr. José Roberto Ferreira Savoia, Prof. Dr. Keyler Rocha.

Aos muitos amigos que fiz durante o mestrado. Em especial aos amigos Bruno Buscariolli Pereira e Alan Nader Ghani.

À minha tia Maria Inez Amorim, figura atuante em educação, pela alegria contagiante e estímulo desde o processo seletivo para ingressar neste mestrado.

Por último, e certamente não menos importante, à Silvia por me inspirar. Por me ajudar a descobrir que a dedicação acadêmica é apaixonante. Pelo afeto, carinho, dedicação e companheirismo incondicional. 
“All people are most credulous when they are most happy" (Galbraith, 1993. p 6) 


\section{RESUMO}

A recente crise financeira de 2007/2008 - a maior e mais intensa desde a grande crise de 1929 - surpreendeu autoridades governamentais, acadêmicos e profissionais de mercado. Gestada ao longo de muitos anos, mesmo passados mais de dois anos do ápice da crise, ainda não há consenso a respeito da principal causa do desastre. Se tomarmos como aprendizado a análise de crises passadas, vemos que raramente há uma causa singular. Com a crise recente não foi diferente. Embora não haja um consenso, o debate relacionando a crise com possíveis falhas na regulação dos mercados ganhou força. Para muitos, a falta de regulação foi o principal fator que permitiu que intermediários financeiros assumissem mais risco do que efetivamente pudessem arcar. Mas houve efetivamente evolução do arcabouço regulatório nos últimas duas décadas. Seria a regulação desenvolvida até a crise errada, incompleta ou não aplicada? O objetivo deste trabalho foi o de investigar se eventos regulatórios afetam o risco dos bancos brasileiros de capital aberto listados na Bolsa de Valores de São Paulo (Bovespa). O estudo compreendeu as ações listadas na data dos eventos observados. A listagem das ações dos bancos analisados foi subdividida em dois grupos, seguindo o critério do tamanho do ativo total. Esta medida foi tomada de forma a minimizar diferenças de impacto que possivelmente seriam geradas em bancos de portes distintos. Como metodologia de teste, utilizou-se o estudo de evento. As hipóteses do estudo testaram o impacto no risco gerado em dois marcos regulatórios: (i) Comunicado número 12.746, de 8 de dezembro de 2004, que determinou os procedimentos para a implementação da nova estrutura de capital - Basiléia I- no Brasil; (ii) Concordata do Banco Lehman Brothers, em 15 de setembro 2008, estopim da crise financeira de 2008, momento em que a imposição de maiores limites regulatório aos Bancos passou a ser discutido com grande veemência. Os resultados observados sugerem que não houve impacto estatisticamente significante - tanto no que diz respeito ao evento 1 quanto ao evento 2 - no risco das instituições financeiras atuantes no mercado nacional. O resultado é válido tanto para o grupo formado pelas $50 \%$ maiores instituições do mercado quanto para as $50 \%$ menores instituições. 


\begin{abstract}
The recent financial crises that occurred between 2007/2008 - the largest and most devastating since the great depression of 1929 - has surprised government authorities, academics and financial market professionals. Nurtured during several years and even after more than two year of the climax of the crises, there is still no consensus about it causes. Based on learnings of the past economic crises that the world has faced, it is impossible to single source the cause for the crises. Many argue that the lake of regulation should be the main causes of the crises. But it's possible to state that the financial regulation worldwide has faced a strong development in the last two decades. Could it be consider that the financial regulation developed up to the crises was wrong, incomplete or not applied? The main objective of this work was to investigate if the selected regulatory events affected the risk of the most relevant banks with operations in Brazil and listed in Bolsa de Valores de São Paulo (Bovespa). This study took into account specific banks' stocks values listed in Bovespa during the observed period. In order to minimize possible differences of impacts that the regulatory policies may have over banks of distinct sizes, the sample was subdivided in two groups, considering their asset size. The test methodology applied on this work is the event study. The hypotheses of the study tested the impact on risk during two regulatory milestones: (i) communication number 12.746 of December 8, 2004, which determined the procedures for the implementation of new capital structure - Basiléia I in Brazil; and (ii) the bankruptcy of Lehman Brothers on September 15, 2008; starting point of the financial crises of 2008, and, also, the moment of application of news regulatory limits to the banks was most intensive discussed. The results observed suggest that there is no statistically significant impact on to the risk of the banks analyzed, for both events observed.
\end{abstract}





\section{SUMÁRIO}

1 INTRODUÇÃ

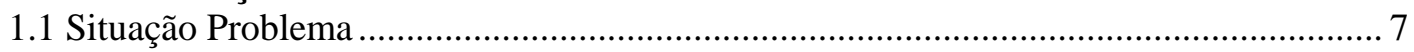

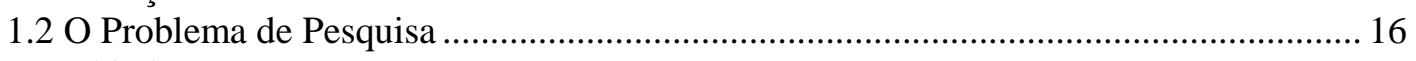

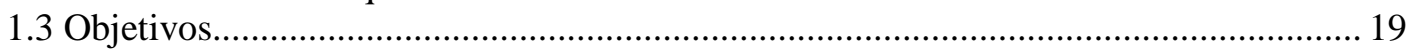

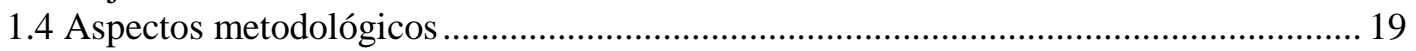

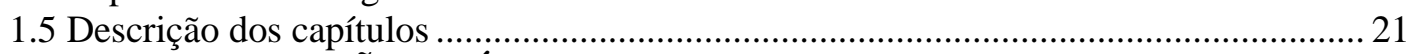

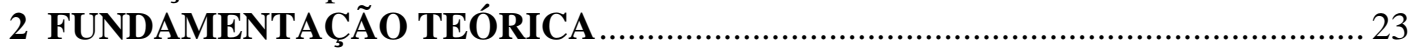

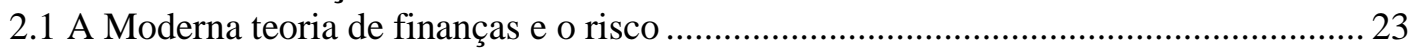

2.1.1 A Teoria de Carteiras de Markowitz e as Decisões em Condições de Risco .............. 23

2.1.2 Tratamento do Risco Sistêmico - O modelo do CAPM .............................................. 31

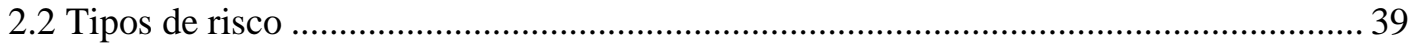

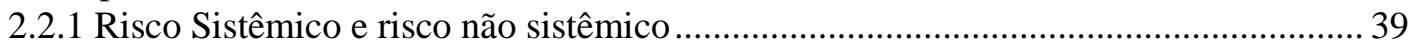

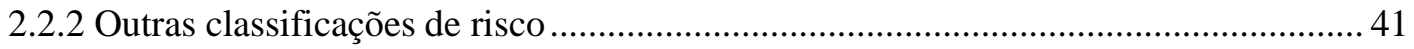

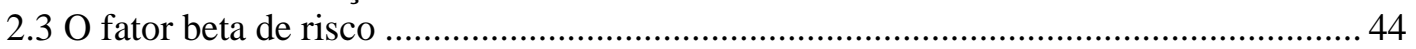

2.4 Hipótese de mercados eficientes (HME) ............................................................... 46

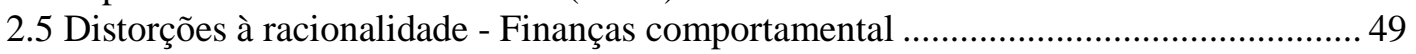

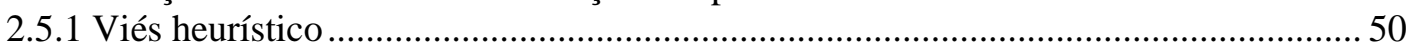

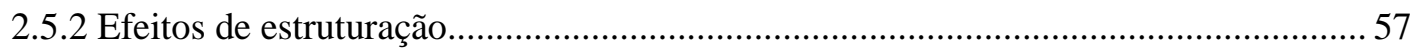

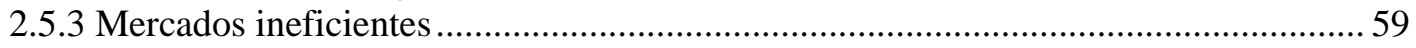

2.6 Discrepância comportamental na prática - O disposition effect ...................................... 62

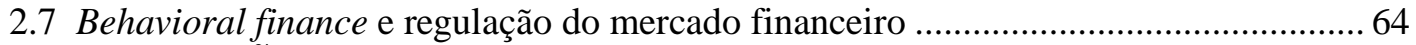

3 REGULAÇÃO DO RISCO PARA MERCADOS FINANCEIROS ……..................6 67

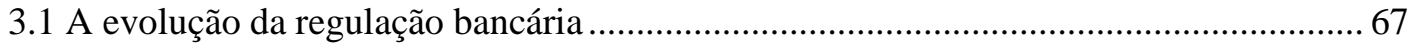

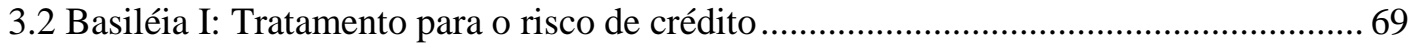

3.3 Insuficiências do acordo da Basiléia I e a transição para um Novo Acordo ................... 73

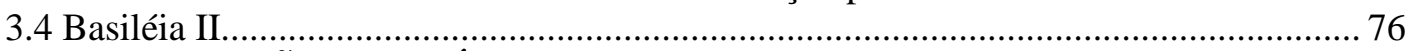

4 A REGULAÇÃO BANCÁRIA PARA CONTROLE DE RISCO NO BRASIL ....... 87

4.1 O Acordo da Basiléia I, os Regulamentos Domésticos e os Controles Internos ............87 87

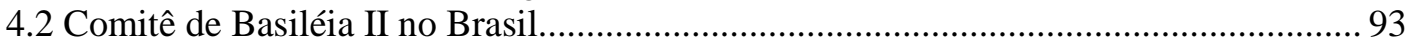

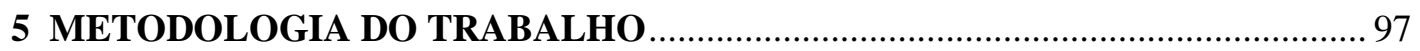

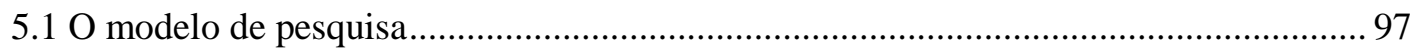

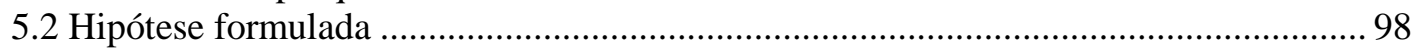

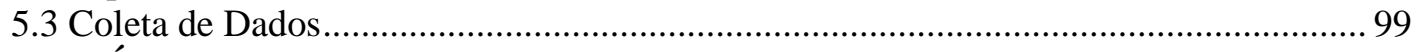

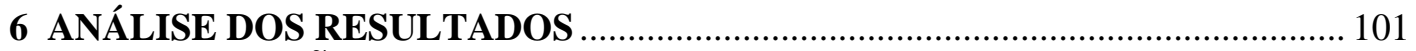

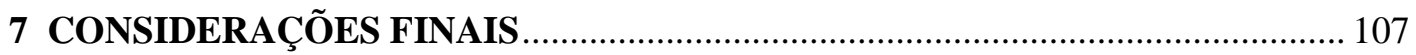




\section{LISTA DE ABREVIATURAS E SIGLAS}

$\begin{array}{ll}\text { AMA } & \text { Advanced Measurement Approaches } \\ \text { APR } & \text { Ativo Ponderado pelo Risco } \\ \text { APS } & \text { Abordagem padrão simplificada } \\ \text { BC } & \text { Banco Central } \\ \text { BCBS } & \text { Basel Committe on Banking Supervision } \\ \text { BIS } & \text { Bankfor International Settlements } \\ \text { CAPM } & \text { Capital Asset Pricing Model } \\ \text { CMN } & \text { Conselho Monetário Nacional } \\ \text { EUA } & \text { Estados Unidos da América } \\ \text { FED } & \text { Federal Reserve System } \\ \text { FGC } & \text { Fundo Garantidor de Crédito }, \\ \text { FMI } & \text { Fundo Monetário Internacional } \\ \text { HME } & \text { Hipótese de Mercados Eficientes } \\ \text { IBOVESPA } & \text { Índice da Bolsa de Valores de São Paulo } \\ \text { IIF } & \text { Institute of International Finance } \\ \text { IPO } & \text { Initial Public Offering } \\ \text { IRB } & \text { Internal Risk Based Approaches } \\ \text { K-S } & \text { Kolmogorov-Smirnov } \\ \text { LMC } & \text { Linha de Mercado de Capitais } \\ \text { LPFin } & \text { Laboratório de Pesquisas em Finanças } \\ \text { MP } & \text { Medida Provisória } \\ \text { NFE } & \text { Nova Fronteira Eficiente } \\ \text { OCDE } & \text { Organização para a Cooperação e Desenvolvimento Econômico } \\ \text { PIB } & \text { Produto Interno Bruto } \\ \text { PLA } & \text { Patrimônio Líquido Ajustado } \\ \text { PLE } & \text { Patrimônio Líquido Exigido } \\ \text { PR } & \text { Patrimônio de Referência } \\ \text { PRE } & \text { Patrimônio de Referência Exigido } \\ \text { PROER } & \text { Programa de Estímulo à Reestruturação e ao Fortalecimento do } \\ \text { Sistema Financeiro Nacional } \\ \text { PROES } & \text { Programa de Incentivo à Redução da Presença do Setor Público } \\ \text { Estadual na Atividade Financeira Bancária } \\ \text { SFN } & \text { Sistema Financeiro Nacional } \\ \text { SML } & \text { Security Market Line } \\ \text { Var } & \text { Value at Risk } \\ \end{array}$




\section{LISTA DE TABELAS}

Tabela 1 - Ranking das bancos em dezembro/2004 ...................................................... 101

Tabela 2 - Ranking das bancos em dezembro/2008 ........................................................... 102

Tabela 3- Retorno Acionário Semanal Médio e beta dos bancos (período de 24 meses anterior e posterior ao comunicado n. 12.746, de 8 de dezembro de 2004)

Tabela 4- Retorno Acionário Semanal Médio e beta dos bancos (período de 24 meses anterior e posterior à concordata do Banco Lehman Brothers, em 15 de setembro 2008)

Tabela 5- Teste de normalidade das distribuições para evento 1 (Shapiro-Wilk) .... 103

Tabela 6 - Teste de normalidade das distribuições para evento 1, excluindo banco do Estado do Piauí (Shapiro-Wilk) 104

Tabela 7- Teste de normalidade das distribuições para evento 2 (Shapiro-Wilk) .... 104 Tabela 8 - Teste $\mathbf{T}$ de comparação de médias para amostras emparelhadas: análise do desvio padrão anterior e posterior ao evento regulatório 105 


\section{LISTA DE GRÁFICOS}

Gráfico 1 - Relação entre retorno esperado e risco da carteira, para $\rho=1$................... 28

Gráfico 2 - Relação entre retorno esperado e risco da carteira, para $\rho=-1$................. 29

Gráfico 3 - Relação entre retorno esperado e risco da carteira para $\rho<1$ e $\rho>-1$.... 29

Gráfico 4 - Curvas de oportunidade para a carteira formada pelos ativos a e b......... 30

Gráfico 5 - Fronteira Eficiente e a Linha de Mercado de Capitais ................................. 32

Gráfico 6 - Relação entre um Ativo Individual e a LMC ..........................................35

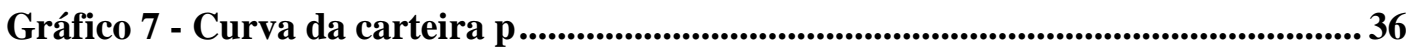

Gráfico 8 - Classificações de risco segundo Jorion (2000) ............................................... 43

Gráfico 9- Uma função de valor hipotético..............................................................55 


\section{LISTA DE QUADROS}

Quadro 1: Fatores de ponderação por categoria de ativos ................................................ 72

Quadro 2: Ponderação conforme o rating.......................................................................... 80

Quadro 3: Linhas de negócios - abordagem padronizada................................................83

Quadro 4: Níveis de risco da Resolução 2.682 ................................................................... 92

Quadro 5: Prazos de implementação de Basiléia II no Brasil, conforme comunicado

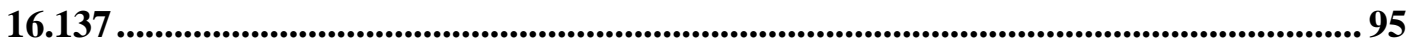

Quadro 6: Definição dos grupos de análise ..................................................................99 
LISTA DE FIGURAS

Figura 1: Os três pilares de Basiléia II 79

Figura 2: Pilar I - Alocação de capital .......................................................................... 79

Figura 3: Procedimento para determinação do risco..................................................98 


\section{INTRODUÇÃO}

\subsection{Situação Problema}

Os mercados, e em particular os mercados financeiros, sempre foram, são e sempre serão afetados pela interação de oportunidades, incertezas e riscos. Mas a exposição exacerbada a riscos gera vulnerabilidades financeiras que mostram seu lado mais perigoso justamente em momentos de queda brusca no mercado, quando a euforia do mercado subitamente muda de humor. Na filosofia sábia do mega investidor Warren Buffet, é quando a maré baixa que se descobre quem estava nadando nu.(BUFFET, CLARK, 2007). Ou nas palavras de Galbraith: "Gênio financeiro é antes da queda ${ }^{1} . "($ GALBRAITH, 1993, p.17).

Para Galbraith (1993), a euforia que precede uma grande crise financeira é fruto de dois fatores. O primeiro refere-se à memória curta em relação aos fatos financeiros, fazendo com que desastres financeiros sejam rapidamente esquecidos. Para o autor, em praticamente nenhuma outra esfera do esforço humano a história vale tão pouco quanto no mundo das finanças.

O segundo fator que contribui para a euforia especulativa é a comum associação entre dinheiro e inteligência. Dinheiro é a medida do capitalismo, e assim, quanto mais dinheiro um indivíduo possui, maior a inteligência que suporta essa condição. $\mathrm{O}$ autor faz uma referência direta à comum associação de inteligência que se faz aos líderes de grandes instituições financeiras.

Ele, ela, ou eles são então dotados de autoridade que incentiva consentimento de seus subordinados e aplausos de seus seguidores e que exclui opinião adversa ou crítica. Eles são então admiravelmente protegidos em algo que pode ser um sério comprometimento com erro. (GALBRAITH, 1993, p.15-16) ${ }^{2}$.

\footnotetext{
1 "Financial genius is before the fall."

2 "He, she, or they are then endowed with the authority that encourages acquiescence from their subordinates and applause from their acolytes and that excludes adverse opinion or criticism. They are thus admirably protected in what may be a serious commitment to error."
} 
Episódios envolvendo especulação de preços certamente não são novos na sociedade, fazendo parte da história há séculos. Notas bancárias, títulos, terras, objetos de artes, imóveis são alguns dos exemplos de ativos que já protagonizaram alta de preços em um processo muitas vezes marcado pela irracionalidade, atraindo novos compradores confiantes na perspectiva que novos aumentos ocorreriam no futuro próximo.

Estaria o mercado se ajustando para um novo patamar de preços - uma nova economia marcada por novas oportunidades de ganhos e retornos excessivos? Ou seria apenas uma onda passageira de otimismo, gerando oportunidades de ganhos especulativos? Este ganho é fruto certo de uma intuição muito bem apurada do investidor, ou há um alto nível de risco envolvido na situação marcada pela euforia financeira? Qual seria o momento certo para o investidor deixar de surfar essa onda otimista, vislumbrando o humor especulativo do momento? E porque poucos economistas previram a chegada da crise financeira de 2008 ?

Uma crise financeira da proporção como a ocorrida em 2008 é gestada durante um longo período de tempo, e distintos fatores podem desencadear uma ruptura de tal proporção.

De forma geral, a gradual desregulamentação financeira no mercado financeiro mundial - sobretudo nos EUA, Europa e Japão a partir de 1980 - é apontada por estudiosos como um dos principais fatores causadores da recessão de 2008.

Até os anos 80, vigorava a regulação financeira erguida após a Grande Depressão, imprimindo durante quarenta anos restrições relevantes no que diz respeito à exposição a riscos na intermediação financeira bancária (SILBER, 2010, p.86).

O autor destaca como ponto de partida da regulação nos Estados Unidos a Glass Steagal Act (1933), separando bancos de investimentos e bancos comerciais; a Securities Act e Securities Exchange Act (1934), criando a Securities and Exchange Comission, com autoridade para regular e fiscalizar o mercado acionário americano; o Banking Act (1935), dando maior autonomia ao Federal Reserve, e o Banking Holding Company Act (1956), restringindo a participação os bancos em empresas não bancárias. 
A partir dos anos 70 o setor financeiro passa a conquistar uma participação cada vez maior na atividade econômica global. Nos Estados Unidos, a participação do lucro do setor em relação ao lucro total doméstico americano evolui, de uma média de $15 \%$ na primeira metade dos anos 80, para 40\% entre 2002 e 2003 (SILBER, 2010).

Em paralelo inicia-se um movimento em direção a desregulamentação do mercado financeiro, desmontando gradualmente grande parte da legislação desenvolvida com o intuito de limitar a atividade bancária.

Nesse sentido, Bresser (2010) ressalta que na década de 1970 a macroeconomia neoclássica substituía a keynesiana, e a economia do desenvolvimento - definida pelo autor como a estratégia de desenvolvimento encabeçada pelo Estado - cai no ostracismo, inclusive nas universidades. A chamada ideologia neolibeal ganha destaque.

O neoliberalismo também procurava reduzir o porte do Estado e desregular todos os mercados, principalmente, os financeiros. Alguns argumentos usados para justificar a nova abordagem foram [...] a defesa dos mercados auto-regulados e dos mercados financeiros eficientes [...] (BRESSER, 2010, p. 55).

Neste período há um notável aumento do crédito em forma de títulos negociados por fundos de investimentos - como os fundos mútuos ou fundos de hedge ampliando a antiga base de créditos até então dependente de empréstimos de bancos a empresas.

Somado a ampliação da base de empréstimos, há o surgimento das chamadas inovações financeiras - como securitização, swaps e veículos especiais de investimentos - que permitiam os bancos limparem seus balanços dos efetivos riscos inerentes às operações. Na prática, bancos passam a operar com uma alavancagem crescente de seus balanços.

Enquanto os resultados financeiros, de uma forma geral, apresentavam razoável nível de estabilidade, não haveria reais motivos para uma maior preocupação com as mudanças que vinham ocorrendo. Entre 1985 e 2007, durante a grande 
moderação - extenso período marcado por um sentimento de segurança na esfera macroeconômica, com elevado crescimento econômico e baixa inflação nos Estados Unidos - não faltavam defensores da idéia de que estávamos caminhando para um novo paradigma da economia mundial.

Na vanguarda dos defensores da idéia que a economia caminhava para um novo patamar estava Alan Greespan, então presidente do Banco Central americano FED - e um grande defensor da desregulamentação financeira. A crença na potencial da Nova Economia1 ${ }^{3}$ - caracterizada por ganhos extraordinários no desempenho, rápido crescimento na produtividade, baixo desemprego e inflação moderada - de aumentar a produtividade elevava as expectativas de lucros, aumentando como conseqüência o preço das ações das empresas.

A partir do final de 1997 os números demonstram o enorme crescimento do investimento e do consumo nos Estados Unidos, fazendo explodir os déficits comerciais e de conta corrente. “[...] em 1999 e de novo em 2000 ambos os déficits como um percentual do PIB estabeleceram novos recordes". (BRENNER, 2003, p. 272). Ambos os déficits mencionados atingiram a cifra próxima de $-4,5 \%$ como percentual do PIB.

O financiamento do déficit americano passou então a depender da poupança de outros países, imprimindo um ritmo forte no avanço do desequilíbrio macroeconômico entre as principais economias do mundo.

Sobre meu ponto de vista [...] é impossível entender a crise sem fazer referência ao desequilíbrio global no comércio e fluxo de capital que começou na segunda metade dos anos 1990s. (BERNANKE, 2009, p.1 $)^{4}$.

$\mathrm{O}$ autor se refere ao desequilíbrio gerado pelo extraordinário excesso de poupança em relação ao investimento que se acumulou em países emergentes, combinado

\footnotetext{
${ }^{3}$ Ver Brenner (2003, p.287)

4"In my view [...] it is impossible to understand this crisis without reference to the global imbalances in trade and capital flows that began in the latter half of the 1990s."
} 
com a deteriorização dos níveis de poupança em relação ao investimento nos Estados Unidos e alguns outros países industrializados.

Como o fluxo da água, poupança fluiu de onde sua presença era abundante para onde existia seu déficit, fazendo com que os EUA e alguns outros países avançados experimentassem forte fluxo de capital entrando no país por mais de uma década, mesmo com a taxa real de juros de longo prazo mantida baixa. (BERNANKE, 2009, p.1) . $^{5}$

[...] O desequilíbrio macroeconômico mundial foi elemento determinante para gestar a crise. Diferentemente dos países desenvolvidos, os emergentes não investiam em empreendimentos no exterior. Tal qual os países exportadores de petróleo nos anos 70 [...] os emergentes também transfeririam seus recursos para o mundo desenvolvido. Em vez de efetuar depósito, compraram papéis públicos [...] (NÓBREGA, 2010, p. 12).

Alan Greespan, chairman do Federal Reserve Board de 1987 à 2006 e grande comandante das finanças pública americana por décadas, não se mostrava reticente com a dinâmica de financiamento dos investimentos americanos.

Os Estados Unidos, como os estrangeiros não hesitam em observar, economizam muito pouco. Nossa taxa de poupança nacional - nada mais que 13,7\% do PIB em 2006 - fizeram os Estados Unidos, de longe, o país desenvolvido que menos poupou. Mesmo incluindo a poupança externa que é investida na economia interna americana, os investimentos totais do país, no nível de $20 \%$ do PIB, foi o terceiro mais baixo entre os grandes países industriais do G7. Porém, como empregamos nossas magras poupanças com muita eficiência e desperdiçamos muito pouco, desenvolvemos um estoque de capital que gerou a mais alta taxa de crescimento da produtividade entre os países do G7 durante quase toda a década passada. (GREESPAN, 2008, p. 356 , grifo meu).

A condição de exportador de capital não era tida como permanente pelos países emergentes. A riqueza financeira funcionava como um colchão para defesa contra

\footnotetext{
5 "Like water seeking its level, saving flowed from where it was abundant to where it was deficient, with the result that the United States and some other advanced countries experienced large capital inflows for more than a decade, even as real long-term interest rates remained low."
} 
eventualidades, sendo assim aplicada em ativos de menor risco e maior liquidez, influenciando a curva de juros de longo prazo, que por sua vez determina o custo do crédito de longo prazo, como financiamento habitacional.

A bolha americana, alimentada por capital externo, não parava de crescer. Em fins de 1999, Greespan chegou a proclamar que "é seguro afirmar estarmos testemunhando, nesta década da história americana, a mais convincente demonstração da capacidade produtiva de povos livres operando em mercados livres". (GRESSPAN, 1999, apud BRENNER, 2003, p. 285).

Meses depois deste pronunciamento - durante o primeiro semestre de 2000 - o índice de Preço/Lucro do Nasdaq atingiu a cifra absurda de 400:1, confirmando o enorme descompasso entre lucro e o preço das ações. Após sair do patamar de USD 4,8 trilhões em 94 e passar para USD 15,7 trilhões em 2000, o valor das ações despencou para USD 10,5 trilhões, ou queda de $33 \%$. A maior escalada no valor das ações concentrou-se no setor de tecnologia, mídia e telecomunicações, setores em que o excessivo investimento se concentrou.

Durante o primeiro semestre de 2000, um e-business depois do outro ficou sem fundos e quebrou, desencadeando o declínio no mercado de valores, e levando à bolha das empresas ponto com em 2001. A maioria desses negócios "jamais tinha visto um centavo de lucro" (BRENNER, 2003, p. 326), e não houve operação de arbitragem capaz de conduzir os preços ao valor fundamental. O resultado foi um excesso de capacidade que ameaçava a economia dos Estados Unidos, trazendo a retração econômica que começou em 2001.

A mini recessão de 2001, agravada pelos ataques terroristas em 11 de setembro, levou a um surto de pânico, contido a penosas reduções de juros por parte do FED. Mais precisamente foram três reduções de taxas de juros em sete semanas, redução que continuou até $1 \%$ de junho de 2003.

Muitos talvez pensaram que a redução de juros seria, em última instância, uma solução universal - amplamente testada - para crises de confiança e liquidez nos mercados. Na crise recente, não apenas os juros americanos foram reduzidos de

\footnotetext{
${ }^{6}$ Ver Brenner (2003, p.321)
} 
5,25\% para praticamente zero, mas vários outros Bancos Centrais fizeram uso da mesma medida.

Como conseqüência das reduções de juros, o consumo interno americano disparou. $\mathrm{O}$ crescente endividamento das famílias norte americanas amparava-se em uma valorização permanente dos ativos adquiridos.

As baixas taxas de juros incentivaram o governo a adotar medidas para ampliar o acesso a casa própria aos americanos de baixa renda. Em 1999, no governo de Bill Clinton, a Fannie Mae - gigante semi-estatal de hipotecas - foi pressionada a ampliar operações. Na seqüência surgiram as chamadas operações de subprime, com taxas de juros que superavam as convencionais.

Em 2002 novas ações - via Fannie Mae (e também via Freddie Mac) - focadas na ampliação dos empréstimos subprimes foram tomadas pelo governo de George W. Bush. No referido ano, Bush sancionou o Single - Family Affordable Housing Tax Credit Act, promovendo incentivos fiscais de US\$ 2,4 bilhões para construção de residências em regiões degradadas.

Essas medidas contribuíram para a queda da qualidade do crédito adquirido das instituições financeiras. As famílias recebiam ofertas de empréstimos exóticos, com baixa exigência de documentação, amortizações negativas nos primeiros anos e outras opções de pagamento que disfarçavam seus riscos. (NÓBREGA, 2010, p. 13).

A expansão do crédito habitacional impulsionava os negócios não apenas do subprime, mas também do mercado prime. Este aumento da demanda por imóveis até então super valorizados - acrescido de taxas de juros baixas que estimulavam a realização de novas hipotecas sobre o mesmo imóvel - formava o cenário adequado para formação de uma bolha nos preços.

A crise financeira geral partiu da crise dos "subprimes", ou, mais precisamente, de hipotecas oferecidas a clientes de qualidade de crédito inferior que eram depois agrupadas em títulos complexos e opacos cujo risco associado era de avaliação difícil, senão impossível, para os compradores. (BRESSER, 2010, p.53). 
O cenário formado por juros baixos, propiciando o aumento da demanda por imóveis por meio de fácil acesso a financiamento, acrescido de um movimento de instituições financeiras no sentido de empacotar milhares de hipotecas, transformando-as em instrumentos securitizáveis nos mercados financeiros globais, gerou o cenário da crise.

Somado ao endividamento doméstico ocorria o endividamento americano como nação, ou seja, a dívida externa americana não parava de crescer. Em 2006 o déficit externo americano atinge seu ápice, chegando a 6\% do PIB, ou US\$ 800 bilhões (SILBER, 2010).

Em 2008 a crise se instalou, aniquilado empresas tradicionais durante o quarto trimestre de 2008 e parte do ano de 2009, na esteira do pedido de recuperação judicial do quarto maior banco americano, o Lehman Brothers, em 15 de setembro de 2008 - seu momento mais grave.

As extensões da crise não ficaram restringidas apenas ao mercado americano, atingindo empresas no mundo inteiro. Conseqüências e desdobramentos da crise ainda estão presentes na esfera econômica mundial.

Assim, a recente crise financeira que assolou o mundo em meados de 2008 definitivamente não foi um evento qualquer. Na verdade foi uma grande catástrofe comparável ao crash de 1929. Se hoje não falamos da segunda grande depressão é graças à maciça intervenção dos bancos centrais e dos tesouros no resgate da economia.

Quais seriam as causas da atual crise? Há algumas perguntas crucias que surgem em meio ao debate sobre as razões que geraram a crise. Questões como: o que aconteceu fora do padrão esperado? Havia falhas nos modelos de prevenção de risco ou as premissas em que eles se baseavam é que não eram realistas? $\mathrm{O}$ problema foi falta de regulação ou falta de aplicação das regras propostas? Faltou supervisão para a aplicação das regras anteriormente definidas? Fugindo do debate idealista, a questão crucial para o momento é aprender com os erros e analisar o que pode ser feito no futuro.

$\mathrm{Na}$ esfera das transações bancárias, problemas clássicos como o risco moral, risco de agência, ou a assimetria de informações são intrínsecos às operações, tanto na 
esfera pública quanto na privada. Um dos principais objetivos da regulação é justamente minimizar os efeitos destes riscos, criando condições igualitárias para os diferentes agentes de mercado. Cabe a regulação prudencial garantir a preservação da estabilidade e solidez do sistema bancário.

Como forma de garantir padrões de comportamento, distintos instrumentos de supervisão e controle são criados, garantindo que as operações mantenham o risco das operações em patamares toleráveis não apenas para os envolvidos diretamente nas transações, mas sobretudo para a economia local e internacional.

Essas regras podem envolver fatores relativos ao nível de disclosure de informações, exigência mínima de capital próprio adequado ao nível de risco dos ativos em carteira, credenciamento e avaliações periódicas das instituições, mecanismos de proteção aos investidores. Além disso, envolvem o processo de restrição à concorrência, com regras claras e avaliação pertinente de operações de aquisição e fusão de empresas, fiscalizando seu impacto na competitividade do mercado.

Mas apesar de todo aparato prudencial, na essência, sabemos que há questões relacionadas à natureza humana. Durante os anos de prosperidade, muitos economistas dedicados a analisar o ambiente financeiro chegaram a acreditar que mercados são, inerentemente, estáveis. E que ações e outros tipos de ativos eram sempre precificados corretamente. Modelos de previsão não sugeriam que algum tipo de colapso aconteceria em 2008 (KRUGMAN, 2009, p.1-2). O que estaria errado?

Krugman (2009) ressalta que, nos anos 70, a discussão acadêmica em torno de questões relacionadas à irracionalidade dos investidores, especulação destrutiva e formação de bolhas, havia desaparecido. A clássica visão de Keynes sobre o mercado financeiro funcionando como um cassino havia sido substituída pela Hipótese de Mercados Eficientes (HME), promulgada por Eugene Fama da Universidade de Chicago. Seria essa proposição então ainda válida?

Em meio a tantos questionamentos, a crise trouxe a tona uma calorosa discussão a respeito da eficácia das medidas regulatórias existentes, e da conseqüente necessidade de um acirramento e aperfeiçoamento da regulação e supervisão 
financeira, incrementando o nível atual de regulação e limitando a liberdade de ações dos agentes financeiros.

Por outro lado, o risco de com isso promover a volta do uso de práticas econômicas que pouco estimulem a evolução e desenvolvimento de mercados parece não ser um desejo da sociedade. $\mathrm{O}$ adequado equilíbrio destas variáveis parece ser fundamental para evitar riscos futuros, permitindo a evolução dos mercados de forma sólida e robusta.

\subsection{O Problema de pesquisa}

O movimento de gradual desregulamentação do mercado financeiro, a partir da década de 1970, promoveu um maior grau de liberdade operacional aos bancos. Como conseqüência, houve o aumento dos riscos das operações, fator que levou a ocorrência de sucessivas crises. As mais relevantes acarretaram na falência do Herstatt Bank na Alemanha e do Franklin National nos Estados Unidos, ambas no ano de 1974. Surge então um movimento no sentido de promover uma "reregulamentação" (CORAZZA, 2005, p. 85).

Assim, em 1975, há a criação do Comitê de Supervisão Bancária da Basiléia - ou simplesmente BCBS, da sigla em inglês Basel Committe on Banking Supervision entidade criada pelos bancos centrais representantes dos países do G10 (grupo dos Dez).

Em 1988, os países do G10, reunidos no BCBS, acordarem e divulgaram em 1988 o acordo de Basiléia I, transformando em uma norma regulatória a exigência de capital para todos os competidores que operassem nas jurisdições dos países que fizessem parte do Acordo.

O problema é que o acordo não era abrangente suficiente a ponto de englobar mercados como o de derivativos e securitização de recebíveis.

Em 2004 um novo Acordo - Acordo de Basiléia II - oficialmente denominado "Estrutura Revisada para o Capital Internacional" (Revised International Capital Framework) trouxe novas modificações quanto ao tratamento de riscos financeiros, 
desenvolvendo um maior detalhamento de classes de riscos de crédito e de mercado, e agregando um componente de avaliação de risco operacional.

Pelo novo cálculo, o capital regulatório mínimo exigido deve ser maior ou igual a $8 \%$ dos ativos ponderados pelo risco. A alavancagem máxima do patrimônio líquido em relação aos ativos ponderados pelo risco é o inverso deste número, ou seja, 12,5 vezes. No caso Brasileiro o Banco Central foi ainda mais rigoroso, exigindo que o capital seja de no mínimo $11 \%$ dos ativos ponderados pelo risco.

Apesar dos esforços empenhados em elaborar uma regulação prudencial mais consistente, os mercados financeiros do mundo todo foram contaminados por uma das maiores crises da estória - a mais intensa depressão financeira desde a Grande Depressão de 1929. Nas palavras do atual chairman do Fed, em seu discurso proferido no Simpósio Econômico Anual do Federal Reserve Bank, em 21 de agosto de 2009:

Desde a última vez que nos encontramos aqui, o mundo passou pela mais severa crise financeira desde a Grande Depressão. A crise deflagrou uma profunda depressão global, da qual estamos apenas começando a emergir agora (...) Olhando para a frente, devemos urgentemente cuidar das vulnerabilidades estruturais do sistema financeiro, em particular aquelas relacionadas à estrutura regulatória, para garantir que não tenhamos novamente de incorrer nos enormes custos dos últimos anos. (BERNANKE, 2009, apud MORANDI, FIRMO, 2009, p.29).

Mas, de maneira irrefutável, é possível afirmar que regulação prudencial foi desenvolvida nos anos anteriores a crise. Então o que aconteceu? A regulação foi errada, incompleta ou não aplicada?

As palavras de Bernanke resumem o sentimento geral que paira sobre estudiosos, executivos, banqueiros e sociedade de uma forma geral. Há uma sensação que algo deixou de ser feito, e paira sobre a regulação grande parte dessa espécie de frustração social que teria acabado com os anos dourados. 
A crise global de 2008 começou como costumam começar as crises financeiras em países ricos e foi causada pela desregulação dos mercados financeiros e pela especulação selvagem que essa desregulação permitiu. A desregulação foi o fato histórico novo que abriu as portas para a crise. (BRESSER, 2010, p.52).

Mas a questão da regulação não é ponto pacifico. Para Stiglitz (2009), a solução para redução do risco relacionado às instituições financeiras ocorrerá com duas medidas: aplicar um rígido regime regulatório, mas ao mesmo tempo dividindo as instituições "grandes demais para quebrar", "grandes demais para gerenciar" e "grandes demais para socorrer" em operações menores.

Stiglitz (2009) fundamenta seu argumento na idéia que algumas instituições financeiras cresceram demasiadamente, tornando-se assim "too big to fail" - uma posição que segundo o autor aumenta a propensão de tomada de risco, já que existe a garantia que o contribuinte pagará a conta por um eventual resultando adverso. "A primeira lição de economia é que incentivos importam. Quando há incentivos perversos, há resultados perversos." (STIGLITZ, 2009, p.5).

Galbraith (1993) parte de uma análise comportamental, afirmando que depois de uma crise especulativa, fala-se muito em reformas e regulação, mas pouco se fala sobre a especulação em si, e o "aberrant optimism" que esteve por trás da alta dos preços. Para o autor, a regulação não poderá agir sobre a euforia em massa que gerou o processo especulativo. Assim, somente um maior ceticismo, que associe o excesso de otimismo a uma insensatez momentânea, poderia remediar os males dos processos irracionais de alta de preços.

Para Grout, Zalewska (2005), empresas que sofrem um alto nível de regulação direta e indireta são algo entre uma empresa estatal e uma empresa privada. Melhorias operacionais dos mercados podem surgir com o acirramento da normatização, mas a possibilidade das autoridades reguladoras intervirem a qualquer momento pode trazer riscos maléficos, como o não cumprimento de contratos.

\footnotetext{
7 "The first lesson of economics is that incentives matter. When there are perverse incentives, there are perverse outcome.s"
} 
Assim, entender como a regulação impacta o risco dessas empresas é fundamental para escolhas de portfólios e desenho de políticas estratégicas, dado que há aspectos positivos e negativos envolvidos na aplicação de uma nova política restritiva. Nesse sentido é crucial entender o impacto de mudanças regulatórios no risco dos bancos afetados.

Referindo-se especificamente ao Brasil, há um consenso geral que, após analisar o efeito da crise financeira de 2008, o arcabouço regulatório criado no país desde a última década do século passado parece ter sido relativamente eficaz para lidar com a crise, certamente revelando-se mais eficaz do que a normatização existente em outros países - mesmo aqueles tidos como mais desenvolvidos. Mas houve de fato uma redução do risco das instituições financeiras no país?

\subsection{Objetivos}

O objetivo central deste trabalho é estudar o impacto da regulação bancária brasileira, advinda da regulação internacional e desenvolvimento dos Acordos de Basiléia, no risco das instituições financeiras no Brasil.

Dessa forma, o presente trabalho pretender responder a seguinte questão:

- O nível de risco das instituições financeiras atuantes no Brasil foi alterado com a introdução da regulação prudencial no país?

\subsection{Aspectos metodológicos}

Segundo Marconi e Lakatos (2005, p.83) método é o “conjunto das atividades sistemáticas e racionais que, com maior segurança e economia, permite alcançar o objetivo [...] traçando o caminho a ser seguido, detectando erros e auxiliando as decisões dos cientistas".

A metodologia escolhida para este trabalho será o estudo de evento, que consiste em avaliar o comportamento de uma variável qualquer a partir de um evento 
específico, analisando se de fato o evento ocorrido gerou algum desvio no resultado esperado.

Segundo Campbell, Lo e Mackinley (1997) o estudo de evento é o método pelo qual, utilizando-se dados do mercado financeiro, é possível medir o efeito de um evento específico no valor de uma determinada empresa.

Tal efeito é esperado em função da premissa de racionalidade do mercado, o que implica que o efeito de um evento será refletido imediatamente nos preços dos ativos.

Mackinley (1997) ressalta que a metodologia do estudo de evento possui inúmeras aplicações em estudos na área de finanças e contabilidade, sendo aplicado na análise de uma grande variedade de eventos relacionados à empresas ou a alterações na economia, como operações de fusões e aquisições, divulgação de resultados, emissão de dívida ou equity, anúncio de variáveis macro econômicas como evolução de déficits comerciais - e avaliação do impacto de mudanças no ambiente regulatório sobre uma firma.

O imediatismo esperado na assimilação da informação permite que a mensuração do impacto econômico seja feita em um espaço de tempo relativamente curto, configurando-se uma vantagem interessante em termos de método, já que a análise não requer dados extensos como outros tipos de metodologia.

Embora não haja uma única estrutura para condução de um estudo de evento, este trabalho segue o procedimento elaborado por Campbell, Lo e Mackinley. Os autores buscaram em dois trabalhos - Mackinley (1997) e Campbell, Lo e Mackinley (1997) - a padronização dos procedimentos para condução de um estudo de evento.

Os autores determinam sete principais passos para a execução da metodologia de estudo de evento:

1. Definição do evento, e do período em que se aplica sua influência;

2. Estabelecimento de critérios de seleção da amostra;

3. Medição do retorno amostral; 
4. Estabelecimento de procedimentos de estimação (seleção do teste estatístico);

5. Definição de procedimentos de teste (definição de hipóteses);

6. Apresentação dos resultados empíricos;

7. Interpretação e conclusões;

As hipóteses de pesquisa e demais etapas da metodologia utilizada no trabalho estão detalhadas no capítulo 5.

\subsection{Descrição dos capítulos}

Este estudo está dividido em sete capítulos $\mathrm{O}$ primeiro capítulo é dedicado à apresentação do problema de pesquisa e objetivos do trabalho, bem como à descrição da metodologia de pesquisa a ser utilizada. O capítulo 2 apresenta o conceito de risco sob a ótica da moderna teoria de finanças, detalha a hipótese de mercados eficientes (HME) e faz um contraponto à referida tese, apresentando os conceitos relacionados às distorções à hipótese da racionalidade - a chamada finanças comportamentais. Por último, o capítulo 2 relaciona o conceito da regulação como forma de mitigação das distorções e ineficiências de mercado. $\mathrm{O}$ capítulo 3 descreve a evolução da regulação prudencial voltada para bancos no mundo, enquanto que o capítulo 4 é dedicado a detalhar a evolução da regulação prudencial no Brasil. O capítulo 5 apresenta as hipóteses que serão testadas e a metodologia de pesquisa utilizada para testá-las. O capítulo 6 apresenta os resultados dos testes e as análises dos resultados observados. Finalmente, o capítulo 7 trata das considerações finais do trabalho. 


\section{FUNDAMENTAÇÃO TEÓRICA}

\subsection{A Moderna teoria de finanças e o risco}

\subsubsection{A Teoria de Carteiras de Markowitz e as Decisões em Condições de Risco} Os primeiros estudos sobre as preferências de risco dos investidores e a tomada de decisão sobre incerteza surgiram apenas na década de 1940 e 1950, com destaque para os trabalhos de Von Neumann e Morgenstern (1944) e Savage (1954).

A partir da década de 50 surgem os primeiros trabalhos relacionados à teoria da carteira, os quais desenvolveram modelos com o objetivo de gerar portfólios que apresentassem uma relação adequada entre risco e retorno, balanceando de forma ótima o trade off entre essas duas variáveis.

Neste contexto, surge um dos modelos mais notórios sobre a teoria da carteira, proposto por Harry Markowitz em seu trabalho pioneiro - Portfolio Selection - de 1952, inaugurando as bases da chamada moderna teoria de finanças. A contribuição do autor, aluno de Savage na universidade de Chicago, foi preponderante para evolução do estudo do impacto do risco nas decisões de investimento, formulando um modelo que identifique a melhor escolha sobre determinadas condições de risco e preferências pessoais.

O modelo trabalha a hipótese de que a relação risco e retorno de um conjunto de ativos com risco é otimizada por meio da diversificação dos ativos. Esse processo de diversificação reduz o risco específico a cada empresa da carteira, na medida em que o capital será aplicado em títulos de diferentes companhias, formando com isso uma carteira eficiente. "A análise de portfolio começa com informação a respeito de ativos individuais. $\mathrm{O}$ processo termina com conclusões a respeito de portfólios como um todo. O propósito da análise é encontrar portfólios que melhor se encaixem aos objetivos do investidor." (MARKOWITZ, 1959, p.3) ${ }^{8}$.

\footnotetext{
8 "A portfolio analysis starts with information concerning individual securities. It ends with conclusions concerning portfolios as a whole. The purpose of the analysis is to find portfolios which best meet the objectives of the investor."
} 
Em condições de risco, o investidor não pode associar um único resultado, ou payoff, ao investimento. Todos os possíveis resultados, ponderados por suas respectivas probabilidades de ocorrência, devem ser considerados na tomada da decisão, reduzindo a incerteza.

Um investidor que conheça retornos futuros com precisão iria investir em somente um ativo, que seria aquele com maior retorno esperado [...] Em nenhum caso o investidor iria de fato optar por um portfólio diversificado. Mas a diversificação é uma prática de investimento comum e razoável. Porque? Para reduzir incerteza! Claramente, a existência de incerteza é essencial para a análise do comportamento do investidor racional. (MARKOWITZ, 1991, p.469, grifo meu $)^{9}$.

Nesse sentido, o modelo proposto por Markowitz contribuiu para a consideração do risco na análise e seleção de investimentos ao formular um modelo teórico que permitia ao investidor tomar a melhor decisão em condições de risco, baseado em suas preferências pessoais de propensão a risco e expectativa de retorno.

Segundo Markowitz (apud ELTON, GRUBER, 2004) investidores consideram a distribuição de probabilidade das alternativas de investimentos para tomar decisões em relação ao perfil de sua carteira de investimento. A partir destas distribuições de probabilidades, Markowitz (1952, p.79) estabelece critérios de seleção dos ativos baseados no retorno e risco, representados respectivamente pela média e pela variância dos ativos que compõem a carteira.

A média, ou retorno esperado, é calculada da seguinte forma:

$$
E\left(\tilde{R}_{i}\right)=\bar{R}_{i}=\sum_{j=1}^{M} P_{i j} R_{i j}
$$

\footnotetext{
9 "An investor who knew future returns with certainty would invest on only one security, namely the one with highest future return [...] In no case would the investor actually prefer a diversified portfolio. But diversification is a common and reasonable investment practice. Why? To reduce uncertainty! Clearly, the existence of uncertainty is essential to the analysis of rational investment behavior."
} 
Sendo,

$E\left(\tilde{R}_{i}\right)_{\text {: retorno esperado de }} R_{i j}$

$P_{i j}$ : probabilidade de retorno do ativo i;

$R_{i j}$ : resultado possível em termos do retorno do ativo i;

Já o risco é representado pela variância - $\sigma^{2}$ - é calculado da seguinte maneira:

$$
\sigma^{2}\left(\tilde{R}_{i}\right)=\sigma_{i}^{2}=\sum_{j=1}^{M}\left[P_{i j}\left(R_{i j}-E\left(\tilde{R}_{i}\right)\right)^{2}\right]
$$

O autor expressa especial atenção quanto ao tipo de informação utilizada como matéria prima para a análise de portfólio.

Muitos tipos de informação a respeito de um ativo podem ser utilizadas como matéria prima para uma análise de portfólio. Uma fonte de informação é a performance histórica de ativos específicos. Uma segunda fonte de informação é a crença de um ou mais analistas de ação a respeito de performance futura. (MARKOWITZ, 1959, p.3) ${ }^{10}$.

O autor, porém, ressalta que, quando informações sobre performance passada de um ativo são utilizadas como inputs, será gerado um portfólio com boa performance no passado, mas não necessariamente no futuro.

Seleção de portfólio deve ser baseada em crenças razoáveis sobre o futuro ao invés de performance passada por si só. Escolha baseada somente em performance passada assume, efetivamente, que retornos médios do passado são boas estimativas do retorno futuro; e que a

\footnotetext{
10 "Various types of information concerning securities can be used as the raw material of a portfolio analysis. One source of information is the past performance of individual securities. A second source of information is the beliefs of one or more security analysts concerning future performances."
} 
variabilidade do retorno no passado é um boa medida da incerteza do retorno no futuro. (MARKOWITZ, 1959, p.14) ${ }^{11}$.

Como é possível notar, a análise de ativos isoladamente é uma arte que exige previsões sobre o desempenho futuro dos ativos de uma economia, notadamente a incerteza e o retorno esperado do ativo (Sharpe, 1970, p. 32). O resultado desta análise deve servir de input para a análise de carteiras, que busca gerar previsões sobre o desempenho futuro de carteiras formadas por ativos de natureza distinta.

Uma carteira p composta por dois ativos, a e b, na proporção de x e (1-x) respectivamente, tem o seguinte retorno esperado:

$$
E\left(\tilde{R}_{p}\right)=x E\left(\tilde{R}_{a}\right)+(1-x) E\left(\tilde{R}_{b}\right)
$$

onde,

$x$ : proporção da carteira aplicada no ativo a;

(1-x): proporção da carteira aplicada no ativo b;

$E\left(\tilde{R}_{p}\right)$ : retorno esperado da carteira;

$E\left(\tilde{R}_{a}\right)$ : retorno esperado do ativo a;

$E\left(\tilde{R}_{b}\right)$ : retorno esperado do ativo b;

Já o risco da carteira formada pela combinação de ativos não corresponde a uma média ponderada dos riscos dos ativos individuais, sendo influenciado por uma medida de como os retornos dos ativos variam em conjunto. Esta medida é o coeficiente de correlação dos retornos dos ativos a e b, conforme indicado na expressão a seguir.

11 "Portfolio selection should be based on reasonable beliefs about future rather than past performance per se. Choice based on past performances alone assume, in effect, that average returns of the past are good estimates of the "likely" return in the future; and variability of return in the past is a good measure of the uncertainty of return in the future." 


$$
\sigma^{2}\left(\tilde{R}_{p}\right)=\sigma_{p}^{2}=x^{2} \sigma_{a}^{2}+(1-x)^{2} \sigma_{b}^{2}+2 x(1-x) \rho_{a, b} \sigma_{a} \sigma_{b}
$$

Onde,

$\sigma_{p}^{2}=$ variância da carteira $\mathrm{p}$ formada pelos ativos a e b;

$\sigma_{a}^{2} \mathrm{e}^{\sigma_{b}^{2}}=$ variância dos ativos a e b, respectivamente;

$\rho_{\mathrm{a}, \mathrm{b}}=$ coeficiente de correlação entre os ativos a e b;

O coeficiente de correlação varia entre +1 (valor máximo) e -1(valor mínimo). Assumindo que a correlação dos dois ativos, a e b, seja perfeita e positiva, igual a +1 , substituindo este valor em (2.4):

$$
\sigma_{p}^{2}=\left[x_{a}^{2} \sigma_{a}^{2}+(1-x)^{2} \sigma_{b}+2 x(1-x) \sigma_{a} \sigma_{b}\right]=\left[x \sigma_{a}+(1-x) \sigma_{b}\right]^{2},
$$

ou

$$
\sigma_{p}=x \sigma_{a}+(1-x) \sigma_{b}
$$

A análise da equação (2.5) mostra que, quando os retornos dos ativos são perfeitamente correlacionados, ou seja, $\rho_{\mathrm{a}, \mathrm{b}}=1$, o risco e o retorno da carteira composta pelos dois ativos são calculados como médias ponderadas dos retornos e dos riscos de cada um dos ativos. "Não há redução de risco com a compra dos dois ativos”. (ELTON, GRUBER, 2004, p. 81). A análise do gráfico 1 permite visualizar a situação descrita. 


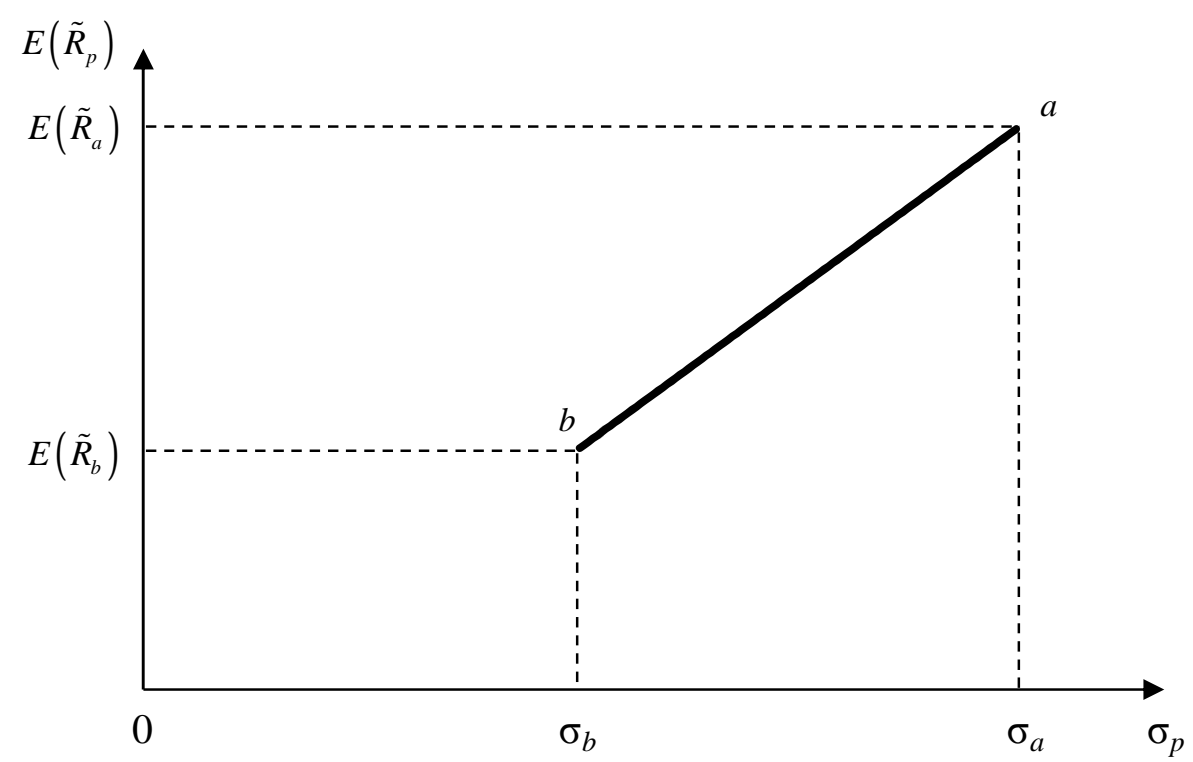

Gráfico 1 - Relação entre retorno esperado e risco da carteira, para $\rho=1$

Já para uma situação em que o coeficiente correlação dos retornos é igual a -1, ou seja, o retorno dos ativos a e b variam perfeitamente em conjunto, mas em direções opostas, há possibilidade de diversificação eficaz da carteira. Neste caso a diversificação é particularmente útil dado que algumas combinações de ativos fornecerão um risco inferior ao inerente a cada ativo analisado individualmente. Importante ressaltar que na situação de $\rho_{a, b}=-1$, a relação entre o risco da carteira p e ainda é linear, conforme demonstra o gráfico 2: 


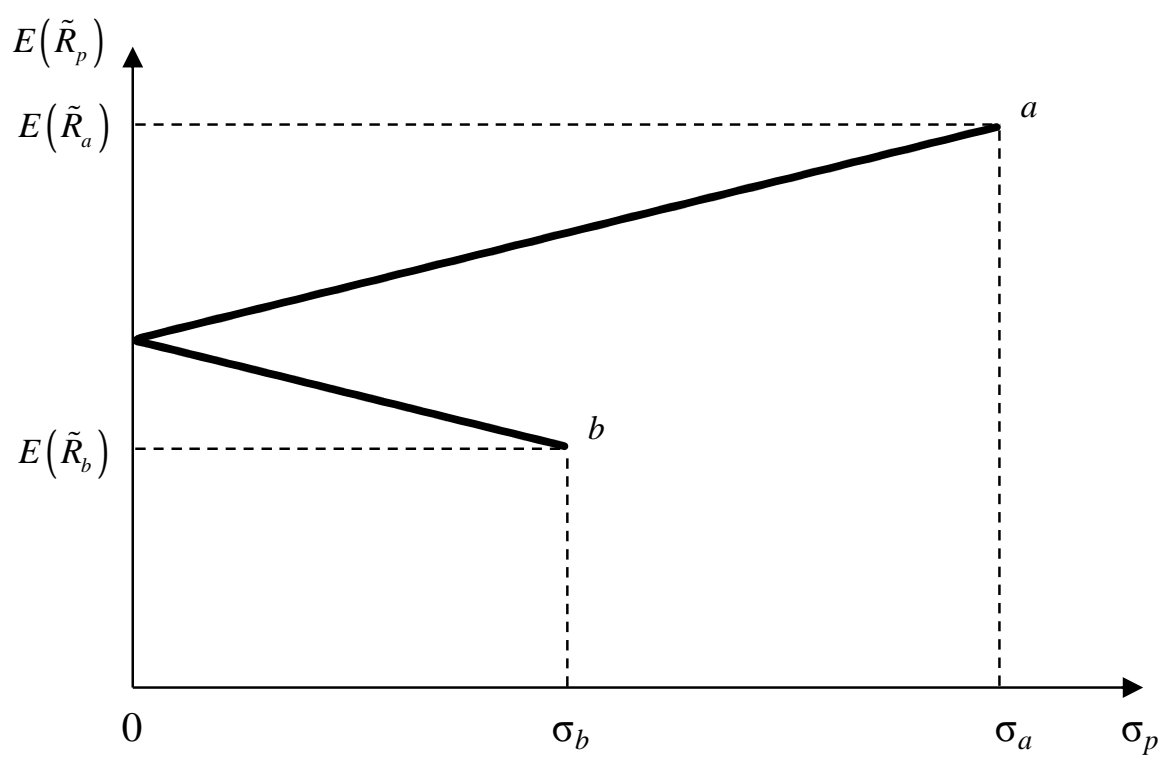

Gráfico 2 - Relação entre retorno esperado e risco da carteira, para $\rho=-1$

Quando a correlação entre os retornos é distinta dos valores de coeficiente de correlação máximo e mínimo, a relação entre o risco da carteira p e as proporções de a e b deixa de ser linear, gerando uma curva de possibilidades de combinação de ativos, conforme o gráfico 3.

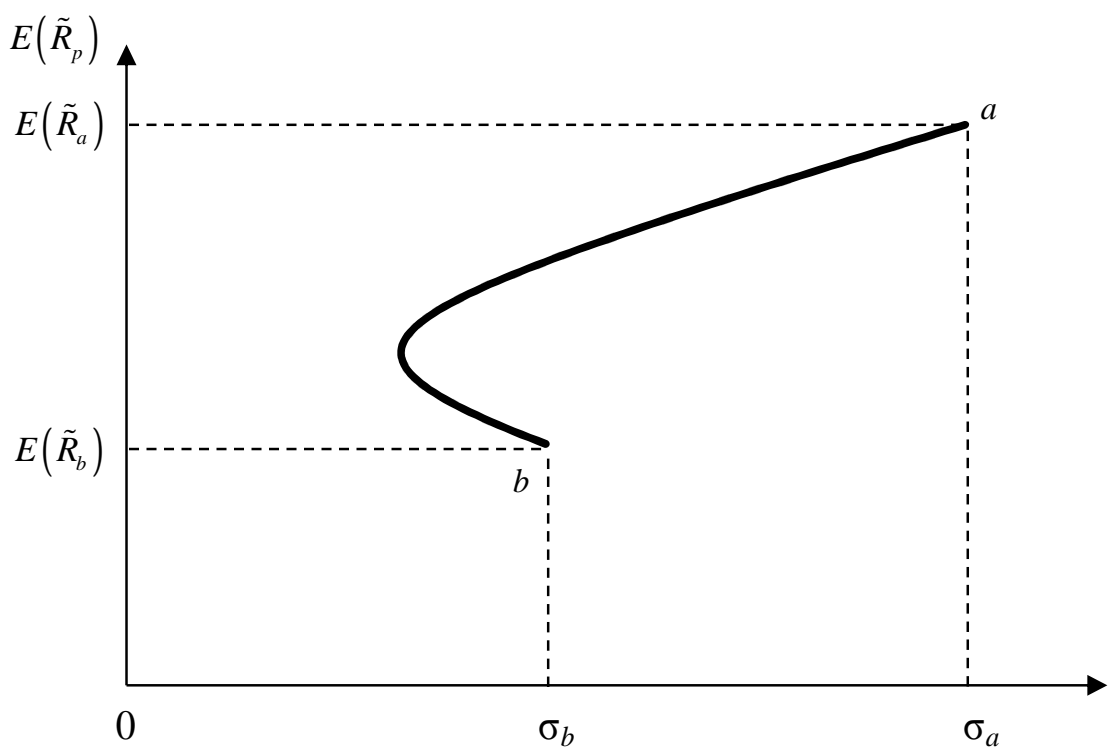

Gráfico 3 - Relação entre retorno esperado e risco da carteira para $\rho<1$ e $\rho>-1$ 
O Gráfico 4 demonstra todas as possíveis combinações de ativos a e b e as respectivas estratégias de diversificação de risco que podem surgir variando o coeficiente de correlação dos ativos. Estas possíveis estratégias são as chamadas Curvas de Oportunidade, e estão representadas nos segmentos acb, adb e ab.

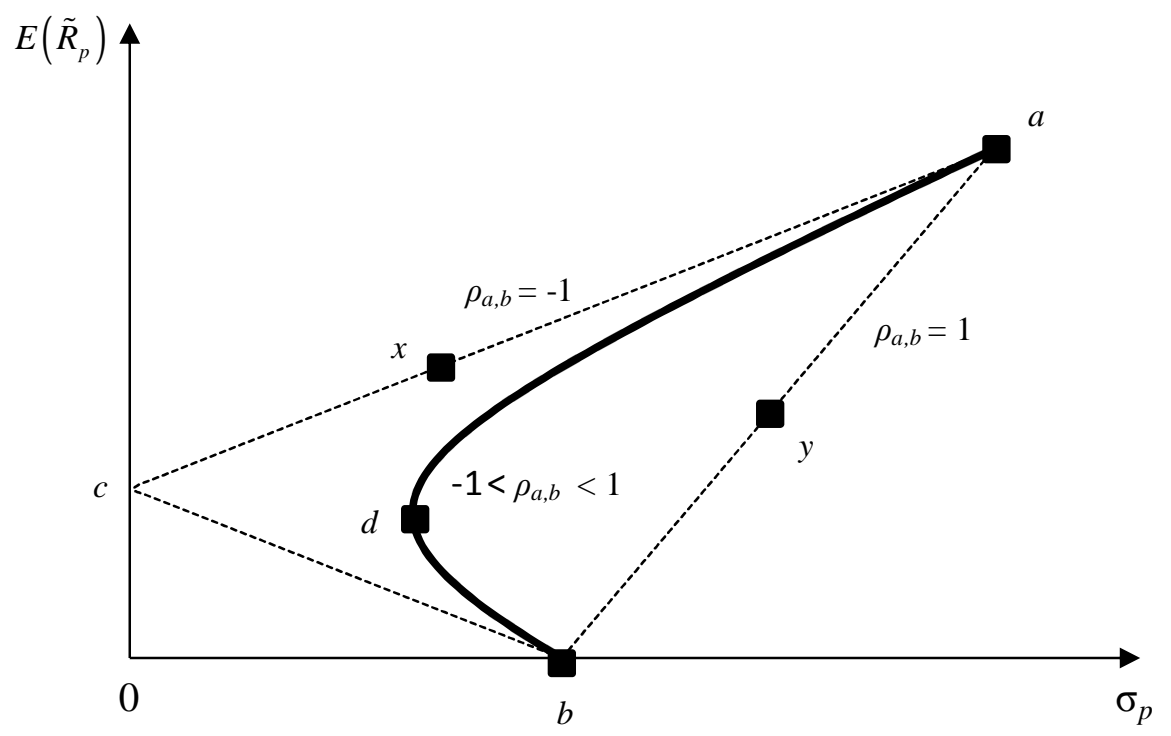

Gráfico 4 - Curvas de oportunidade para a carteira formada pelos ativos a e b

Generalizando o modelo para $n$ ativos, a curva de oportunidades torna-se a fronteira de uma área compacta, contendo todas as possíveis combinações de carteira. Esta fronteira é a chamada Fronteira Eficiente.

Vale ressaltar que, de acordo com o modelo, Markowitz tratava do investidor e de suas decisões de investimento de forma individual. $\mathrm{E}$ as melhores decisões para este investidor estariam situadas sobre a chamada Fronteira Eficiente.

A criação da chamada carteira eficiente proporcionaria ao investidor retornos ótimos para um dado nível de risco. Para chegar a este resultado, o modelo apontava que investidores poderiam eliminar algum tipo de risco, mas não todo tipo de risco, ao manter um portfólio diversificado (PEROLD, 2004, p.6).

Porém, mesmo que o investidor diversifique a aplicação de seus recursos de maneira eficiente, ainda existe o risco relacionado com o contexto econômico como um todo. Esse risco, chamado risco sistêmico - e medido pelo beta - pode comprometer a taxa de retorno que o aplicador de recursos espera obter sobre 
determinado ativo. O modelo CAPM estendeu a teoria do portfólio ao introduzir as noções do risco sistemático ao modelo.

\subsubsection{Tratamento do Risco Sistêmico - O modelo do CAPM}

Baseado nos estudos de Markowitz (1952), o Modelo de Precificação de Ativos de Capital ou Capital Assets Pricing Model - CAPM - foi desenvolvido por Treynor (1961) e Sharpe (1964; 1970), com posteriores contribuições de Mossin (1966) e Lintner (1965).

O CAPM - que trata do comportamento conjunto dos investidores na precificação dos ativos em um mercado - representa o retorno esperado de um investimento que conduz a uma situação de equilíbrio, não havendo, portanto, espaço para arbitragem. $\mathrm{Na}$ prática, o CAPM representa a taxa esperada de retorno que investidores exigiriam de determinado ativo.

Importante ressaltar que o CAPM estabelece uma relação linear entre risco e retorno. O CAPM decompõe o risco de portfólio em risco sistemático - e portanto não diversificável - e risco específico - aquele não correlacionado com as movimentações do mercado. Supondo a existência de portfólios completamente diversificados, o risco total do portfólio - único tipo de risco passível de remuneração - é igual ao seu nível de risco sistemático.

Nos estudos de Sharpe, o CAPM foi desenvolvido como parte da Teoria do Mercado de Capitais - que por sua vez reflete a teoria do portfólio desenvolvida previamente por Markowitz.

Em geral o termo teoria do portfólio será usado para se referir à abordagem normativa [guia para ação] e o termo teoria do mercado de capitais para se referir a abordagem positive [descreve a maneira em que uma decisão é tomada]. No entanto, a diferença é prioritariamente o uso em que a teoria é colocada. Há somente um modelo básico. (SHARPE, 1970, p. 3) ${ }^{12}$.

\footnotetext{
12 "In general the term portfolio theory will be used to denote the normative approach [guide to action] and the term capital market theory to denote the positive approach [ describes the manner in which decisions are made]. However, the difference is primarily in the use to which the theory is put. There is only one basic model."
} 
A teoria do mercado de capitais assume que (SHARPE, 1970, p.77) :

a. Investidores tomam decisões baseados em expectativas sobre a performance futura de ativos. Tais expectativas se referem ao retorno esperado, desvio padrão dos retornos e coeficiente de correlação das taxas de retorno;

b. Investidores possuem carteiras diversificadas da forma apresentada pela teoria de Markowitz;

c. Existência de uma taxa livre de risco na economia (chamada por Sharpe de pure rate of interest), idêntica para todo investidor, e que pode ser utilizada para aplicação ou captação de recursos, sem limitação de quantidade disponível;

Sharpe (1970) então ressalta que, considerando um investidor - qualquer investidor - e dado as previsões sobre os ativos com risco, dado a taxa livre de risco, e dado a possibilidade de emprestar e tomar emprestado à uma taxa livre de risco, o investidor encontrará uma situação similar a demonstrada no gráfico 5.

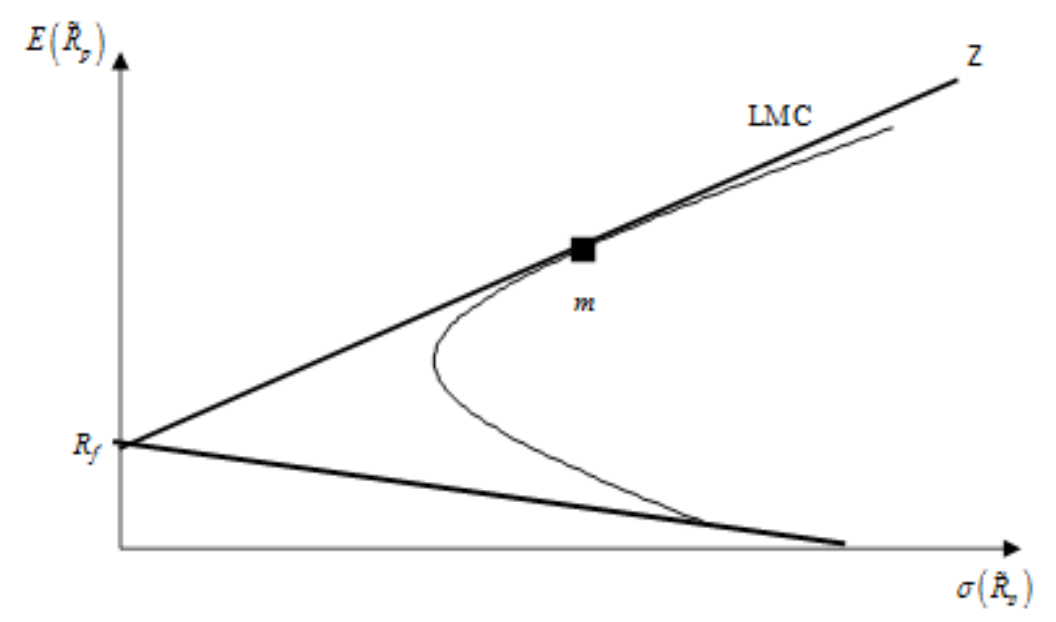

Gráfico 5 - Fronteira Eficiente e a Linha de Mercado de Capitais

Todos portfólios eficientes se situam sobra uma reta como $\mathrm{R}_{\mathrm{f}} \mathrm{MZ}$. Cada ponto sobre a reta pode ser obtido ao (1) emprestar ou tomar emprestado a taxa livre de risco (ou ambos) e (2) alocando parte da carteira em uma parcela arriscada referente ao portfólio $m$, composto inteiramente por ativos com risco. 
O portfólio $m$ indica, dessa forma, a composição ótima de ativos com risco. Em equilíbrio, a combinação ótima de ativos com risco deve incluir todos os ativos, na proporção referente à sua participação no valor de mercado de todos os ativos com riscos existentes. Esta combinação ótima de ativos com riscos foi chamada por Sharpe (1970) de Carteira de Mercado. "O portfólio de mercado (por definição) inclui somente ativos com risco." (SHARPE, 1970, p. 82) ${ }^{13}$.

Em equilíbrio, qualquer investidor optará por uma carteira situada sobre a linha $\mathrm{R}_{\mathrm{f}} \mathrm{MZ}$, denominada por Sharpe (1970) de Linha de Mercado de Capitais (Security Market Line).

O CAPM implica que todos ativos e portfólios irão se situar em uma linha como essa [Linha de mercado de capitais]. Muitos argumentariam que esta relação é a mais importante conclusão derivada do CAPM. Isto mostra que o retorno esperado apresentará uma relação linear à risco de mercado, mas não, como comumente se acredita, ao risco total. $\left(\right.$ SHARPE, 1991, p. 496) ${ }^{14}$.

Todos os investidores acabarão com carteiras situadas em algum ponto da linha de mercado de capitais, e todas as carteiras eficientes se encontrariam na linha de mercado de capitais. Na verdade, com base na construção da carteira eficiente, sabemos que todas as carteiras de ativos com risco e sem risco, exceto aquelas que são eficientes, estão situadas abaixo da linha de mercado de capitais. (ELTON, GRUBER, 2004, p.264).

Partindo do risco nulo $\left(\mathrm{R}_{\mathrm{f}}\right)$, correspondente ao ativo livre de risco, o nível de risco da carteira varia conforme o incremento da porcentagem da composição da carteira alocada na carteira de mercado. Assim, o que muda é a percentagem alocada em ativos com risco, e não a composição da carteira de mercado (parcela arriscada).

\footnotetext{
13 "The market porfolio (by definition) includes only risky securities."

14 "The CAPM implies that all securities and portfolios will plot along such a line [Security Market Line]. Many would argue that this relationship is the most important single conclusion derived from the CAPM. It shows that expected returns will be linearly related to market risk, but not, as often believed, to total risk."
} 
Dessa forma, analisando o gráfico 5, é possível notar que o retorno esperado da carteira formada pela combinação de ativo livre de risco $\left(R_{f}\right)$ na proporção $W_{1}$ e da carteira de mercado na proporção $\mathrm{W}_{2}$ é dado por:

$$
\mathrm{E}\left(\widetilde{\mathrm{R}_{\mathrm{p}}}\right)=\mathrm{W}_{1} \mathrm{R}_{\mathrm{f}}+\mathrm{W}_{2}\left[\mathrm{E}\left(\widetilde{\mathrm{R}_{\mathrm{m}}}\right)\right]
$$

Sendo:

$\mathrm{E}\left(\widetilde{\mathrm{R}_{\mathrm{p}}}\right)=$ retorno esperado da carteira $\mathrm{p}$

$\mathrm{W}_{1}=$ parcela percentual de recursos aplicada na taxa livre de risco;

$\mathrm{R}_{\mathrm{f}}=$ taxa de retorno do ativo livre de risco;

$\mathrm{W}_{2}=$ parcela percentual de recursos aplicada na carteira de mercado;

$\mathrm{E}\left(\widetilde{\mathrm{R}_{\mathrm{m}}}\right)=$ retorno esperado da carteira de mercado;

E o risco dessa carteira, por sua vez, é dado por:

$$
\sigma\left(\widetilde{R_{p}}\right)=\sqrt{W_{1}^{2} \sigma^{2}\left(R_{f}\right)+W_{2}^{2} \sigma^{2}\left(\widetilde{R_{m}}\right)+2 w_{1} w_{2} \operatorname{cov}\left(R_{f}, \widetilde{R_{m}}\right)}
$$

Sendo:

- $\operatorname{Cov}\left(R_{i}, R_{m}\right)$ = covariância entre os retornos do ativo e os retornos da carteira de mercado;

Dado que o ativo livre de risco - $\mathrm{R}_{\mathrm{f}}$ - apresenta desvio padrão nulo e covariância com a carteira de mercado - $\operatorname{cov}\left(\mathrm{R}_{\mathrm{f}}, \widetilde{\mathrm{R}_{\mathrm{m}}}\right)$ - também igual a zero, temos que:

$\sigma\left(\widetilde{R_{p}}\right)=w_{2} \sigma\left(\widetilde{R_{m}}\right)$

A análise da equação (2.8) indica que há uma relação linear entre o risco das carteiras posicionadas sobre a LMC e o risco da carteira de mercado.

A inclinação da LMC corresponde ao coeficiente angular da reta:

Coeficiente Angular da $\mathrm{LMC}=\frac{\mathrm{E}\left(\widetilde{\mathrm{R}_{\mathrm{p}}}\right)-\mathrm{R}_{\mathrm{f}}}{\sigma_{m}}$ 
Considerando a carteira de mercado $m$, o gráfico 6 apresenta a curva de possibilidades de composições de uma carteira formada por um ativo $i$ e a carteira de mercado.

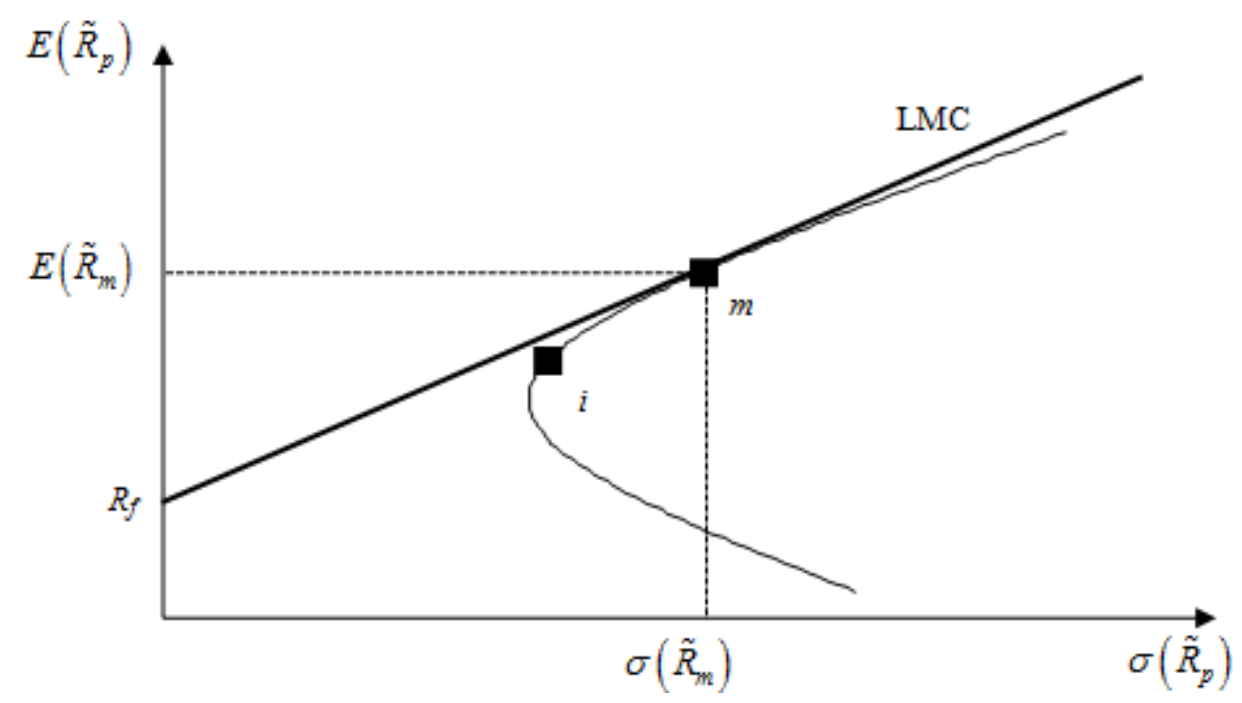

Gráfico 6 - Relação entre um Ativo Individual e a LMC

A carteira de mercado definida por Sharpe (1970) é composta por todos os ativos com risco negociáveis na economia. Ou seja, ações, títulos de dívida, ativos imobilizados, ouro compõem a carteira de mercado, representados na seguinte proporção:

$\mathrm{X}_{\mathrm{i}}=\frac{\text { Valor de Mercado do ativo i }}{\text { Valor de Mercado de todos Ativos da Economia (Carteira de Mercado) }}$

Considerando:

$\mathrm{X}_{\mathrm{i}}$ : proporção de cada ativo presente na carteira de mercado em condição de equilíbrio;

No ponto i, os ativos estão integralmente aplicados no ativo $i$, e no ponto $m$, os ativos estão integralmente alocados na carteira de mercado. Vale ressaltar que o ativo $i$ também compõe a carteira de mercado, o que implica que no ponto $m$ há também alocação de recursos no ativo a. 
Uma carteira $p$ composta pelo ativo $i$ e pela carteira de mercado, na proporção de $\mathrm{x}$ e (1-x) respectivamente, tem o seguinte retorno esperado:

$$
E\left(\tilde{R}_{p}\right)=x E\left(\tilde{R}_{i}\right)+(1-x) E\left(\tilde{R}_{m}\right)
$$

E o risco (desvio-padrão) da carteira p é dado por:

$$
\sigma_{p}=\left[x^{2} \sigma_{i}^{2}+(1-x)^{2} \sigma_{m}^{2}+2 x(1-x) \sigma_{i, m}\right]^{1 / 2}
$$

Alterações na proporção de ativos i na composição das carteiras compostas por $i$ e por $m$ geram alterações no retorno e risco da carteira resultante, representadas pela curva ic formada no espaço média-variância (Gráfico 7).

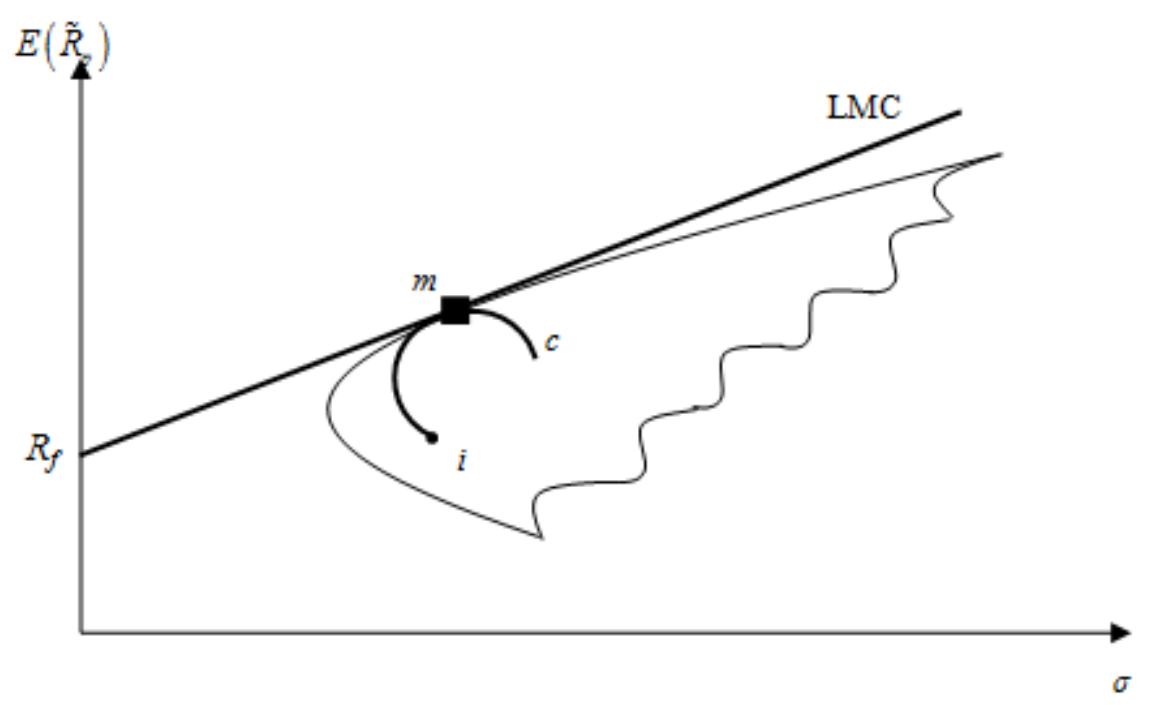

Gráfico 7 - Curva da carteira p

Fonte: LUENBERGER; 1998, p. 178.

A variação do retorno e risco da carteira resultante da nova combinação proposta pode ser observada derivando-se (2.10) e (2.11) em função de x:

$$
\frac{d E\left(\tilde{R}_{p}\right)}{d x}=E\left(\tilde{R}_{i}\right)-E\left(\tilde{R}_{m}\right)
$$




$$
\frac{d \sigma_{p}}{d x}=\frac{x \sigma_{i}^{2}+(1-2 x) \sigma_{i, m}+(x-1) \sigma_{m}^{2}}{\sigma_{p}}
$$

Carteiras compostas com $x \neq 0$ rompem a premissa de equilíbrio de mercado, dado que a inserção de maior quantidade de ativo i na composição da nova carteira altera sua respectiva proporção na carteira de mercado.

Assim, impondo-se a condição de equilíbrio de mercado, ou seja, $\mathrm{x}=0$, para (2.13) tem-se:

$$
\begin{aligned}
& \frac{\mathrm{dE}\left(\widetilde{\mathrm{R}_{\mathrm{p}}}\right)}{\mathrm{dx}} \mid \mathrm{x}=0=\mathrm{E}\left(\widetilde{\mathrm{R}_{\mathrm{l}}}\right)-\mathrm{E}\left(\widetilde{\widetilde{\mathrm{R}_{\mathrm{m}}}}\right) \\
& \frac{\mathrm{dE}\left(\widetilde{\mathrm{R}_{\mathrm{p}}}\right)}{\mathrm{dx}} \mid \mathrm{x}=0=\frac{\sigma_{\mathrm{i}, \mathrm{m}}-\sigma_{\mathrm{m}}^{2}}{\sigma_{\mathrm{m}}}
\end{aligned}
$$

Dividindo-se (2.14) por (2.15), temos que:

$$
\frac{\frac{d E\left(\overline{R_{p}}\right)}{d x}}{\frac{d E\left(\overline{R_{p}}\right)}{d x}} \mid x=0=\frac{E\left(\widetilde{R_{1}}\right)-E\left(\widetilde{R_{m}}\right)}{\frac{\sigma_{i, m^{-}}-\sigma_{m}^{2}}{\sigma_{m}}}
$$

A equação (2.16) corresponde ao coeficiente angular da reta tangente à carteira resultante da curva da carteira $\mathrm{p}$.

Dado que assumimos que $\mathrm{x}=0$, a inclinação da linha da reta característica do mercado, ou seja, equação (2.16), deve ser igual à inclinação da reta da carteira de mercado. 


$$
\frac{\left[E\left(\tilde{R}_{i}\right)-E\left(\tilde{R}_{m}\right)\right] \sigma_{m}}{\sigma_{i, m}-\sigma_{m}^{2}}=\frac{E\left(\tilde{R}_{m}\right)-R_{f}}{\sigma_{m}}
$$

Reorganizando (2.17) em função de $\mathrm{E}\left(\widetilde{\mathrm{R}_{1}}\right)$,

$$
\begin{aligned}
& E\left(\tilde{R}_{i}\right)=R_{f}+\left(\frac{E\left(\tilde{R}_{m}\right)-R_{f}}{\sigma_{m}^{2}}\right) \sigma_{i, m}, \text { ou } \\
& E\left(\tilde{R}_{i}\right)=R_{f}+\left(E\left(\tilde{R}_{m}\right)-R_{f}\right) \frac{\sigma_{i, m}}{\sigma_{m}^{2}}
\end{aligned}
$$

Substituindo $\frac{\sigma_{i, m}}{\sigma_{m}^{2}}$ por $\beta_{\mathrm{i}, \mathrm{m}}$ em (2.18):

$$
E\left(\widetilde{R_{1}}\right)=R_{f}+\beta_{i, m} *\left[E\left(\widetilde{R_{m}}\right)-R_{f}\right]
$$

Em que:

$\mathrm{E}\left(\widetilde{\mathrm{R}_{1}}\right)=$ retorno esperado do ativo $i$

$\mathrm{R}_{\mathrm{f}}=$ retorno do ativo livre de risco;

$\beta_{\mathrm{i}, \mathrm{m}}=$ Fator de risco sistêmico, ou seja, sensibilidade dos retornos do ativo $i \mathrm{em}$ relação aos retornos da carteira de mercado;

$\mathrm{E}\left(\widetilde{\mathrm{R}_{\mathrm{m}}}\right)=$ Retorno esperado da carteira de mercado;

Assim, em condições de equilíbrio, o retorno esperado de um ativo é resultado de uma função da taxa livre de risco, do risco sistêmico do ativo (medido pelo 
respectivo Beta) e do prêmio pelo risco da carteira de mercado em relação ao ativo livre de risco.

A equação apresentada demonstra que o retorno esperado de um ativo deve variar de acordo com o nível de risco adicional gerado por sua inserção em uma carteira diversificada que apresente apenas o risco de mercado.

O CAPM demonstra, portanto, a relação entre o retorno esperado de um ativo qualquer e o risco adicional imposto por tal ativo à uma carteira diversificada de investimentos mantida pelo investidor. $\mathrm{O}$ modelo não define a relação entre retorno esperado e variância (risco total) de um ativo isoladamente. (MALAGA, 2007, p.100).

É importante notar que a medida de risco do novo ativo no CAPM é representada pelo Beta, cujo cálculo será detalhado mais adiante.

\subsection{Tipos de risco}

\subsubsection{Risco Sistêmico e risco não sistêmico}

A questão da avaliação do risco sistêmico foi desenvolvida por William Sharpe em 1964, com seu celebrado artigo Capital Asset Prices: A Theory of Market Equilibrium under Conditions of Risk. Sharpe constatou que o risco total que todo ativo incorre é formado por dois distintos componentes: Um risco sistêmico, e uma parcela não correlacionado com o risco de mercado, denominada risco não sistêmico.

Assim, o risco - ou variância - de um ativo segundo o modelo do CAPM é calculado da seguinte forma:

$$
\sigma_{i}^{2}=\beta_{i, m}^{2} * \sigma_{m}^{2}+\sigma_{\widetilde{S I}}^{2}
$$

Em que:

$\sigma_{i}^{2}=$ Risco total, ou variância do ativo $i$; 
$\beta_{i, m}^{2} * \sigma_{m}^{2}=$ Parte da variância total advinda do risco sistêmico, ou seja, parcela da variância total atribuída à variância da carteira de mercado;

$\sigma_{\widehat{S I}}^{2}=$ Risco não sistêmico;

O risco sistêmico corresponde ao componente não diversificável de risco, inerente a conjuntura econômica, política e social, e que impacta de forma abrangente todos os agentes atuantes em uma dada economia. Assim, um processo conturbado de eleição em um país pode gerar um risco sistêmico que impactará diretamente todos os ativos.

Securato (2007) ressalta que diferentes ativos possuem diferentes reações a um determinado risco sistêmico. Assim, uma crise política em determinado país poderá impactar de formar mais intensa setores dependentes do câmbio - como o exportador - do que outros setores em uma mesma economia.

Assim, conforme a conjuntura econômica, política e social, tem-se estabelecida uma posição relativa da taxa de retorno dos vários ativos. [...] variações da conjuntura [...] rearranjam a maioria dos ativos, - é este risco que o sistema impõe ao ativo [...]. É importante frisar que o risco conjuntural é tanto maior quanto maiores são as possibilidades de variação da conjuntura [...]. (SECURATO, 2007, p. 48- 49).

Já o risco não sistêmico refere-se ao componente de risco específico do ativo e do contexto específico em que ele se insere. Assim, a descoberta de uma nova bacia petrolífera, como a recém descoberta dos campos de pré-sal no Brasil, atinge ativos relacionados somente a este contexto específico, não oferecendo risco as demais ativos na economia.

Com a adoção das premissas anteriormente relacionadas, o CAPM parte da premissa que o investidor é capaz de diversificar todo o risco não sistemático, existindo assim a possibilidade de seu impacto ser gerido pelos administradores da empresa.

A questão de diversificação do risco não sistêmico é crucial no arcabouço teórico que envolve do CAPM, fundamentando a hipótese que nem todos os riscos devem 
afetar o preço de um ativo, sendo somente passível de remuneração o risco sistemático.

Em particular, um risco que pode ser efetivamente diversificado quando mantido com outros investimentos em um portfólio não é, de forma bastante real, efetivamente um risco. O CAPM nos proporciona insights sobre que tipo de risco é relacionado com retorno. (PEROLD, 2004, p.3) ${ }^{15}$.

\subsubsection{Outras classificações de risco}

O risco mais comumente relacionado às instituições financeiras é o risco de crédito. Porém há muitos outros riscos que afetam a atividade bancária, como risco de liquidez, risco de mercado, risco legal e risco operacional. Saunders (2000) detalha nove tipos de riscos que afetam instituições financeiras, conforme apresentando sucintamente a seguir:

Risco de variação de taxa de juros: $O$ descasamento do vencimento de ativos e passivos expõe instituições financeiras à variações de taxa de juros. Quanto maior o descasamento do prazo de vencimento de ativos e passivos, maior a exposição da instituição financeira a esse tipo de risco.

Risco de mercado: Risco oriundo das oscilações no preço de ativos em direções opostas às esperadas, gerando incertezas em relação ao lucro projetado. $\mathrm{O}$ autor cita, como exemplo de problemas gerados pelo risco de mercado, a quebra do banco de investimento inglês Barings, em 1995. A instituição se tornou insolvente ao apostar na alta de contratos futuros do índice japonês Nikkei, e ser surpreendida com a forte queda inesperada do índice, gerando perdas de mais de USD 1,2 bilhões.

Risco de crédito: Relaciona-se à potenciais perdas em função do não recebimento de direitos adquiridos sobre as obrigações a pagar previamente assumidas por clientes e contratantes. "Há o risco de crédito porque os fluxos de caixa prometidos

\footnotetext{
15 "In particular, a risk that can be diversified away when held along with other investments in a portfolio is, in a very real way, not a risk at all. The CAPM gives us insights about what kind of risk is related to return."
} 
pelos títulos primários possuídos por IFs podem não ser pagos integralmente." (SAUNDERS, 2000. p. 102).

Risco de operações fora do balanço: Refere-se a ativos e passivos que não aparecem no balanço patrimonial corrente, como cartas de fianças, contratos futuros, swaps, e outros tipos de derivativos. Saunders (2000) ressalta que o impacto sobre o balanço patrimonial de operações como as citadas acontece no futuro, dado a possibilidade de geração de um ativo ou passivo condicional.

Risco tecnológico e operacional: Advém da possibilidade de perdas devido a falhas em sistemas, falhas humanas ou falhas em processos. Saunders (2000) ressalta que o risco tecnológico acontece quando os investimentos em tecnologia não geram as economias de escopo e escala esperadas, não reduzindo os custos das instituições. O autor ressalta que o risco operacional pode estar relacionado, em parte, ao risco tecnológico, ocasionando falhas em sistemas de apoio, por exemplo.

Risco de câmbio: Caracteriza-se pela exposição dos ativos e passivos das instituições financeiras à volatilidade das taxas de câmbio, gerando a possibilidade de perdas. Saunders (2000) ilustra este tipo de risco com o caso de uma instituição financeira americana que realiza um empréstimo em libras para uma empresa britânica. Caso a libra se desvalorize em relação ao dólar há uma perda de valor, em termos de dólar, para a instituição americana. Se a desvalorização for demasiadamente forte, há inclusive a possibilidade de originação de um fluxo negativo para a operação.

Risco soberano: Surge quando há possibilidade de geração de prejuízos devido à influências sociopolítica e econômicas de um país. Saunders (2000) afirma que as considerações sobre risco soberano devem dominar as ponderações a respeito do risco de crédito privado. Assim, se um tomador de empréstimo possui adequado perfil de risco, mas está lotado em um país com alto risco soberano, o empréstimo não deverá ser feito.

Risco de liquidez: O descasamento entre ativos e passivos de uma instituição financeira cria a possibilidade da instituição não possuir recursos para cumprir suas obrigações previamente assumidas, gerando assim o risco de liquidez. 
Risco de insolvência: Decorrente da conjunção de diversos tipos de riscos, ocorre quando os recursos próprios do intermediário financeiro são insuficientes para cobrir suas perdas. Saunders (2000) ressalta que, de forma geral, o risco de insolvência é minimizado conforme se reduz o nível de endividamento dos intermediários financeiros.

Buscando ampliar o conceito de gerenciamento de risco, Jorion (2000) apresenta uma classificação de risco distinta, agrupando riscos em duas grandes categorias: os riscos vinculados ao negócio (business risk) - subdivididos em risco de produto, risco macroeconômico e risco tecnológico - e os riscos não vinculados ao negócio (non business risk) - subdivididos em risco de evento e riscos financeiros conforme detalhado no gráfico 8.

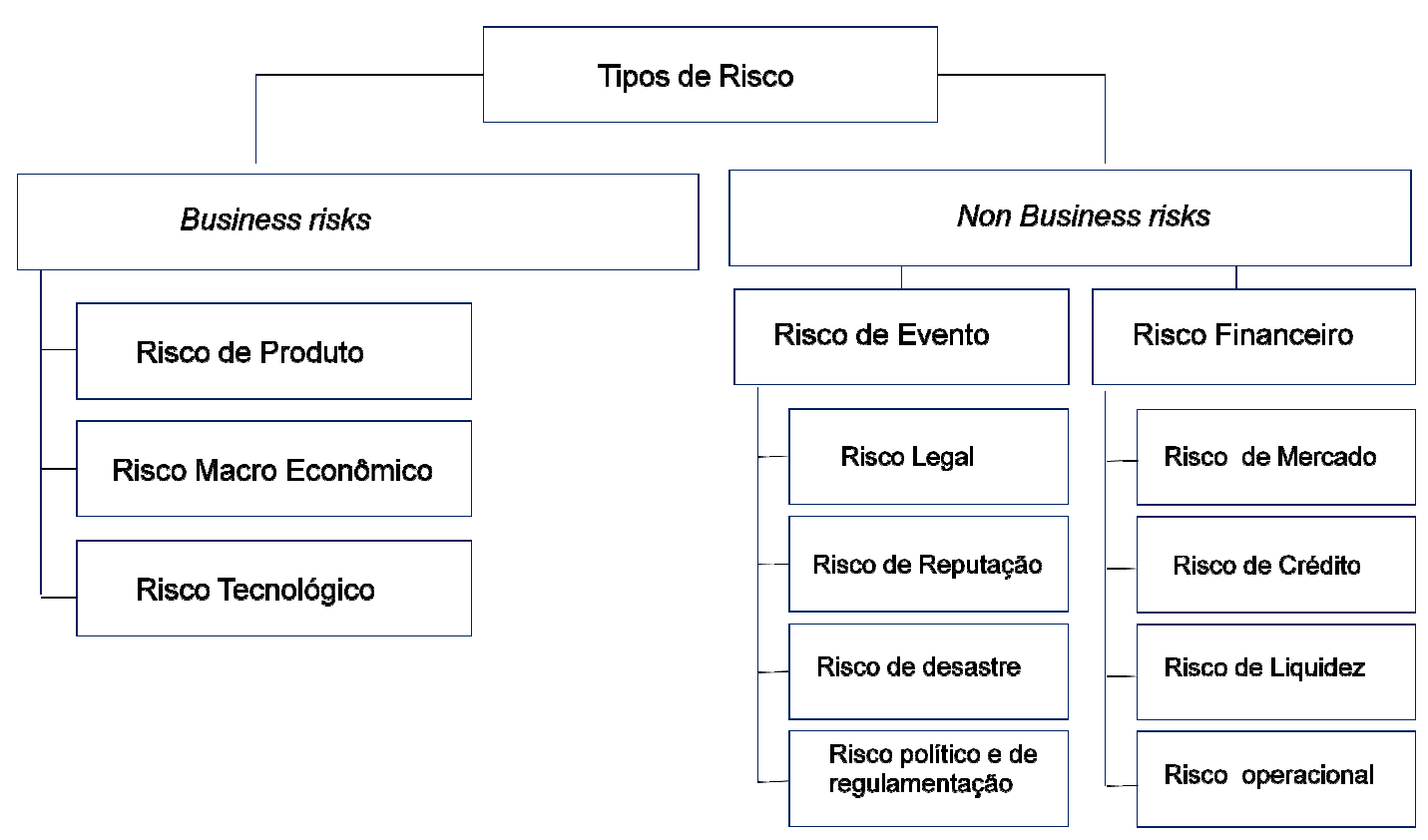

Gráfico 8 - Classificações de risco segundo Jorion (2000)

Fonte: Elaborado pela autor.

Para Jorion, business risks são aqueles que a organização assume com o intuito de criar uma vantagem competitiva. Em outras palavras, ela possui controle sobre estes riscos. Assim, inovações tecnológicas em um produto ou alterações na forma de sua promoção seriam exemplos de riscos assumidos pelas organizações de forma ativa, visando um novo patamar de lucratividade. Já os non business risks são aqueles não vinculados ao negócio e sobre os quais a organização não tem controle. 
Jorion (2000) ressalta que, embora riscos de eventos - como riscos de regulamentação - estejam fora da esfera de controle das organizações, alguns são transferíveis, existindo assim a possibilidade de proteção por meio de seguro.

Outra classificação bastante utilizada no mercado apresenta os riscos em 4 categorias: risco de mercado, risco operacional, risco de crédito e risco legal. Esta classificação foi desenvolvida pelo G30 - Global Derivatives Study Group, grupo sediado em Washington e formado por estudiosos do mercado financeiro e mercado de capitais no mundo. Apesar de ser bastante utilizada como referência para riscos financeiros, esta classificação foi desenvolvida originalmente para classificação de riscos de derivativos - tanto para usuários finais quanto para intermediários - e foi apresentada no trabalho Derivatives: Practises and Principles, divulgado pelo grupo em julho de 1993.

\subsection{0 fator beta de risco}

O beta é uma medida de risco sistêmico, ou seja, refere-se ao componente de risco não diversificável que incidirá em um determinado ativo. Esta medida compara o risco de um ativo com o risco do mercado.

Matematicamente, o Beta pode ser calculado da seguinte forma:

$\beta_{i}=\frac{\sigma_{i m}}{\sigma_{m}^{2}}=\frac{\operatorname{Cov}\left(R_{i}, R_{m}\right)}{\operatorname{VAR}\left(R_{m}\right)}$

Sendo:

- $\operatorname{Cov}\left(R_{i}, R_{m}\right)=$ covariância entre os retornos do ativo e os retornos da carteira de mercado;

- $\operatorname{VAR}\left(R_{m}\right)$ = variância dos retornos da carteira de mercado;

Dessa forma, ativos que apresentem retorno com alta covariância em relação a uma carteira de mercado serão classificados como mais arriscados, dado que contribuirão para aumentar o risco da carteira. Como consequiência, uma taxa de retorno maior será esperada como forma de compensar o incremento no risco. 
O cálculo do Beta é extremamente sensível ao processo de estimação utilizado. Damodaran (1999, p.7) ressalta três aspectos que podem influenciar o cálculo do Beta:

- O horizonte de tempo utilizado para o cálculo;

- A freqüência do retorno dos ativos e do mercado utilizado como referência;

- A determinação da proxy da carteira de mercado utilizada no cálculo;

Como conseqüência de diferentes escolhas para o horizonte de tempo, freqüência dos retornos e determinação da proxy para carteira de mercado, diferentes estimativas de beta podem surgir para uma mesma firma.

No que tange a definição do horizonte adequado para a análise e a freqüência de dados disponíveis, Bartholdy e Peare (2001) ressaltam que, ao estimar um parâmetro, a opção mais adequada é buscar o maior número de observações disponíveis, sugerindo assim que se use o horizonte de tempo mais abrangente possível. Porém, para os autores, esta regra é adequada para casos em que não haja anomalias no mercado. Períodos marcados por grandes alterações na esfera econômica, como a recente crise financeira de 2008, afetarão o cálculo do Beta.

Annema e Goedhart (2003) apontam, como forma de dirimir o problema de períodos anormais, que períodos de crise e bolha especulativa devem ser retirados do horizonte de análise. A fragilidade desta proposta é clara: a subjetividade em definir o que é um momento de anomalia pode gerar mais uma vez resultados inapropriados.

Já os aspectos relacionados à definição da carteira de mercado não traz menores complicações. Na teoria do CAPM, entende-se como carteira de mercado aquela formada por todos os ativos passíveis de negociação em uma economia. Rolls (2007) argumenta ser impossível determinar com precisão a carteira efetivamente representativa do mercado. Dado a dificuldade em se determinar com precisão esta carteira referencial, na prática proxies - representações aproximadas de uma carteira de mercado - são utilizadas. Tal prática, segundo o autor, traz um elevado grau de subjetividade para a análise. 
Apesar da limitação apontada em relação à utilização de proxies de uma carteira de mercado, não há consenso em relação ao tema. Autores como Brealey (2008), Ross (2007), Damodaran (1999), Siegel (1999) e Woolridge (1996) apresentam estudos que mostram as possíveis variabilidades de retornos que podem surgir de acordo com a definição da proxy para a carteira de mercado. Neste sentido, autores como Damodaran (1999) e Bartholdy e Peare (2001) ressaltam a importância de se analisar a consistência dos dados, transformando a criação da proxy de uma carteira em um minucioso processo, sujeito a alterações no decorrer dos trabalhos.

\subsection{Hipótese de mercados eficientes (HME)}

A base teórica da hipótese de mercados eficientes (HME) remonta à teoria do random walk de Bachelier (1990), sendo mais tarde consolidada nos trabalhos de Paul Samuelson (1965) e Benoit Mandelbrot (1966), que supuseram que o investidor age racionalmente ao tomar decisões que resultem em alterações nos preços das ações nos mercados. A conseqüência seria uma natural equivalência entre preço e valor. O componente randômico no processo de formação de preços dos ativos tornaria impossível qualquer tipo de previsão sobre o preço futuro dos ativos.

A questão de movimentos imprevisíveis já demonstra que o pressuposto da racionalidade não era absolutamente predominante até então, havendo espaço para a participação de comportamento irracional na formação dos preços. Neste sentido, haveria uma tendência dos preços se distanciarem do valor real.

A teoria porém continuou a se desenvolver, e a hipótese da arbitragem praticada por participantes racionais ganhou força, sendo assim um caminho natural para garantir a igualdade entre preço e valor, reforçando as conclusões básicas do modelo (CUNNINGHAM, 2002).

Esse conceito de preço justo, refletindo todo tipo de informação disponível de forma a igualar preço à fundamentos, gerou inúmeros trabalhos em finanças, sendo os mais notórios a Teoria de Seleção de Carteiras proposta por Markowitz (1952) e a Teoria de Precificação de Ativos (CAPM) proposta por Sharpe (1964), agraciados 
com o prêmio Nobel por suas contribuições. Mas apesar dos desenvolvidos prévios apontados, a HME é formalizada a partir dos trabalhos de Fama, em 1970.

Portanto repousa em Eugene Fama os pressupostos da HME, considerando que os preços dos ativos refletem de forma imediata e não enviesada todas as informações disponíveis no mercado. Esta teoria é resumida na célebre frase de Fama, que afirma que os preços "refletem plenamente" (FAMA, 1970, p.383) toda a informação disponível.

De acordo com o arcabouço teórico que serve como base da HEM, o preço do ativo reflete todas as informações disponíveis sobre a instituição emissora, impossibilitando que investidores gozem de qualquer tipo de ganho anormal. Assim, não seria possível para o investidor auferir qualquer tipo de retorno superior ao retorno ajustado pelo risco de determinado ativo.

Na HEM, there is no free lunch. Nenhuma estratégia de investimento pode ganhar retornos anormais ajustado pelo risco, ou tampouco retornos maiores do que o garantido para o respectivo nível de risco. (BARBERIS, THALER 2003).

Como a HME desenha um cenário em que todo tipo de informações disponível no mercado já fora incorporada instantaneamente ao preço da ação pelos operadores de mercado que obtiveram acesso a informação antes dos demais, informações antigas teriam pouco utilidade para o investidor. Seu potencial impacto no preço da ação já estaria computado pelo mercado, não sendo qualificado como vantajoso o acesso a esse tipo de informação.

$\mathrm{Na}$ prática, no mercado acionário os preços incorporariam todo o tipo de informação disponível, sendo assim a melhor estimativa do valor fundamental dos ativos.

Para que a HEM aconteça, Aldrighi e Milanez (2005), apontam as seguintes condições:

- Concorrência deve ser perfeita;

- As preferências dos investidores são estáveis;

16 "Fully reflects" 
- As expectativas dos investidores são homogêneas;

- Novas informações surgem aleatoriamente, e o ajuste das informações nos portfólios dos investidores deve ser instantâneo;

- Ausência de fricções, ou seja, os ativos são homogêneos, divisíveis, e não há custo de transação;

- Os investidores processam de maneira ótima a informação;

Diante de tais premissas vale ressaltar dois pontos. O primeiro diz respeito ao fato que a HME parte do pressuposto que existe racionalidade por parte dos investidores. Mas esta racionalidade não precisa necessariamente ser esperada para todos os participantes do mercado. Eventuais discrepâncias geradas por investidores não racionais (noise traders) seriam compensadas pela ação dos chamados arbitradores racionais (smart traders), que rapidamente operariam de maneira a auferir lucro em cima das discrepâncias de preços não correlacionados com os fundamentos, fazendo com que o preço da ação novamente igualasse seus pressupostos econômicos.

O segundo ponto faz referência ao impacto imediato das informações no preço dos ativos. Cunningham (2002) chama atenção para a questão da vantagem que um investidor pode ou não obter em operações no mercado acionário. Para o autor, é possível que investidores obtenham lucro no mercado acionário por meio de informações privilegiadas, mas o ponto da HEM é que não é possível ganhar mais dinheiro utilizando informações desatualizadas de forma a compensar o risco pelo investimento. Na HEM, risco é ajustado pelo capital asset pricing model (CAPM), que especifica o risco associada a cada ação. Informações desatualizadas não teriam utilidade para a busca de lucratividade.

Assim, a ausência de impacto de informações desatualizadas no preço das ações implica nos mesmos resultados que o modelo de passeio aleatório (randow walk model), ou seja, padrões passados de preço não são relevantes para a formação do preço futuro das ações, dado que as mudanças de preços são não correlacionadas e independentes em relação aos dados passados. E é justamente o conceito do passeio aleatório que está por trás da base do artigo de Fama (1970). 
Nos primeiros trabalhos a respeito do modelo de eficiência de mercado, a afirmação que o valor corrente de um ativo "reflete plenamente" informação disponível implicava que sucessivas mudanças de preço [...] são independentes. E mais, normalmente assumia-se que mudanças (ou retornos) são distribuídas de forma idêntica. As duas hipóteses juntas constituem o modelo do passeio aleatório. (FAMA, 2004, p. 386) ${ }^{17}$.

A ênfase dada pelo autor no termo "reflete plenamente" não é a toa. Fama (1970) propôs três formas de eficiência de mercado, averiguando o nível de eficiência do mercado em relação ao nível de informação especificada:

- Eficiência Fraca: ocorre quando os preços refletem completamente dados passados de preço e retorno dos ativos;

- Eficiência semi-forte: não apenas informações sobre os dados passados de preço e retorno dos ativos refletem no preço dos ativos, mas todo tipo de informação publicamente disponível;

- Eficiência forte: Os preços refletem, além das informações históricas e públicas, informações privadas. Ou seja, todo tipo de informação disponível apresenta impacto no preço das ações, e os preços refletem os fundamentos de mercado.

Em virtude de a forma forte ser de difícil comprovação, e possuir pouco crédito mesmo entre os economistas defensores da HME, as discussões se concentram entre as formas fracas e semi-forte.

\subsection{Distorções à racionalidade - finanças comportamental}

A forma como o comportamento influencia a tomada de decisão do investidor profissional, gerando erros de julgamentos que contrariam as bases da HME, forma o contexto de estudo das finanças comportamentais.

\footnotetext{
17 "In the early treatments of the efficient markets model, the statement that the current price of a security "fully reflects" available information was assume to imply that successive price changes [...] are independent. In addition, it was usually assumed that successive changes (or returns) are identically distributed. Together the two hypotheses constitute the randow walk model."
} 
O termo finanças comportamentais é definido por Shefrin (2002) como a aplicação de conceitos de psicologia ao comportamento daqueles que, de alguma forma, atuam no mercado financeiro. A literatura de finanças comportamentais estuda os mercados financeiros por meio de modelos menos rígidos que os propostos pelas teorias de maximização de utilidade e de arbitragem (RITTER, 2002).

As teorias tradicionais de finanças utilizam modelos que pressupõem a racionalidade dos agentes de mercado para entender seu comportamento. Segundo Barberis e Thaler (2003), o conceito de racionalidade aplicado a finanças significa que os agentes atualizam rapidamente seus comportamentos quando encontram novas informações, supondo também que a informação disponível é perfeita.

Assim, rigorosamente, o termo finanças comportamentais é redundante, pois a proposição de modificações nos modelos e teorias, de forma a incorporar aspectos irracionais, é a característica natural do estudo de finanças comportamental (THALER, 1999; FRANKFURTER, MCGOUN, 2005).

Diversos trabalhos foram feitos, a partir da década de 1970, com o objetivo de entender e agregar aos modelos financeiros tradicionais idéias e elementos dos comportamentos considerados irracionais pelas teorias tradicionais. O desenvolvimento das idéias e teorias comumente conhecidas como finanças comportamentais obteve grande desenvolvimento quando alguns psicólogos desenvolveram estudos sobre o comportamento econômico dos seres humanos. Entre eles destacam-se Kahneman e Tversky (1972), dando continuidade aos estudos de Simon (1957) sobre racionalidade limitada.

Shefrin (2002) argumenta que poucos fenômenos psicológicos contemplam todo o horizonte das finanças. Assim, o autor organizou estes fenômenos em três grandes temas: viés heurístico, efeitos de estruturação e mercados ineficientes. Estes temas são detalhados a seguir.

\subsubsection{Viés heurístico}

Simon (1957), em seu trabalho vencedor do prêmio Nobel, sugeriu que o julgamento individual fica restringido pela sua racionalidade. Tversky e Kahneman (1974), quinze anos após a publicação dos trabalhos de Simon, continuaram o 
desenvolvimento da mesma linha de pesquisa, fornecendo informações críticas sobre os vieses sistemáticos específicos que influenciam o julgamento. Segundo estes estudos, indivíduos desenvolvem regras práticas - "regras de bolso" - ou heurísticas, para reduzir as exigências de processamento de informações da tomada decisão.

Diante da racionalidade limitada, os indivíduos utilizam princípios heurísticos, dado que o referido recurso reduz "[...] a operações mais simples de julgamentos as tarefas complexas de avaliar as probabilidades e de prever valores. No geral, essas heurísticas são bastante úteis, mas às vezes elas levam a erros graves e sistemáticos." (TVERSKY, KAHNEMAN, 1974 apud ALDRIGHI, MILANEZ, 2005, p.64).

\section{a. Representatividade}

Insensibilidade aos números básicos - Para exemplificar esse viés, Bazeman (2004) discorre sobre o seguinte exemplo: um jovem estudante de MBA, apaixonado por artes e música, e prestes a terminar seu curso em uma renomada escola de negócios, possui duas opções de emprego. A primeira corresponde a um emprego em direção de arte, e a segunda opção refere-se a um emprego em uma empresa start-up de internet. Qual emprego o estudante provavelmente escolherá? Como o estudante é bastante representativo da imagem de um amante de artes, neste exemplo a grande maioria das pessoas aponta a primeira opção, desprezando informações relevantes fornecidas por índices básicos (um número muito maior de estudantes de MBA em escolas renomadas optam por ingressar em empresas startup de internet em detrimento ao cargo de direção de artes).

Tversky e Kahneman (1974) ressaltam que pessoas tendem a avaliar a probabilidade de ocorrência de um determinado evento baseadas em estereótipos, muitas vezes não utilizando índices básicos - como a taxa de freqüência de um determinado evento - no embasamento de sua escolha.

Porém os autores destacam que, em situações em que não haja nenhuma outra informação disponível, as pessoas usam corretamente os dados de índices básicos.

Insensibilidade ao tamanho da amostra - A análise racional de um problema demonstra que o tamanho da amostra é um fator fundamental na estatística. 
Tversky e Kahneman (1974) porém argumentam que o tamanho da amostra raramente colabora com a intuição das pessoas. Para exemplificar o caso, os autores elaboraram o seguinte problema/experimento: em uma cidade há dois hospitais. No maior, nascem aproximadamente 45 bebês por dia, e no menor 15 bebês. Em média $50 \%$ dos bebês são do sexo masculino. A porcentagem exata varia dia a dia. Em um ano, cada hospital registra o número de dias em que o ocorreu o nascimento de $60 \%$ dos bebês do sexo masculino. Em qual dos dois hospitais teria apresentado a maior ocorrência de dias em que haja mais bebês masculinos do que femininos?

Opção A - Hospital maior;

Opção B - Hospital menor;

Opção C - Probabilidades iguais de ocorrência.

A grande maioria das respostas coletadas pelos autores apontam para a alternativa $\mathrm{C}$, ignorando a teoria da amostragem, que demonstra que é muito mais fácil observar a ocorrência de $60 \%$ de nascimentos de crianças do sexo masculino em uma amostra de 15 representantes do que em uma amostra com 45 indivíduos. Extrapolando o exemplo, seria mais fácil observar a ocorrência de 50\% professores mestres e doutores em uma amostra com 20 alunos ou em uma amostra com 20.000 alunos?

Interpretação errada da chance - a pesquisa de Tversky e Kahneman (1972) demonstra que pessoas, em um experimento de moedas envolvendo as possibilidades cara $(\mathrm{H})$ e coroa $(\mathrm{T})$, esperam uma maior probabilidade para a seqüência H-T-H-T-T-H do que para a seqüência H-H-H-H-T-H. Com este posicionamento, as pessoas simplesmente ignoram o conceito de independência de eventos aleatórios, que implica que há igual probabilidade para a ocorrência das alternativas mencionadas. Trazendo o exemplo mais próximo do mercado de capitais, não é difícil ver no dia a dia o exemplo de um investidor que, por já ter perdido dinheiro ao investir em cincos diferentes tipos de ações, julga que sua chance de perda com uma sexta ação seja inferior às anteriores. Uma alternativa absolutamente inválida, dado a independência de eventos aleatórios.

Insensibilidade a previsão - Tversky e Kahneman (1974) exemplificam esse viés detalhando a metodologia de previsão da lucratividade de uma empresa baseada em 
apenas uma informação. Caso se disponha apenas da descrição de uma empresa, e caso essa informação seja extremamente positiva, a previsão de um lucro muito alto parece ser mais representativo para a empresa. Seguindo a mesma lógica, caso haja apenas uma descrição medíocre da empresa, uma previsão de performance medíocre será mais representativa para a empresa.

Portanto, as pessoas tendem a realizar uma previsão selecionando o outcome mais representativo para o input disponível.

Há dois grandes problemas que podem levar a erros de previsão nesta situação: a possível falta de confiabilidade da informação que foi usada para realizar a previsão; e a correta avaliação do grau de relevância da informação para realizar a previsão.

Ilusão da validade - esse viés relaciona-se diretamente aos pontos problemáticos elencados no viés relativo à insensibilidade a previsão: a injustificada confiança que é produzida por um bom encaixe entre a informação utilizada como input e o outcome observado.

[...] pessoas expressam grande confiança para prever que uma pessoa é bibliotecária quando a descrição da personalidade desta pessoa é coerente com o estereótipo de um bibliotecário, mesmo que a descrição seja limitada, pouco confiável, ou desatualizada. (TVERSKY, KAHNEMAN, 1974, p.1126) ${ }^{18}$.

Interpretação errada da reversão à média - Em qualquer esfera da vida cotidiana, muitos eventos podem tender a média. Essa afirmação é estatisticamente válida, mas muitas vezes contra intuitiva para pessoas.

Tversky e Kahneman (1974) salientam que a regressão à média é comum em distintos aspectos, como a altura de pais e filhos, a inteligência de maridos e esposas, ou a performance de indivíduos em consecutivas avaliações.

\footnotetext{
18 “[...] people express great confidence in the prediction that a person is a librarian when given a description of his personality which matches the stereotype of librarian, even if the description is scanty, unreliable, or outdated."
} 
Os autores sugerem que umas das causas para tal feito pode ser a já citada crença de compatibilidade entre os inputs e os outcomes de uma análise. Assim, informações extremas levariam a uma conclusão também extrema.

O risco é iminente quando administradores, gestores de ações, investidores e demais atores do sistema financeiro não reconhecem o princípio da regressão à média, e pode gerar distorções em previsões que não acompanham a geração real de valor.

Considere um empregado cujo desempenho seja extremamente bom durante um período de avaliação. Ele (e seu patrão) pode esperar, indevidamente, um desempenho semelhante no próximo período. O que acontece quando o desempenho do empregado regride à média? [...] Administradores que geralmente falham em reconhecer a tendência de regressão à média [...] desenvolverão falsas premissas sobre resultados futuros e, como resultado, farão planos inadequados. (BAZEMAN , 2004, p.32, grifo meu).

b. Disponibilidade

Recuperabilidade de exemplos - "É uma experiência comum que a probabilidade subjetiva de ocorrências de acidentes de trânsito aumente temporariamente quando uma pessoa enxergue um carro capotado no acostamento de uma estrada." $\left(\right.$ TVERSKY E KAHNEMAN, 1974, p.1127) ${ }^{19}$.

Seguindo este raciocínio, temos o exemplo da superestimação de riscos de acidentes aéreos. Estes eventos, quando ocorrem, recebem uma exposição massiva na mídia, distorcendo os números que confirmam que a probabilidade de morte em um acidente aéreo é infinitamente menor do que um acidente rodoviário.

A recuperalidade de exemplos seria uma razão importante para justificar o fato de haver, por exemplo, concentração de postos de gasolina em um mesmo cruzamento. Ou mesmo justificar a motivação para lojas focadas em público de alto poder aquisitivo se instalarem em uma mesma rua. "Uma razão importante para esse

\footnotetext{
19 "Its is a common experience that the subjective probability of traffic accidents rises temporarily when one sees a car overturned by the side of the road".
} 
modelo é que os consumidores aprendem a localização de um tipo particular de produto ou loja e organizam suas mentes segundo essa localização.” (BAZEMAN, 2004, p.22). O lojista que deseja ser sempre lembrado acaba migrando para determinado centro comercial.

Efetividade do contexto da procura - este viés ocorre em situações em que a freqüência de determinado evento é avaliada baseada na disponibilidade de contextos em os eventos ocorrem. Tversky e Kahneman (1974) exemplificam este viés da seguinte forma: uma pessoa necessita avaliar a frequiência com que palavras abstratas e concretas aparecem na língua inglesa escrita. Uma forma natural para avaliar o caso seria procurar contextos em que as palavras poderiam aparecer. Seguindo a hipótese que contextos em a palavra "amor" apareça (como estórias de amor) são mais facilmente lembrados do que contextos envolvendo palavras concretas (como porta), palavras abstratas serão julgadas como mais numerosas do que palavras concretas.

Imaginação - Tversky e Kahneman (1974) exemplificam esse viés com o exemplo de uma expedição de aventura que necessita avaliar os possíveis riscos baseados na ocorrência de eventos incertos e absolutamente desconhecidos. Caso cenários com excessivo nível de periculosidade seja desenhado pelo grupo de aventureiros, a expedição pode parecer excessivamente perigosa, e mesmo assim o risco concreto de cada possível desastre pode estar mal dimensionado. Além disso, a probabilidade de risco da expedição pode ser subdimensionada caso possíveis situações envolvendo catástrofes não sejam imaginadas pelo grupo.

Correlação ilusória - é um viés que acontece quando pessoas avaliam a freqüência com que dois eventos acontecem fortemente correlacionados. Tversky e Kahneman (1974) ressaltam que pessoas, ao julgar a freqüência de ocorrência de dois eventos acontecerem concomitantemente, são influenciadas pela disponibilidade de exemplos concomitantes presentes em nossa mente. Assim, uma pessoa que conhece muitos usuários de maconha que são delinqüentes pressupõe que a maconha é diretamente relacionada à delinqüência (BAZEMAN, 2004). Aplicando este viés no mundo das finanças, sabemos que não é difícil encontrar pessoas que, por conhecerem muitos exemplos de pessoas bem sucedidas na bolsa de valores, passam a minimizar o real risco inerente à operação. 
c. Ancoragem

Ajuste insuficiente da âncora - Tversky e Kahneman (1974), em estudo, solicitaram a participantes que estimassem a porcentagem de países africanos nas Nações Unidas. Para cada participante foi dado um número aleatório como ponto de partida. Então solicitava-se aos participantes que mencionassem se a quantidade real era maior ou menor do que esse valor aleatório. Descobriu-se que os valores arbitrários da roleta tinham um impacto substancial sobre as estimativas. O número aleatório teve efeito de ancora sobre os entrevistados, passando a ser sua referência, mesmo não tendo qualquer significado.

Vieses de eventos conjuntivos e disjuntivos - segundo Tversky e Kahneman (1974), pessoas superestimam a probabilidade verdadeira de ocorrência de eventos múltiplos, ao passo que subestimam a probabilidade real de ocorrência de eventos que ocorrem independentemente.

Esse viés seria uma explicação para o constante atraso de cronograma de projetos que envolvem um planejamento com múltiplas etapas. "Indivíduos, empresas e governos com freqüência são vítimas do viés dos eventos conjuntivos em termos de cronograma e orçamento. Projetos de reforma da casa, investimentos em produtos novos e obras públicas raramente terminam conforme a programação [...]." (BAZEMAN, 2004, p. 39).

Excesso de confiança - "A maioria de nós confia excessivamente em suas capacidades de estimativa e não reconhece a verdadeira incerteza." (BAZERMAN, 2004, p.42).

Tversky e Kahneman (1974) explicam o excesso de confiança em termos de ancoragem. Especificamente, eles argumentam que, quando se solicita a indivíduos que estabeleçam uma faixa de confiança ao redor de uma resposta, sua estimativa inicial funciona como uma ancora que causa um viés na sua estimativa dos intervalos de confiança. 


\subsubsection{Efeitos de estruturação}

Por trás da análise das tomada de decisão em condições de risco, há forte influência da teoria da utilidade. "Quando confrontado com uma escolha, o tomador de decisão racional preferirá a perspectiva que ofereça a mais alta utilidade esperada." (TVERSKY, KAHNEMAN, 1981, p. 453) ${ }^{20}$.

De acordo com a teoria da utilidade, a utilidade de um resultado é ponderada por sua respectiva probabilidade. Porém há casos em que a preferência das pessoas sistematicamente violam este princípio.

"Markowitz [...] notou a presença de risco nas tomada de decisão [...]. Seus estudos, no entanto, não tratam do princípio da expectativa; dessa forma não podem considerar as diversas violações deste principio." (KAHNEMAN, TVERSKY, 1979, p. 276, grifo meu $)^{21}$.

[...] escolhas racionais requerem que a preferência entre opções não deve mudar com mudanças na estruturação. Devido a imperfeições da percepção e decisão humana, no entanto, mudanças de perspectiva geralmente alteram o tamanho relativo de objetos e o desejo relativo de opções. (TVERSKY, KAHNEMAN, 1981, p. 453, grifo meu) ${ }^{22}$.

Tais inconsistências fariam com que indivíduos, na prática, eventualmente escolhessem uma opção que não tivesse necessariamente o maior valor esperado e a menor variância.

Neste sentido, Kahneman e Tversky (1979) desenvolveram a chamada prospect theory, ou teoria perspectiva, demonstrando que indivíduos exibem preferências

\footnotetext{
20 "When faced with a choice, a rational decision-maker will prefer the prospect that offers the highest expected utility.”

21 "Markowitz [...] noted the presence of risk seeking in preferences [...] His treatment, however, retains the expectation principle; hence it cannot account for the many violations of this principle."

22 "[...] rational choice requires that the preference between options should not reverse with changes of frame. Because of imperfections of human perception and decision, however, changes of perspective often reverse the relative apparent size of objects and the relative desirability of options."
} 
incompatíveis com a teoria da utilidade, violando sistematicamente princípios de consistência e coerência e conseqüentemente alterando a avaliação das opções.

Apesar de valores subjetivos diferirem de um indivíduo para outro, os autores propuseram que a função valor possui de forma geral a forma $S$, conforme ilustrada no gráfico 9.

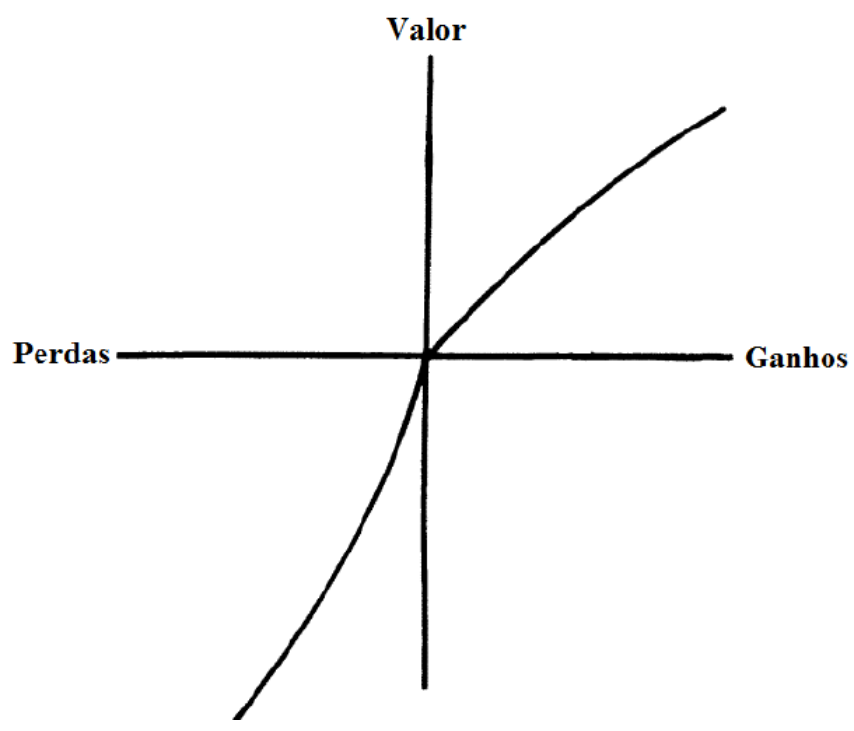

Gráfico 9- Uma função de valor hipotético

Fonte: Kahneman e Tversky, 1979, p. 279

Dessa forma, temos que a diferença em valor subjetivo entre um ganho de USD 10 e USD 20 é maior do que a diferença subjetiva entre um ganho de USD 110 e USD 120. A mesma relação entre diferença de valores acontece para valores negativos. Os autores ainda destacam que, de acordo com curva $S$, a resposta para perdas é mais extrema do que a resposta à ganhos. "O desprazer associado à perda de um determinado valor é geralmente maior do que o prazer associado com o ganho do mesmo montante.” (TVERSKY, KAHNEMAN, 1981, p. 454) ${ }^{23}$.

Os autores exemplificam a teoria com o exemplo de duas tomadas de decisão, cada uma contendo duas alternativas.

Decisão 1: 23 "The displeasure associated with losing a sum of money is generally greater than the pleasure
associated with winning the same amount [...]" 
a) Ganho certo de USD 240;

b) $25 \%$ de chance de ganhar USD 1000 e $75 \%$ de chance de auferir ganho nulo;

Decisão 2:

c) Perda certa de USD 750;

d) $75 \%$ de chance perder USD 1.000 e $25 \%$ de gozar de perda nula;

Para a primeira situação, a maioria dos indivíduos (84\%) optou pela primeira opção (a), ou seja, uma perspectiva menos arriscada é preferível a uma perspectiva de igual ou maior valor esperado, porém mais arriscada.

Em contraste, para a decisão 2 a maioria os indivíduos (87\%) optou pela opção mais arriscada (d), ou seja, uma perspectiva mais arriscada é preferível a uma perspectiva menos arriscada de igual valor esperado.

Cabe salientar que, em termos de julgamento de risco, investidores tendem não a olhar o nível de riqueza acumulada no final de um processo, mas a ganhos e perdas relativas a um ponto de referência. O caminho pode ser mais importante do que o ponto final de chegada.

Considerando especificamente o risco, os indivíduos tendem a se comportar com aversão a risco (loss aversion), alocando se forma assimétrica uma maior preocupação com a possibilidade de perdas do que ganhos (CUNNINGHAM, 2002).

\subsubsection{Mercados ineficientes}

Como visto anteriormente, a HME parte do pressuposto que a igualdade entre preço e valor seria esperada devido à arbitragem praticada por agentes racionais. Assim, há dois relevantes pressupostos que permeiam a base da HME. O primeiro assume que os mercados são operados por agentes que atuam sob racionalidade ilimitada, representativos do mercado, e que tomam decisões de acordo com a teoria da utilidade esperada, formando expectativas não-enviesadas. O segundo assume que qualquer tipo de discrepância entre o preço de um ativo e seu valor fundamental seria uma distorção episódica causada pela ação de noise traders. Essas anomalias 
seriam instantaneamente percebidas pelos agentes racionais, que a corrigiriam por meio do mecanismo de arbitragem - uma estratégia de investimento que ocorre quando um investidor racional (também chamado neste contexto de arbitrador) aproveita desvios momentâneos dos preços de ativos em relação à seu valor fundamental, conduzindo os preços de volta ao equilíbrio e auferindo ganhos sem que haja risco ou custos adicionais para o agente racional.

A HME implicaria, entre outros resultados, que mudanças nos preços refletiriam apenas novas informações, que os volumes de transação nos mercados financeiros seriam modestos, que os preços dos ativos financeiros apresentariam uma trajetória aleatória, e que os indivíduos diversificariam seus portfólios. Acumulam-se, entretanto, evidências sobre o irrealismo dessa hipótese e de suas previsões: os portfólios são pouco diversificados, os fundos de ações são ativamente administrados, há discrepâncias persistentes entre preços de mercado e valores baseados em fundamentos [...]. (ALDRIGHI, LIMANEZ, 2005, p.63).

Com relação ao pressuposto da racionalidade ilimitada, os teóricos das finanças comportamentais tratam das limitações que impedem o ser humano de tomar as decisões ótimas que o modelo racional pressupõe. “[...] alguns fenômenos financeiros podem ser entendidos de uma melhor forma usando modelos em que alguns agentes não são totalmente racionais." (BARBERIS; THALER, 2003, p. $1053)^{24}$

Bazeman (2004) detalha motivos que gerariam o desvio da conduta esperada, focando em limitações do próprio ser humano. O autor destaca que capacidade de decisão dos indivíduos pode ser limitada por fatores inerentes à assimetria de informações, como falta de informações, restrições de tempo e custo, bem como problemas referentes ao próprio ser humano, como limitada capacidade de absorção de informações, ou a própria limitação da inteligência do indivíduo.

Embora a estrutura restringida pela racionalidade considere que os indivíduos tentam tomar decisões racionais, ela reconhece que muitas

\footnotetext{
24 "[...] some financial phenomena can be better understood using models in which some are agents not fully rational."
} 
vezes falta aos tomadores de decisões informações importantes [...]. Restrições de tempo e custo limitam a quantidade e a qualidade das informações disponíveis. Além disso, os tomadores de decisões retêm somente uma quantidade relativamente pequena de informações [...]. Finalmente, limitações de inteligência e de percepções restringem a capacidade de os tomadores de decisões identificarem a solução[...]. (BAZEMAN , 2004, p.6, grifo meu).

Com relação à premissa da arbitragem, Barberis e Thaler (2003) questionaram essa hipótese de ganhos sem riscos. Para os autores, quando um ativo apresenta discrepâncias entre o seu valor e seus fundamentos, as estratégias utilizadas pelos arbitradores para retomar o equilíbrio podem ser arriscadas e custosas, tornando a opção de arbitragem pouco atrativa para os investidores racionais.

Dentre os riscos a que os arbitradores estão expostos, destacam-se: (BARBERIS, THALER 2003):

- O risco fundamental do ativo: A pouco provável existência de um ativo substituto perfeito gera riscos para a operação. Imagine uma situação em que o investidor compre uma ação da Ford, que imediatamente sofre uma queda de preço baseada em seus fundamentos. Como o arbitrador tem pleno conhecimento desta possibilidade, ele pode comprar ao mesmo tempo uma ação da General Motors para remover todo o risco fundamentalista $O$ problema é que as ações não são necessariamente perfeitamente substitutas e, na prática, somente parte do risco fundamental do ativo será eliminado.

Manter uma posição vendida em ações da General Motors protege o arbitrador, de alguma forma, de adversidades relacionadas à indústria automobilística como um todo, mas ainda mantêm ele vulnerável à novidades específica da Ford - novidades sobre pneus defeituosos. ${ }^{25}$ (BARBERIS, THALER, 2003, p.1056).

- O risco de investidores irracionais (Noise Traders risk): É o risco de que uma distorção de preços já detectada pelos arbitradores piore no curto prazo. As

25 " [...]Shorting General Motors protects the arbitrageur somewhat from adverse news about the car industry as a whole, but still leaves him vulnerable to news that is specific to Ford - news about defective tires." 
distorções fundadas em comportamentos irracionais e pessimismo exacerbado podem aumentar caso os referidos comportamentos não cessem. Nesta situação, o momento em que as distorções cessem - e elas podem na verdade piorar - não poderá ser estimado com precisão, gerando riscos de perda ao arbitrador que optar por sair no momento de baixa. Tal situação desestimularia a ação de arbitragem.

- Os custos de implementação: Custos de transação como comissões, taxas, diferença entre os preços de compra e de venda de um título (bidask spread), entre outros, podem tornar menos atrativo explorar as eventuais distorções existentes no mercado.

Shleifer e Vishny (1997) ainda chamam atenção para o problema de agência. Os autores ressaltam que, em um mercado representando por um grande número de pequenos arbitradores, cada um tomando uma posição pequena em um mercado mal precificado, a ação coletiva poderia de fato levar os preços a seu valor fundamental. Para os autores, o problema é que este pequeno arbitrador não é a figura dominante no mercado, onde investidores altamente qualificados estão por trás das grandes transações. “A característica fundamental deste tipo de arbitragem é que cérebros e recursos estão separados por uma relação de agência." $\left(\right.$ SHLEIFER,VISHNY, 1997, p.36) ${ }^{26}$.

\subsection{Discrepância comportamental na prática - O disposition effect}

O termo disposition effect - ou efeito disposição - surgiu em decorrência de um artigo de Shefrin e Statman (1985), desenvolvido com o intuito de estudar o comportamento de investidores individuais. Os autores verificaram um viés comportamental que afeta investidores na tomada de decisão em condições de incertezas. Conforme evidenciado nos estudos anteriores relacionados à teoria perspectiva, esses investidores apresentavam dificuldade para realizar perdas.

Assim, esses investidores possuem propensão de vender muito rapidamente ações que se valorizam - ganhadoras. Em contrapartida, há propensão de manter ações

\footnotetext{
26 "The fundamental feature of such arbitrage is that brains and resources are separated by an agency relationship."
} 
cujo preço cotado em bolsa tenha caído - perdedoras. Ou seja, o efeito disposição refere-se à tendência dos indivíduos de realizar ganhos no período mais curto possível, vendendo rapidamente aos ativos, ao passo que as perdas são mantidas por longo período, em uma irracional esperança de reversão da tendência.

Alguns motivos justificam a venda de ativos que perdem valor e a manutenção dos que ganham. Goldberg e Nitzsch (2001) afirmam que, se assumirmos que a probabilidade de aumentos nos preços dos ativos é maior durante um movimento de alta, e que quedas maiores podem ser esperadas após uma contínua tendência de queda, seria melhor desfazer-se imediatamente de um ativo na ocorrência de uma perda e manter o ativo comprado em caso de aumento de preço. Por outro lado, afirmar a existência de uma tendência de queda ou de alta com base nos preços de mercado dos ativos é uma tarefa bastante complexa, nem sempre óbvia, e associada ao tempo que o investidor possui para manter seu ativo em carteira.

Shefrin e Statman (1993) e Goldberg e Nitzsch (2001) citam padrões de conduta que são observados nos investidores. Esses padrões estabelecem limites de perdas no valor de ativos que os investidores estão dispostos a tolerar. Alguns estabelecem que seus ativos serão vendidos se caírem mais que 10\%. Outros estabelecem limites menores.

A manutenção de ativos "ganhadores" na carteira, bem como a realização mais rápida das perdas, pode ser vantajosa mesmo na ausência de vantagens fiscais. Odean (2000) mostrou indícios de que ativos ganhadores que são vendidos apresentam um ganho aproximado de 3,4\% superior ao dos ativos que são mantidos na carteira de investidores dos EUA por um período estudado de 18 meses após a venda. Considerando as vantagens fiscais o retorno para o investidor seria superior em $4,4 \%$ caso os ativos perdedores fossem vendidos.

Há evidências empíricas desse efeito, além das evidências experimentais. Shefrin e Statman (1993) e Odean (2000) sugerem que os investidores individuais possuem a tendência de vender ativos "ganhadores" e manter ativos "perdedores" de janeiro à novembro em todos os anos. Odean (2000) acrescenta que isso ocorre por razões comportamentais e não por razões racionais. 
Também foram feitas pesquisas sobre o disposition effect fora dos Estados Unidos. Grinblatt e Keloharju (2000) realizaram pesquisas com investidores finlandeses; Shapira e Venezia (2001) com israelenses; Brown, Rosa e Walter (2002) com australianos.

Genesove e Mayer (2001) observaram a tendência ao disposition effect também no mercado imobiliário, constatando que os vendedores procuram não vender seus imóveis quando ocorre perda de valor.

Frazzini (2006) registra o disposition effect em gestores de fundos de investimento, especialmente os "perdedores", que chegam a apresentar índices desse efeito tão altos quanto investidores individuais. $\mathrm{O}$ autor também afirma que esse efeito leva a uma demora na reação a novas informações que diminuam o valor dos ativos, implicando na maior previsibilidade de retornos.

A existência desse efeito não é questionada por nenhum dos autores que escreveram sobre o assunto. As motivações que levam ao efeito, no entanto, causam mais polêmica e discussões. Alguns autores sugerem que o disposition effect pode ser justificado com pressupostos racionais, enquanto outros sugerem que esse efeito está de acordo com as teorias comportamentais citadas neste trabalho.

Alguns autores estudaram os efeitos psicológicos mais relevantes para a compreensão do chamado disposition effect. Shefrin e Statman (1993), Barberis e Thaler (2003), Goldberg e Nitzsch (2001) e Shiler (1999) fizeram as primeiras contribuições sobre o tema analisando a comportamento dos agentes segundo a teoria do prospect theory.

\subsection{Behavioral finance e regulação do mercado financeiro}

Diferentemente da teoria neoclássica - que parte do pressuposto que os agentes baseiam suas decisões em argumentos racionais - a finanças comportamentais parte do pressuposto que agentes não tomam decisões racionais a todo instante, sofrendo de vieses que alteram os resultados finais esperados. 
Esse tipo de viés comportamental afeta todo tipo de investidor, incluindo o chamado investidor profissional - agentes ativos atuantes no mercado financeiro, com experiência e formação profissional adequada para a o desempenho da profissão.

A grande crise financeira, que assolou o mundo em 2008, surpreendeu grande parte dos analistas financeiros envolvidos com análises diárias sobre o mercado. $\mathrm{O}$ recente histórico de alta rentabilidade nas operações pode ter, de alguma forma, induzido a um excesso de confiança em grandes players do mercado, culminando no impensável processo de bancarrota de tradicionais instituições, como o Lehman Brothers, Bearing Sterns ou AIG.

De acordo com Canuto e Lima (2001), o trabalho de regulamentação é fundamental para a correção de ineficiências inerentes ao mercado, sendo inclusive aplicável a países com mercados financeiros menos eficientes.

No entanto a importância da regulação como forma de mitigação das ineficiências de mercado não é consenso. Na opinião de Cunningham (2002), uma forma mais adequada de reduzir as irracionalidades próprias do mercado seria por meio da educação do investidor, em detrimento da pura imposição de regras. 


\section{REGULAÇÃO DO RISCO PARA MERCADOS FINANCEIROS}

\subsection{A Evolução da regulação bancária}

Bancos, bem como qualquer outra instituição que trabalhe com gestão de portfólios e participação no sistema de pagamentos, possuem especial autonomia para criar crédito, afetando conseqüentemente o nível de liquidez da economia (Lima, 2005).

Dado que operações que envolvam crédito geram um tipo de ativo muito pouco líquido para as instituições - ou com liquidez condicionada a um desconto sobre seu valor efetivo - mas ao mesmo tempo financiado por depósitos que são resgatados de forma geral no curtíssimo prazo, essas instituições trabalham com um elevado grau de alavancagem operacional. Em situações de redução na liquidez no mercado, e conseqüente redução no nível de depósitos, essas instituições sofrem de elevado risco de solvência, o que pode comprometer de forma drástica a continuidade das operações. Assim, a adequação do nível de capital adequado para o risco assumido por uma instituição financeira é fundamental para a solidez dos mercados.

A adequação de capitais ajustado pelo risco não é algo verdadeiramente novo na esfera das finanças internacionais. Porém Kregel (2006) ressalta que índices formais de capital não compuserem formalmente parte das questões relacionadas à regulação bancária até os primórdios da década de 1980, momento em que diversas mudanças econômicas motivaram a evolução da regulação bancária de forma mais estruturada e formal.

Neste contexto, o autor aponta, como principal fator motivador da evolução da regulação bancária, a crescente crença em países como os Estados Unidos, da eficiência das forças de mercado - regulação baseada no mercado - como fator suficiente para a adequada regulação dos mercados de capitais e monetário. Tal posicionamento era expressado com ações como a supressão do controle sobre as taxas de juros, permitindo o livro arbítrio no mercado. Assim, a imposição de padrões de capital teria o papel de dar maior responsabilidade aos bancos para determinar o custo do capital bancário, e conseqüentemente o custo das taxas de empréstimos. 
Como segundo fator, o autor ressalta o crescente aumento da demanda por empréstimos bancários no mercado internacional, reduzindo drasticamente o índice de capital de instituições financeiras americanas. Em algumas situações abaixo de $2 \%$, aumentando a pressão pelo aumento das exigências de adequação de capital.

E finalmente, Kregel ressalta o colapso do sistema financeiro internacional baseado no Acordo de Bretton Woods no início da década de 1970, momento em que os Estados Unidos não puderem mais conter a convertibilidade do dólar à paridade fixa acordada, gerando um expressivo aumento da volatilidade das taxas de juros e câmbio.

Em agosto de 1971, a administração Nixon fechou a janela do ouro, encerrando a conversibilidade do dólar. Em fevereiro de 1973, forçou a economia mundial a renunciar ao sistema de Bretton Woods de taxas de câmbio fixas e partir para câmbios flutuantes. [...] Daí em diante, o nível relativamente alto de cooperação econômica internacional alcançado contra o pano de fundo de grande expansão econômica pósguerra cederia, cada vez mais, a um sempre intensificado conflito político-econômico internacional [...], em especial quanto as regras do jogo para o investimento, o comércio e o dinheiro internacionais. (BRENNER, 2003, p.68-69, grifo meu).

Diante deste conflito, Brenner ressalta que o governo americano buscou aumentar a mobilidade do capital, concedendo forte apoio à internacionalização dos bancos locais. Este contexto de maior liberdade dos bancos permitiu a ocorrência das chamadas operações fora do balanço - off-balance sheet.

Para Lima (2005), o processo de liberalização financeira e globalização - e a tendência de integração dentro de um mesmo conglomerado financeiro de atividades bancárias e não bancárias - também teve como consequiência uma inédita situação de concorrência entre bancos americanos, europeus e japoneses. $\mathrm{O}$ autor ressalta que a maior fragilidade nessa disputa apontava para os bancos americanos, que "envolvidos por crises, e limitados nas suas escolhas de diversificação de atividades pela Lei Glass/Steagal.” (LIMA, 2005, p.133).

Bancos americanos se viam assim em desvantagens competitivas; seja por questões ligadas a legislação local (Glass/Steagal); seja por questões próprias típicas do setor 
no país, como a característica de operar com capital próprio em nível superior aos europeus e japoneses, que "operavam praticamente apenas com recursos de terceiros.”(CARVALHO, 2005, p.134).

Neste contexto de iminente crise sistêmica, as "exigências de capital eram o instrumento regulatório menos intrusivo para lidar com os diferentes sistemas nacionais e de regulamentação financeira.” (KREGEL, 2006, p.26).

Em 1988, fruto de um trabalho conjunto do G7 reunidos no Comitê de Basiléia, elabora-se o Acordo de Capital de Basiléia, visando estabelecer normas prudenciais que objetivavam reduzir os diferencias competitivos de mercados situados em países com regras mais flexíveis.

\subsection{Basiléia I: Tratamento para o Risco de Crédito}

O Acordo de Basiléia I foi constituído em um período de grande turbulência econômica, após o fim do Acordo de Bretton Woods, no início dos anos 1970. Os anos seguintes ao fim do Acordo foram marcados pela grande liberalização financeira e a ocorrência de grandes crises internacionais - notadamente os dois choques do petróleo as crises da dívida da América Latina, iniciadas a partir da crise do México de 1982.

Este período de turbulência e crises mundiais trouxe grande deterioração do capital dos bancos, especialmente nos EUA. O contexto histórico da deteriorização das adequações de capitais dos bancos nos EUA remonta, segundo Kregel (2006), desde a criação do Sistema Bancário Nacional, na década de 1860. Mitchell (apud KREGEL, 2006, p. 27) aponta quedas nas proporções capitais/passivos de 35\% em 1864, reduzindo a proporção para 18\% em 1909. Cooke (apud KREGEL, 2006, p.27) aponta redução nos índices de 15\% em 1920 para 5,5\% em 1945.

Apesar da drástica queda histórica nos índices de capitais e do incremento eminente do risco no setor bancário, as primeiras ações foram apenas tomadas em 1981, momento em que Paul Volcker superou a resistência dos bancos privados e introduziu o primeiro índice numérico de adequação mínima de capital, estipulado 
em 5\% para capital primário e 5,5\% para capital total. Porém, os dezessete maiores bancos que operavam em mercados internacionais foram excluídos das imposições, sobre a alegação de possuir um maior acesso a liquidez, bem como gozar de maior confiança no mercado.

Em 1974 foi criado pelos países do G-10 o Comitê de Supervisão Bancária da Basiléia - BCBS, da sigla em inglês Basel Committe on Banking Supervision. O Comitê se reúne regularmente quatro vezes por ano no Banco de Compensações Internacionais (BIS - Bank for International Settlements), funcionando como um fórum de discussão. Um de seus principais objetivos é promover uma padronização de regras e procedimentos a serem seguidos pelos bancos atuantes nos países membros, fortalecendo a solidez dos sistemas financeiros.

Atualmente os países membros do comitê representam Argentina, Austrália, Bélgica, Brasil, Canadá, China, França, Alemanha, Hong Kong, Índia, Indonésia, Itália, Japão, Coréia, Luxemburgo, México, Holanda, Rússia, Arábia Saudita, Singapura, África do Sul, Suécia, Suíça, Turquia, Reino Unido e Estados Unidos. Os países são representados por seu respectivo Banco Central, ou autoridade responsável pela supervisão prudencial sobre bancos.

Finalmente em 1988 o Comitê divulgou o documento final "International Convergence of Capital Measurement and Capital Standards", ou convergência internacional para mensuração e adequação de capital, cuja implementação foi concluída nos países do G-10 em 1992.

Segundo o referido documento, os dois principais objetivos do acordo era, primeiramente, fortalecer a estabilidade do sistema financeiro mundial; e, em segundo lugar, que as novas diretrizes deveriam ser justas e conter um alto grau de consistência em sua aplicação para bancos em diferentes países de forma a diminuir a existente fonte de desigualdade na competição entre bancos internacionais.

Assim, o Acordo de Capital de Basiléia visava:

I) Reduzir o risco de fracasso dos bancos;

II) Garantir liquidez ao Sistema Financeiro Internacional;

III) Padronizar normas aplicáveis as instituições financeiras; 
IV) Estabelecer limites operacionais para os bancos com operações internacionais;

"O acordo de Basiléia de 1988 consistirá principalmente na transformação da exigência de capital próprio numa norma regulatória aplicável a todos os competidores." (CARVALHO, 2005, p.134). Na prática foi introduzida no país uma métrica de ponderação de risco, exigindo-se um nível mínimo de capital para cobrir os riscos das operações e garantir a solvência das instituições financeiras. Carvalho (2005) salienta que a norma era voltada apenas aos bancos internacionalmente ativos, como forma de garantir condições igualitárias de competição. O acordo era aplicável exclusivamente a bancos comerciais.

O que aconteceu efetivamente foi uma transformação muito mais abrangente do que a esperada na medida que, não apenas os países do G10 adotaram as recomendações, mas todo o setor bancário mundial também o fez. "Em outras palavras, o acordo passou de um acerto de regras competitivas para um marco na reorientação das estratégias de regulação prudencial no final do século XX". (CARVALHO, 2005, p.134).

As normas foram assim adotadas por todos os países considerados desenvolvidos e por boa parte dos países emergentes e em desenvolvimento. No final da década de 1990 o FMI e o Banco Mundial tornaram a adesão ao Acordo o critério principal de avaliação de solidez financeira dos países-membros.

Como valor referencial mínimo de reserva de capital, foi estipulado a exigência de que as instituições mantivessem $8 \%$ da soma total de seus ativos. Este valor mínimo poderia, no entanto, ser substancialmente modificado de acordo com o grau de riscos das operações. Dessa forma, Basiléia I estipulou que a soma de cada ativo para o cálculo final deveria ser ponderada em função do risco corresponde de cada ativo. "O acordo original, o chamado Basiléia I, foi um marco, não apenas pela busca de harmonização regulatória, mas também pela distinção entre os tipos de ativos por risco." (LIMA, 2005, p.195).

Para isso, foram criadas faixas de riscos, compondo assim o APR - Ativo Ponderado pelo Risco. Para o cálculo do APR, os ativos foram agrupados em 4 faixas distintas, com ponderação, com percentuais variando entre 0\%, 20\%, 50\% e $100 \%$. Derivativos negociados em bolsa ficaram originalmente de fora das 
recomendações do Acordo, dado que os agentes participantes dessas operações assumissem o risco de crédito.

Dessa forma, na prática, um ativo que apresentasse risco ponderado de $0 \%$, implicaria uma alocação de capital nula, assim como um ativo que apresentasse um risco ponderado de $50 \%$ exigiria uma alocação de capital de $4 \%$ do seu valor, ou seja, metade da exigência mínima de capital fixada em $8 \%$.

O quadro 1 detalha a classificação dos ativos por faixa de risco, de acordo com a proposta apresentada no documento original.

\begin{tabular}{|c|c|c|}
\hline Fator & Risco & Ativos a serem ponderados \\
\hline $0 \%$ & Risco Nulo & $\begin{array}{l}\text { - Créditos contra governo (somente aqueles membros da } \\
\text { OECD - Organização para Cooperação e Desenvolvimento Econômico) } \\
\text { - Crédito contra banco central, em moeda nacional } \\
\text { - Caixa e ouro }\end{array}$ \\
\hline $20 \%$ & Risco Reduzido & $\begin{array}{l}\text { - Créditos contra bancos sediados em países da OECD } \\
\text { - Crédito contra bancos multilaterais de desenvolvimento } \\
\text { - Créditos contra bancos sediados em países fora da OECD, com prazo } \\
\text { de até um ano }\end{array}$ \\
\hline $50 \%$ & Risco Reduzido & - Financiamentos imobiliários (residencial) \\
\hline $100 \%$ & Risco Normal & $\begin{array}{l}\text { - Créditos de governos (não membros da OECD) } \\
\text { - Créditos contra bancos sediados em países fora da OECD, } \\
\text { - Créditos contra o setor privado } \\
\text { - Créditos contra empresas comerciais do setor público } \\
\text { - Ativo permanente }\end{array}$ \\
\hline $\begin{array}{l}\text { A critério } \\
\text { Nacional } \\
(0,10,20 \text { ou } 50 \%)\end{array}$ & & $\begin{array}{l}\text { - Créditos contra instituições locais do setor público } \\
\text { com exceção do governo central e banco central }\end{array}$ \\
\hline
\end{tabular}

Quadro 1: Fatores de ponderação por categoria de ativos Fonte: BCBC, 1988, p.17-18.

Neto e Ribeiro (2006) ressaltam que a estrutura de Basiléia I é composta por três elementos: capital regulatório mínimo para tratamento de riscos, ponderação de riscos por classe de ativos e instrumentos e mecanismo off balance sheet.

Assim, o foco principal da Basiléia I é o tratamento ao risco de crédito das instituições financeiras. "O Acordo de Basiléia tem como um de seus principais objetivos o gerenciamento do risco e a exigência de capital como forma de fazer frente a perdas associadas a inadimplência.”(GUIMARAES, LIMA, 2010, p.208). 
Com a evolução da complexidade das operações, riscos de mercado e de derivativos também são considerados na abordagem proposta.

Ao introduzir essas mudanças descritas, a Acordo de Basiléia de 1988 impôs a prática de coeficientes de capital por países distribuídos em todos os continentes, criando assim um novo paradigma de regulação prudencial.

\subsection{Insuficiências do acordo da Basiléia I e a transição para um Novo Acordo}

As mudanças introduzidas por Basiléia I, apesar de apresentaram em sua essência o foco no incremento da estabilidade do sistema financeiro internacional, sofreram efeitos coletarias que passaram a minar os benefícios então aguardados.

O Acordo sofria assim de inúmeras limitações, sobretudo em relação à metodologia utilizada para o cálculo da exigência de capital:

Voltado para a administração do risco de crédito, o procedimento do comitê não consistiu apenas na prescrição de instrumentos de gestão de riscos, mas também na definição quantitativa daqueles riscos. Em outras palavras, o comitê não apenas criou instrumentos para gerir os riscos de crédito, como também calculou quais seriam os riscos envolvidos nas diversas operações de crédito, emitindo uma tabela onde a cada classe de ativos identificada correspondia uma medida de risco. Dada a diversidade de operações realizadas por um único banco, não deveria ser surpreendente a conclusão de que uma tabela produzida pelo comitê, ou por qualquer comitê, teria de ser extremamente grosseira e inexata. (CARVALHO, 2005, p.136, grifo meu).

Apesar da importância da avaliação do risco de crédito [...] o maior incentivo para as instituições financeiras desenvolverem novos modelos de risco de crédito talvez seja sua insatisfação com a imposição de exigências de capital para empréstimos pelo BIS e pelos BCs. A abordagem da Basiléia I foi vista como uma política de tamanho único, já que todos os empréstimos a contrapartes do setor privado estão sujeitos ao mesmo coeficiente de capital de 8\%. (GUIMARÃES, LIMA, 2010, p.213). 
Ao ponderar a exigência de reserva de capital pelo grau de risco de crédito, essa exigência objetivava incentivar os bancos a carregarem ativos de baixo risco ou reservarem maior volume de capital caso optassem por investir em operações mais arriscadas, almejando neste caso maior rentabilidade.

Na prática, a estratégia regulamentar baseada em uma tabela fixada por um órgão externo e voltada exclusivamente para o risco de crédito gerava mutações, como criação de estímulos aos bancos para gerenciar seu mix de serviços em direção aos mercados de títulos, sobre o qual não incidiam obrigações de natureza regulatória.

Em outras palavras, ao "punir" a atividade de crédito com o peso de regulações, deixando livre a operação nos mercados de papéis, o acordo estimulou os bancos a minimizarem seus custos operacionais privilegiando a participação nos processos de securitização. (CARVALHO, 2005, p.137).

Essas distorções geradas por uma regulação tutelar, cabendo a um órgão externo a mensuração de qual risco a instituição estaria sujeita, gerariam limitações e conseqüentemente novos ajustes nas regras.

A introdução de índices de capital nos Estados Unidos levou a arbitragem da diferença entre capital econômico e capital regulatório por meio de uma distribuição apropriada dos ativos no interior de cada categoria de ponderação de risco para maximizar os retornos de um dado nível de capital de risco. (KREGEL, 2006. p.33).

Segundo o autor, a chamada arbitragem regulatória acabou incentivando duas grandes mudanças nas operações dos bancos. A primeira mudança foi um drástico incremento de esforços em atividades que gerassem taxas e comissões em detrimento de operações que demandassem capital regulatório. A segunda mudança foi a criação de modelos de alocação de capital que objetivavam maximizar o retorno do capital para um dado nível de risco, gerando preocupações para os reguladores em relação ao potencial de risco destas atividades. 
Os bancos então perceberam que fazia muito pouco sentido se apegar a empréstimos relativamente seguros cujas alocações internas de capital refletindo o risco econômico estavam abaixo do requerimento de capital regulatório de $8 \%$. Os bancos poderiam se livrar desses empréstimos antes do vencimento através da securitização [...]. (GUTTMANN, 2006, p.180).

Para Lima (2005), a possibilidade de redução de requisitos regulatórios de capital sem a referente redução do grau de exposição de risco das instituições - situação alcançada por meio do incremento da sofisticação das operações bancárias - afetou de forma drástica a eficácia do Acordo de Basiléia I.

Por exemplo, a possibilidade de venda - ou outro deslocamento para fora do balanço - de ativos para os quais a avaliação, pelo banco, do capital adequado é menor do que a estabelecida pela regulação, deixando em carteira os ativos em situação oposta. A consequiência tende a ser registros de capital/ativos regulatórios abaixo dos que seriam economicamente adequados. (LIMA, 2005, p.196).

Para o autor, as inovações financeiras - como a possibilidade de securitização de empréstimos, derivativos de créditos, entre outros - ampliam as possibilidades para essas práticas, diminuindo a eficácia das diretrizes de capital mínimo até então exigidas.

A arbitragem de capital regulatório seguiu-se como estratégia cada vez mais viável e relevante, particularmente à medida que as novas tecnologias de mensuração de riscos, pelos bancos, permitiram maiores diferenças entre os requisitos por eles estimados como necessários e aqueles estabelecidos para ativos específicos pelos reguladores. (LIMA, 2005, p. 196, grifo meu).

Essas inovações financeiras geram uma enorme discrepância entre a complexidade das operações e o nível de risco reconhecido no Acordo, dirimindo a eficácia das proposições até então elaboradas.

De forma a agravar a situação, os $8 \%$ de capital regulatório exigido como reserva de capital ainda era mais baixo do que o requerimento interno de risco exigido 
pelos bancos para operações com alto grau de incerteza. Assim parecia fazer sentido para os bancos continuar mantendo empréstimos mais arriscados com um requerimento interno de capital.

[...] os bancos responderam a Basiléia I procurando maior risco e aprenderam, então, a viver com esse viés buscando proteção de risco por meio de uma outra inovação financeira importante, o uso de derivativos de crédito, que permitiu transferir o risco econômico para terceiros. As securitizações de empréstimos e os derivativos e crédito explodiram em volume durante a segunda metade da década de 1990, indicando um isso amplo de arbitragem regulatória entre os requerimentos de risco regulatório [...]. (GUTTMANN, 2006, p.180).

Lima (2005) ainda ressalta como insuficiência do Acordo a sua inabilidade em reconhecer os instrumentos de redução e gestão de risco, como os derivativos e a securitização de ativos, pecando assim por “[...] não premiar o uso e o aprimoramento de técnicas e instrumentos de gerenciamento de riscos." (LIMA, 2005, p.196).

A erosão crescente da eficácia das práticas introduzidas pela Basiléia I dispara assim a reforma do Acordo. Em 16 de janeiro de 2001, o Comitê da Basiléia lançou uma proposição para o novo Acordo de Capital da Basiléia, processo que incluiu a revisão do Acordo de 1988 de forma a desenvolver uma nova estrutura que propiciasse o fortalecimento do sistema bancário internacional. Dentre as principais recomendações, o novo Acordo buscou a adoção de práticas de administração de riscos mais sólidas, baseando-se não apenas na determinação de capital.

"O Novo Acordo de Basiléia foi criado para reduzir essa arbitragem regulatória." (KREGEL, 2006, p.33).

\subsection{Basiléia II}

Diante das fragilidades do Acordo de 1988, O Comitê da Basiléia apresentou uma proposta de reformulação das regras de ponderação de riscos. A nova proposta foi discutida junto aos supervisores dos países membros e instituições representativas 
dos bancos, como IIF (Institute of International Finance), expressando o interesse de mais de 300 instituições financeira.

O ciclo de debate em torno da proposta definitiva exigiu cerca de cincos anos de discussões, iniciadas em 1999 e estendidas até 2004, data da apresentação da versão final do Acordo. O novo Acordo, oficialmente denominado "Estrutura Revisada para o Capital Internacional" (Revised International Capital Framework) permitia os bancos elegíveis determinarem suas próprias exigências de capital, de acordo com seu próprio ativo. O objetivo era melhor adequar o capital regulatório ao capital econômico.

Após três versões prévias, em 2004 o BCBS publicou o documento "Novo Acordo de Capital da Basiléia" ("International Convergence of Capital Measurement and Capital Standards: A Revised Framework”), conhecida como Basiléia II.

Para o novo Acordo foi desenvolvido um maior detalhamento de classes de riscos de crédito e de mercado. E mais do que isso, o novo Acordo introduziu a exigência de alocação de capital direcionada especificamente para os riscos operacionais dos bancos, apresentando uma abordagem mais complexa e abrangente em relação ao risco efetivamente incorrido nas operações.

"Essa iniciativa, denominada Basiléia II, obriga os bancos a calcularem padrões mínimos de capitais mediante a avaliação regular dos riscos de crédito, de mercado e operacionais predominantes." (GUTTMAN, 2006, p.177).

Com essas modificações, há incentivo direto a melhorias de práticas de gestão de riscos nas instituições.

[...] Basiléia II propõe uma abordagem radicalmente diferente das avaliações de risco em comparação com a tosca ponderação uniformizada de risco de crédito realizada por seu predecessor. [...] a idéia é incitar os bancos a buscarem uma melhoria contínua na gestão de risco, ao mesmo tempo que se garanta que terão pelo menos um mínimo de cuidado com relação ao grau de risco de sua carteira. (GUTTMANN, 2006, p.182). 
Assim, o novo Acordo permitia aos bancos maior liberdade na escolha de métodos de avaliação de riscos, estendendo a possibilidade de o próprio banco definir e mensurar os riscos inerentes a sua operação, incluindo o risco de crédito. Ou seja, o tratamento do crédito bancário, que no Acordo de Basiléia I baseava-se em uma iniciativa tutelar, passa a ser baseado em incentivo.

Importante ressaltar que a alocação de capital correspondente ao risco da instituição é a base fundamental da Basiléia I e Basiléia II. Porém neste segundo momento feito com base em informações internas das instituições, baseados em seus sistemas próprios de avaliação de riscos (Internal Risk Based Approaches - IRB).

Segundo Lima (2005), “o objetivo seria eliminar a freqüente manutenção de dois conjuntos de registros, passando os parâmetros usados para o cálculo do capital regulatório a serem os mesmos que a direção utiliza para gerir o banco." (LIMA, 2005, p.197).

Essa liberdade variava de acordo com o grau de sofisticação das atividades exercidas pelos bancos e de seus controles internos. O objetivo final da mudança era permitir que os bancos ajustassem melhor seus cálculos de risco regulatório ao risco econômico, acabando assim com a arbitragem regulatória amplamente praticada no período vigente do primeiro Acordo.

"Os bancos que optarem pelas técnicas mais avançadas de mensuração de risco terão o benefício de utilizar menores exigências mínimas de capital, o que é um incentivo direto para o progresso nessa área.” (GUTTMANN, 2006, p.182).

Ao cálculo da exigência de capital mínimo exigido - capital regulatório - junta-se o processo de revisão pela autoridade monetária e a disciplina imposta pelo mercado (transparência), formando os três grandes pilares bases do novo Acordo. 
A figura 1 resume os principais pilares do Acordo de Basiléia II.

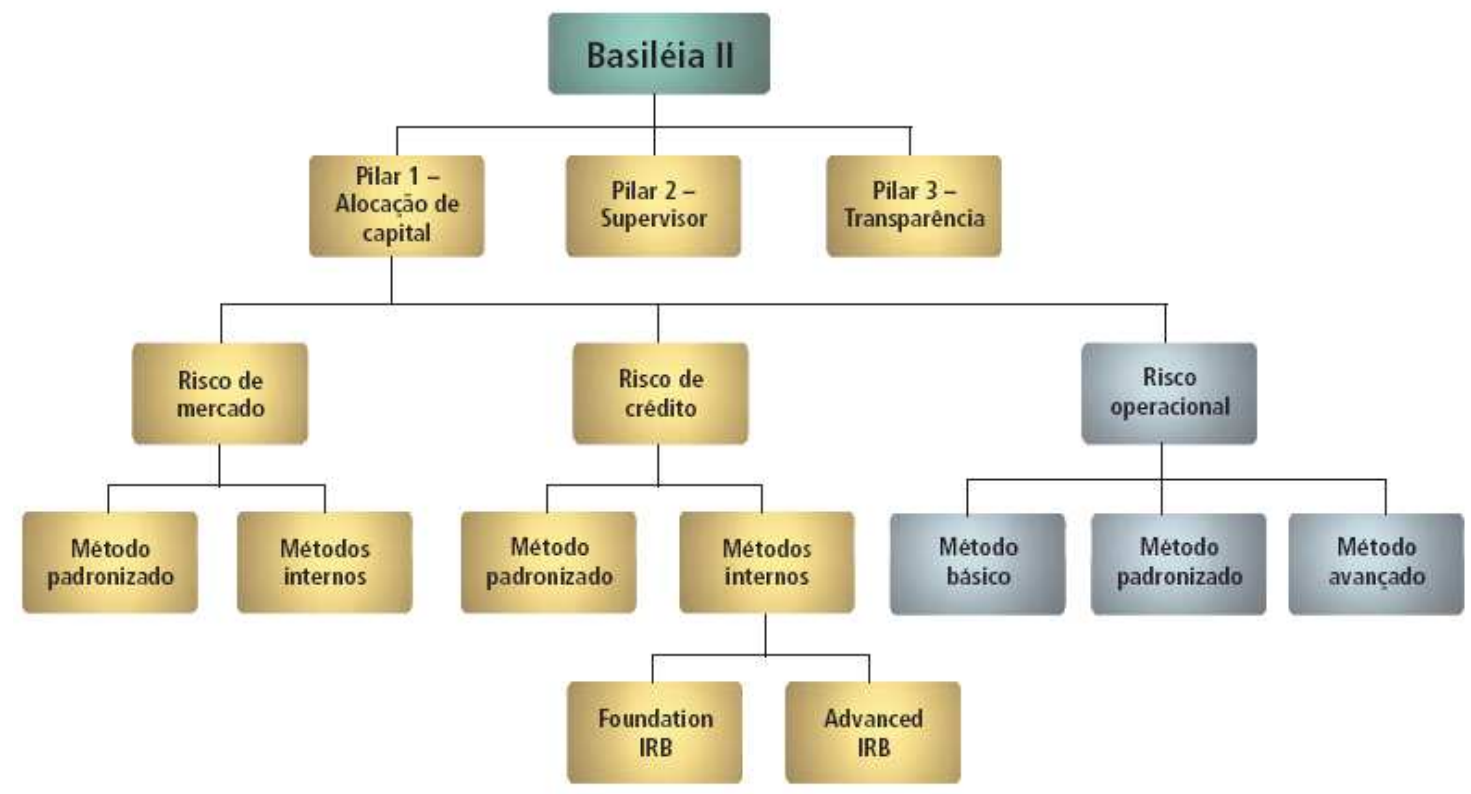

Figura 1: Os três pilares de Basiléia II

Fonte: Carvalho, D. e Caldas, M. ( s.d., p. 79)

a. Cálculo das exigências mínimas de capital

Para o cálculo das exigências mínimas de capital, considera-se o risco de crédito, de mercado e risco operacional. Em relação ao Acordo de 1988, Basiléia II adiciona uma abordagem específica para risco operacional e traz modificações na abordagem do risco de crédito, conforme detalhado na figura 2 .
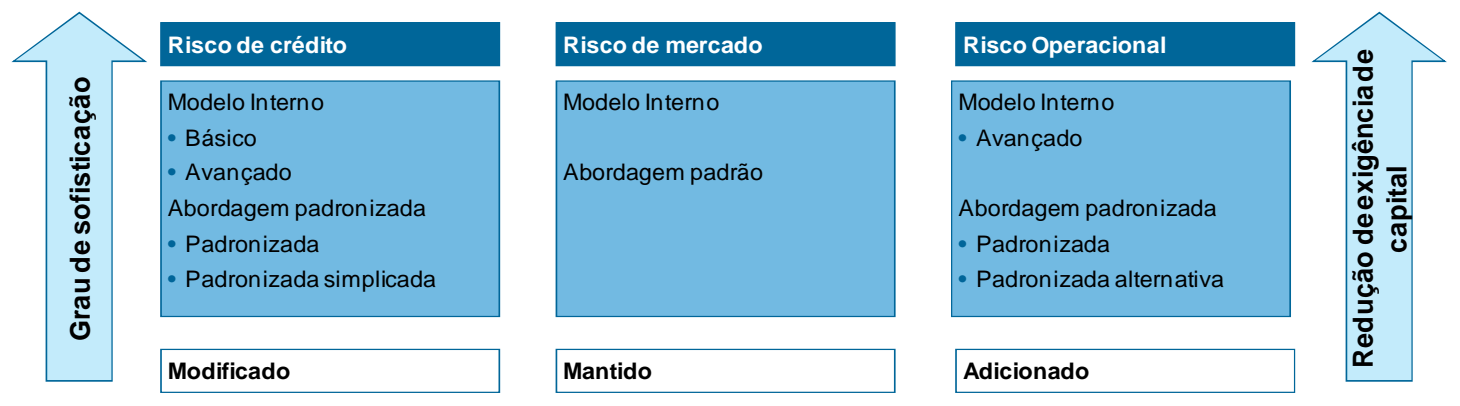

Figura 2: Pilar I - Alocação de capital Fonte: Elaborado pela autor. 


\section{Risco de crédito}

A Basiléia II apresenta três abordagens, de crescente nível de sofisticação, para o tratamento do risco de crédito, sendo uma delas a chamada abordagem padronizada, e as demais baseadas em modelos internos dos bancos - IRB (Internal Risk Based Approaches).

A abordagem padronizada, por ser baseada em categorias padronizadas de risco, apresenta semelhanças com as características de Basiléia I. De acordo com esta metodologia, não há exigências para que os bancos forneçam suas próprias informações de risco. Assim como no Acordo de 1988, cabe aos bancos “[...] designar suas exposições ao risco de crédito a partir de característica dos emissores dos instrumentos que compõem sua carteira de ativos, se emissores são agentes públicos, corporativos, soberanos, bancos comerciais, securities firms, entre outros." (NETO, RIBEIRO, 2006, p.319- 320).

Porém a ponderação de risco, na abordagem padronizada do novo Acordo, não é mais aplicada de maneira uniforme, abrindo espaço para a utilização de avaliações de riscos desenvolvidas por empresas tais como as agências privadas de risco. A abordagem padronizada é adequada para bancos de pequeno e médio porte, com formas menos complexas de empréstimos e controles internos menos robustos.

A inovação em relação ao primeiro Acordo é que nesta abordagem não se relaciona ponderações de riscos ao status legal dos tomadores, mas a probabilidade estimada de default, conforme detalhado no quadro 2.

\begin{tabular}{|c|c|c|c|c|c|c|}
\hline Rating & AAA a AA- & $\begin{array}{c}\text { A+ a } \\
\text { A- }\end{array}$ & $\begin{array}{c}\text { BBB+ a } \\
\text { BBB- }\end{array}$ & $\begin{array}{c}\text { BB+ a } \\
\text { B- }\end{array}$ & Inferior a B- & Sem Rating \\
\hline Fator de Ponderação & $0 \%$ & $20 \%$ & $50 \%$ & $100 \%$ & $150 \%$ & $100 \%$ \\
\hline
\end{tabular}

Quadro 2: Ponderação conforme o rating Fonte: BCBS, 2001.

Já os bancos com maiores exposições a risco, e metodologias de administração de risco mais avançadas, possuem duas opções adicionais, baseadas em sua própria avaliação interna de risco. São as chamadas abordagens de classificação interna 
(Internal Risk Based Approaches, IRB), podendo o banco optar por um estágio mais básico (Fondation) ou um estágio mais avançado (Advanced).

$\mathrm{Na}$ abordagem básica, os bancos necessitam apenas fornecer informações relativas às probabilidades de default. Já a abordagem avançada, reservada para instituições maiores e mais sofisticadas, permite que os bancos utilizem suas próprias estimativas de riscos relevantes. "O BIS, quer, evidentemente, encorajar o progresso da tecnologia de mensuração de risco e dar aos bancos incentivos para adotarem as técnicas que reflitam o estado das artes tão logo quanto possível." (GUTTMANN, 2006, p.184).

\section{Risco de mercado}

O risco de mercado, um tipo de risco advindo das flutuações no valor de mercado de uma carteira de títulos, e que portanto precisa de suporte de capital, também foi alvo dos reguladores. Segundo Guttman (2006), a inserção deste risco pelos reguladores foi consequiência de mudanças estruturais que levaram os bancos a manter enormes montantes de títulos (securities) em seus balanços - notadamente a tendência de criação dos chamados bancos universais, com operações comerciais e de banco de investimento unidas em uma mesma instituição.

Com essa nova tendência, bancos de investimento passaram a atuar em operações além de suas atuações típicas - brokers, dealers e subscritores de títulos - passando inclusive a administrar fundos de administradores institucionais, como os fundos mútuos, de pensão e companhias de seguros. Com ampla retenção de títulos, e em consequiência das possibilidades de perdas devido a flutuações nos preços desses ativos, os bancos passaram então a sofrer exposição à risco de mercado.

Para o tratamento do risco de mercado, foi apresentada uma proposta padronizada e uma proposta alternativa, mais sofisticada e baseada nos modelos internos utilizados pelas instituições.

O modelo padronizado baseou-se na proposta apresentada em 1993 pelo próprio comitê da Basiléia, propondo uma então nova ferramenta de administração de risco - o Value at Risk (Var). 
Baseado em uma distribuição de probabilidades do valor de mercado de uma carteira ao final de um período de negociação, essa medida de risco informava o pior cenário possível em relação à perda máxima provável dentro de um valor referência de probabilidade de ocorrência. No caso do novo Acordo essa probabilidade foi estipulada em $95 \%$ para dez dias.

De forma a não sufocar inovações em técnicas de gestão de risco, o Comitê de Basiléia permitiu aos bancos usarem sua própria medida interna de VAR para cálculo das exigências de capital. A permissão do uso da abordagem interna era vinculada a prévia aprovação pelos reguladores. "Tal aprovação seria rápida se o banco puder provar que tem uma função independente de gestão de risco e que usa uma medida sólida capaz de sustentar um VAR de 99\% para 10 dias [...]." (GUTTMAN, 2006, p.189).

\section{Risco operacional}

A exigência de capital mínimo direcionado à riscos operacionais é novidade em relação ao primeiro Acordo. Segundo o Comitê, a definição desse tipo de risco é que "risco operacional é definido como o risco de perda resultante de processos internos, pessoas e sistemas inadequados ou falhos, ou de eventos externos." (BCBS, 2004, p.140).

Eventos externos, como uma catástrofe mundial como, por exemplo, o atentado às torres gêmeas do World Trade Center em Nova York em 2001, ou os terríveis tsunamis, furacões, e demais catástrofes naturais com alto potencial de destruição de cidades - e conseqüentemente de operações dos bancos - são exemplos de riscos operacionais com remotas possibilidades de previsibilidade, mas enorme potencial de danos nos balanços. "Enquanto o risco de crédito e o risco de mercado são ambos aceitos voluntariamente na busca por maiores retornos e seguem padrões recorrentes, o risco operacional ocorre além do controle do escalão administrativo superior de um banco.” (GUTTMAN, 2006, p.192).

O capital para risco operacional pode ser calculado seguindo três distintas abordagens, sendo elas: indicador básico (Basic Indicator Approach), abordagem padronizada e mensuração avançada (Advanced Measurement Approaches, AMA). 
Pelo método básico (Basic Indicator Approach) o capital requerido para risco operacional é calculado multiplicando-se a média da receita bruta dos últimos três anos de resultado positivo por um fator de $15 \%$.

A abordagem padronizada também é baseada na receita bruta dos últimos três anos, mas o índice multiplicador varia entre $12 \%$ e $18 \%$, conforme as diferentes linhas de negócios do banco. Assim as atividades dos bancos são divididas em diferentes linhas de negócio, sendo aplicado um fator a cada tipo de operação, conforme detalhado no quadro 3.

\begin{tabular}{l|c} 
Linhas de Negócio & Fator Beta \\
\hline Mercado de Capitais & $18 \%$ \\
\hline Tesouraria & $18 \%$ \\
\hline Varejo & $12 \%$ \\
\hline Comercial & $15 \%$ \\
\hline Pagamentos e liquidações & $18 \%$ \\
\hline Serviços de agente & $15 \%$ \\
\hline Administração de ativos & $12 \%$ \\
\hline Corretagem de varejo & $12 \%$ \\
\hline
\end{tabular}

Quadro 3: Linhas de negócios - abordagem padronizada Fonte: BCBS, 2004.

Na mensuração avançada (Advanced Measurement Approaches, AMA), a própria mensuração interna de riscos operacionais dos bancos é utilizada para o cálculo das exigências de capital referentes à riscos de natureza operacional. A utilização desses sistemas internos de mensuração de risco operacional são sujeitas à autorização do órgão supervisor, e devem incluir critérios qualitativos e quantitativos (BCBS, 2004).

b. Pilar 2 - Revisão Supervisória

A idéia supervisionaria contida no pilar 2 de Basiléia II parte do pressuposto que bancos que almejem lucro devem ser supervisionados pelo autoridade reguladora. $\mathrm{E}$ 
quanto maior o grau de liberdade do banco em seus negócios, mais intensa deve ser a supervisão.

Tal mentalidade possui uma lógica bastante plausível. É interessante dar liberdade a um banco para determinar o nível adequado de capital baseado em suas próprias avaliações de risco. No entanto este processo deve ser supervisionado de perto, evitando distorções e fraudes.

Dessa forma, aquelas instituições que optarem pelo método de classificação interna de risco de crédito (IRB) e/ou a abordagem avançada de mensuração de risco operacional (AMA) devem manter relacionamento próximo com as agências de supervisão de cada país.

Guttman (2006) ressalta a importância deste trabalho desenvolvido pelas agências, lembrando que cabe a tais entidades a possibilidade de exigir reservas adicionais de capital para situações marcadas pela instabilidade e flutuações decorrentes de momentos de deterioração iminente do desempenho macroeconômico da economia doméstica.

Assim, os reguladores bancários passam a ter liberdade de exigir capital adicional não apenas para os riscos previstos no Pilar I (risco de crédito, de mercado e operacional), mas também podem exigir capital extra para riscos não mensuráveis e desprovidos de homogeneidade, como risco de taxas de juros e riscos provenientes de eventuais efeitos dos ciclos de negócios.

Muito provavelmente, os supervisores exigirão mais capital bancário, além do mínimo regulamentado [...] Tal antecipação é crucial, a não ser que queiramos ser surpreendidos por falências inesperadas de bancos sub-capitalizados devido à perdas resultantes de recessão. (GUTTMAN, 2006, p.196, grifo meu).

E continua o autor, quase que prevendo a iminente crise financeira que solapou os mercados internacionais em 2008. 
Tendo desfrutado do luxo de condições muito favoráveis para a maior parte das atividades bancárias nos últimos cincos anos, pode ser que nem os bancos nem os seus supervisores percebam plenamente, neste momento, as conseqüências potencialmente destruidoras de grandes crises financeiras, como se mostrou de forma recorrente durante mais de duas décadas, entre 1973 e 1999. (GUTTMAN, 2006, p.196).

Os princípios essências do Pilar 2 de Basiléia 2 são:

- Princípio 1: Os bancos devem ter um processo próprio de avaliação de riscos para adequação do nível de capital corresponde ao seu nível de exposição;

- Princípio 2: A avaliação dos procedimentos internos dos bancos para avaliação de risco deve ser supervisionado pela autoridade competente, cabendo a ela a exigência de ações corretivas caso haja falhas no processo;

- Princípio 3: Os supervisores devem possuir a expectativa que haja capital excedente em relação aos índices regulatórios mínimos;

- Princípio 4: A necessidade dos supervisores intervirem caso o nível de capital fique abaixo do mínimo exigido;

Essa relação de vigilância apontada nos princípios que regem a revisão supervisória permite garantir uma maior aderência do Acordo, além de garantir que todos os riscos materiais enfrentados pelos bancos sejam tratados no processo de avaliação de capital.

O Pilar 2 prescreve uma avaliação abrangente de riscos da maneira seguinte: Todos os riscos materiais enfrentados pelo banco devem ser tratados no processo de avaliação de capital. Ainda que o Comitê reconheça que nem todos os riscos podem ser precisamente mensurados, deve-se desenvolver um procedimento de estimativas de riscos [...] (CORNFORD, 2006, p.69). 
c. Pilar 3 - Disciplina de Mercado (Transparência)

O Pilar 3 tem o objetivo de complementar as abordagens de requerimentos mínimos de capital e supervisão bancária, representando um meio adicional para dar maior solidez ao mercado financeiro. Para isso o Pilar 3 busca gerar maior transparência nas operações, disciplinando os mercados a operarem com um nível de gestão de riscos mais apurado.

Segundo Guttman (2006), essa disciplina surge da punição dos bancos pelos investidores que julgarem que uma instituição gerencie inadequadamente o risco inerente de suas carteiras. Esse impacto punitivo do mercado afetaria diretamente os custos de funding e cotações de ações, por exemplo.

Como forma de garantir a transparência esperada, Basiléia II especifica que tipo de informação deva ser disponibilizada, além de determinar o formato esperado para sua divulgação.

Essas exigências de divulgação de informação incluem informações gerais sobre questões estratégicas, como a forma de gestão do risco ou planos para capitalização das operações. As exigências englobam tanto informações qualitativas quanto quantitativas a respeito da adequação de capital dos diversos aspectos envolvendo risco tratados no Pilar 1 e Pilar 2.

Com tais medidas, o Comitê esperava prover o mercado com as condições necessárias para avaliar o comportamento e posicionamento das instituições sobre os aspectos relativos ao nível de risco das operações. Quanto mais avançada a abordagem de avaliação de riscos, maior o número de informações exigidas das instituições a respeito da estrutura de capital, adequação de capital, aplicação de capital, riscos e mitigação de riscos (CORNFORD, 2006).

"Dado seu escopo e sua profundidade, o Pilar 3 de Basiléia II é, sem dúvida, o mais ambicioso regime de divulgação de informações jamais aplicado a instituições financeiras." (GUTTMAN, 2006, p.203). 


\section{REGULAÇÃo BANCÁRIA PARA CONTROLE DE RISCO NO BRASIL}

\subsection{O Acordo da Basiléia I, os Regulamentos Domésticos e os Controles Internos}

A fragilidade da mensuração dos riscos das instituições financeiras no Brasil era fruto de um processo histórico, iniciado nas duas décadas anteriores a 1994, quando a existência de inflação demasiadamente alta permitia aos bancos obterem ganhos com passivos não remunerados, como os depósitos à vista. (PUGA, 2009). Tais ganhos encobriam e compensavam eventuais ineficiências operacionais, fragilizando a correta mensuração dos riscos inerentes às operações.

Segundo Mendonça (2006), em 1999 o Banco Mundial e o Fundo Monetário Internacional recomendaram ao Banco Central brasileiro a adoção de padrões de supervisão bancária contidos no documento Core Principles for Effective Banking Supervision, publicado em setembro de 1997 pelo BIS.

A Resolução 2.099, de 17 de agosto de 1994, marca o momento em que as recomendações estabelecidas pela Basiléia I são incorporadas no país. A resolução apresentou quatro anexos, detalhando as determinações a respeito do funcionamento e organização das instituições financeiras, exigindo limites mínimos de capital e patrimônio líquido para o funcionamento dos bancos, disciplinando a instalação e funcionamento das dependências das instituições financeiras autorizadas a operar no país e, finalmente, fixando novas regras de determinação do Patrimônio de Referência - PR (FORTUNA, 2004). Esse PR é o chamado capital regulatório.

Neste momento, como grande contribuição para o controle e gerenciamento do risco das instituições, o foco da abordagem de supervisão passa a não mais focar no patrimônio líquido das instituições como referência, mas estabelecem-se limites em função do nível de risco de crédito gerado pelas operações (ativos ponderados pelo risco). 
Basiléia I, por meio da padronização, trouxe condições de competitividade das instituições financeiras nacionais na esfera global. "A necessidade de patrimônio passa a ser baseada nos riscos assumidos pelas instituições ao emprestarem, em vez dos riscos incorridos, em função do que tomam emprestado." (GUIMARÃES, LIMA, 2010, p.215).

Nesse sentido, determina-se que as instituições financeiras com operações no país mantenham um nível mínimo de capital corresponde ao respectivo nível de risco de crédito de seus ativos. Os ativos passam a ser ponderados pelo risco, da seguinte forma: risco nulo apresenta fator de ponderação igual a $0 \%$. Risco reduzido é ponderado pelo fator de $20 \%$ ou $50 \%$, e risco normal ponderado pelo fator de 100\%. A Resolução 2.099 "aprimorou o conceito de risco de crédito." (ALVES, ALVEZ, 2010, p.175).

Inicialmente o cálculo do patrimônio líquido exigia a aplicação de um Fator de Risco F de 8\%, aplicável sobre o ativo ponderado pelo seu percentual de risco. O CMN, em 25 de junho de 1997, aumentou esta requisição para 10\%. Já a circular número 2.784, de 27 de novembro de 1997, ampliou esta requisição para 11\%, levando o Brasil a adotar assim uma postura mais conservadora do que a pregada por Basiléia I ( $8 \%)$.

As inúmeras mudanças introduzidas no Brasil a partir de agosto de 1994 marcam “[...] o início da adoção pelo Brasil das premissas subjacentes ao Acordo de Capital de 1988 [...] um marco regulatório em nível de regulação prudencial." (LIMA, 2005, p.201).

Puga (1999) ressalta que a implantação de medidas mais ambiciosas para reestruturar o sistema financeiro, no entanto, foi adiada para o segundo ano do Plano Real. A diminuição do ritmo de crescimento econômico em 1995, um período marcado pela adoção de políticas restritivas, notadamente na política monetária e creditícia devido a crise mexicana, disparou uma crise que culminou com a liquidação do Banco Econômico, em agosto de 1995. Nesse momento era inevitável a necessidade de ação por parte das autoridades.

Em 1995, baseado na idéia de que a prevenção por parte das autoridades gera um custo social muito menor do que os regimes especiais de intervenção, liquidação e 
administração temporária (ALVES, ALVEZ, 2010; LIMA, 2005), é criado o Programa de Estímulo à Reestruturação e ao Fortalecimento do Sistema Financeiro Nacional (PROER) e o Programa de Incentivo à Redução da Presença do Setor Público Estatal na Atividade Financeira Bancária e a Privatização de Instituições Financeiras Estaduais (PROES). O PROER foi instituído pelo Conselho Monetário Nacional (CMN) em 03 de novembro de 1995, por meio da Resolução número 2.208 e da Medida Provisória (MP) número 1.179, posteriormente convertida na Lei número 9.710/98.

Ainda no ano de 1995, mais precisamente em 31 de agosto de 1995, também é criado o Fundo Garantidor de Crédito (FGC), por meio da Resolução CMN número 2.211/95.

Com estes programas, o governo gerou formas de o BC monitor o Sistema Financeiro Nacional, permitindo que atuassem no país apenas aquelas instituições que apresentassem uma operação saudável em termos de solidez financeira.

"Nesse contexto, cabe lembrar que até 1995 o BC não dispunha de meios legais para ação preventiva junto ao Sistema Financeiro Nacional, com vistas à recuperação de instituições financeiras." (ALVES, ALVEZ, 2010, p.174). Este cenário jurídico é modificado com a Medida Provisória número 1.182 de 17 de novembro de 1995 (posteriormente convertida na Lei número 9.447, de 14 de março de 1997), dotando a autarquia de poderes regulatórios e capacitando-o legalmente com a possibilidade de atuação reguladora e saneadora do Sistema Financeiro Nacional.

Assim, este é um período marcado pelo incremento do poder do $\mathrm{BC}$ no que se refere à atividade de regulador e guardião do SFN.

Quando a economia passa por um grande reordenamento, como que ocorreu no Brasil após a implantação do Plano Real, a atividade bancária, se não sofrer o necessário processo de ajuste estrutural, fica exposta a um crescente risco sistêmico. Na ausência desse ajuste, as soluções [...] normalmente baseadas em regimes especiais de intervenção, liquidação e administração especial temporária, tem um custo social mais elevado do que a ação prévia das autoridades. (LIMA, 2005, p.203). 
A evolução do mercado e dos instrumentos financeiros motivou inúmeros aprimoramentos nas determinações proferidas em 1994. Entre elas destacam-se as resoluções CMN número 2.283/96, facultando o uso do conceito de conglomerado para o cálculo de alguns limites operacionais e a 2.486/98 (Chinese Wall), tornando obrigatória e segregação das operações de gestão de capital de terceiros das demais atividades.

Alves e Alvez (2010) ressaltam, como grande contribuição para a prevenção do risco de crédito, a criação em 1997 da Central de Risco de Crédito (Atual Sistema de Informações de Crédito), por meio da resolução CMN número 2.390/97. Na Central constaria o nome de todos os tomadores de crédito em valor igual ou superior à $\mathrm{R} \$ 50.000$; valor reduzido gradativamente até chegar à $\mathrm{R} \$ 5.000$. Esse sistema, aplicado tanto à pessoas físicas quanto à pessoas jurídicas, fornecia informações sobre o montante de crédito na economia e o perfil de risco de cada cliente.

Ainda visando a redução de riscos de crédito, a Resolução número 2.493, de maio de 1998, permitiu aos bancos venderem parte ou a totalidade das carteiras de créditos - inclusive aqueles em atraso e em liquidação - em seu poder para sociedades anônimas de objeto exclusivo, por meio das então denominadas companhias securitizadoras de crédito financeiro.

Em 1999 o BC publicou a Resolução número 2.543/99, introduzindo o conceito de Patrimônio Líquido Ajustado (PLA).

A implantação de controles internos - historicamente destinados para redução de fraudes - foi outro movimento internacional que causou grande impacto na formulação das políticas prudenciais. Janeiro de 1998 marca a data da divulgação, pelo comitê da Basiléia, do documento contendo "Principles for the Assessment of Internal Control Systems", desenhado de forma a ampliar o escopo das políticas de controles internos. O documento incorporou vários riscos com os quais se deparam as instituições financeiras, tais como risco de crédito, de mercado, operacional, legal, de reputação, etc. (ALVES, ALVEZ, 2010).

$\mathrm{Na}$ esteira do documento - de forma a tratar sobre o risco operacional - o CMN elaborou o sistema de controles interno brasileiro (Resolução CMN número 
2.554/98, de 24 de setembro de 1998), obrigando as instituições financeiras a apresentarem ao Banco Central um programa para implantação de sistemas de controles internos, atuando assim sobre o risco operacional das instituições. Dessa forma, o BC reforçava a postura ativa de controles adotada pelo Banco Central após a introdução do Plano Real. A exigibilidade de maior transparência das operações é o grande destaque exigido pelas novas normas. Entre as disposições basiliares propostas, destacam-se:

- Criação de canais de comunicação interna;

- Implementação de acompanhamento sistemático do cumprimento das normais legais e regulamentares;

- Determinação de inclusão da auditoria interna no ambiente de controles internos;

- Imposição de controles operacionais mais restritivos para instituições que não cumprissem as determinações propostas;

É indispensável enfatizar a respeito dessa norma que, ao lado do interesse do BC de supervisionar os integrantes do segmento financeiro, deve estar o interesse dos controladores e da administração de cada instituição em manter a higidez do sistema. (ALVES, ALVEZ, 2010, p.177).

Além de limites adicionais exigidos para diferentes níveis de risco dos ativos, também foi estabelecido limites mínimos de capital para a constituição de um banco. Para constituição de um banco comercial passou-se a exigir R \$7 milhões de capital realizado e patrimônio líquido. Já para os bancos de investimento a exigência mínima era de $\mathrm{R} \$ 6$ milhões, e de $\mathrm{R} \$ 3$ milhões para as financeiras.

O tratamento do risco de crédito também foi alvo de ampla revisão nos anos seguintes. A edição das Resoluções CMN 2.682/99, de 21 de dezembro de 1999, e 2.697/00, de 24 de fevereiro de 2000, trouxeram proposições mais flexíveis, aliadas a um forte conceito prudencial sobre a classificação do risco de crédito de qualquer tipo de operação bancária. 
Tais Resoluções também trataram do provisionamento de valores nos balanços das instituições financeiras em função das diferentes faixas de risco. Essas resoluções foram baseadas em dois documentos internacionais que serviram de referência para o aprimoramento dos critérios de classificação de crédito no Brasil: "Os princípios da OCDE sobre o Governo das Sociedades" - documento internacional da OCDE publicado em 1999 e revisado em 2004 como forma a aprimorar as regras sobre governanças - e "Enhancing corporate governance for banking organizations" também publicado pelo BIS originalmente em 1999 e revisado em 2006 (ALVES, ALVEZ, 2010).

Por meio destas Resoluções, a partir de março de 2000, os bancos foram obrigados a classificar o risco de seus empréstimos considerando critérios mais amplos e conservadores do que os praticados até então. Dessa forma foi criada uma escala com nove níveis de risco, variando de AA (não exigibilidade de provisão) até $\mathrm{H}$ (exigência de $100 \%$ de provisão), conforme detalhado no quadro 4.

\begin{tabular}{ccc} 
Nível & Provisão Mínima & Atraso (dias) \\
\hline AA & & \\
A & $0,5 \%$ & \\
B & $1 \%$ & 15 a 30 \\
C & $3 \%$ & 31 a 60 \\
D & $10 \%$ & 61 a 90 \\
E & $30 \%$ & 91 a 120 \\
F & $50 \%$ & 121 a 150 \\
G & $70 \%$ & 151 a 180 \\
H & $100 \%$ & Acima de 180
\end{tabular}

Quadro 4: Níveis de risco da Resolução 2.682 Fonte: Resolução 2.682.

Na visão de Guimarães e Lima (2010) há ainda um segundo fator relevante que permitiu o incremento da solidez do modelo brasileiro de gerenciamento de risco de crédito: A Resolução número 2.844/01, que limitou a exposição por cliente em $25 \%$ do Patrimônio de Referência da Instituição Financeira.

Também com viés prudencial, a Resolução número 2.692/99 definia critérios para a apuração do Patrimônio Líquido Exigido (PLE) e para cobertura de risco inerente a 
variação das taxas de juros. A Resolução CMN número 2.891/01 incrementou as proposições da Resolução número 2.692/99, fixando limites operacionais e incluindo exigências de capital para exposição cambial nas operações realizadas no mercado financeiro.

No sentido de dar maior aderência a boas práticas internacionais, houve a edição das Resoluções 3.040/02 e 3.041/02, posteriormente aprimoradas pela Resolução CMN número 3.141/03. Salienta-se nesse sentido o aperfeiçoamento das regras que regem e autorizam o funcionamento de instituições financeiras no Sistema Financeiro Nacional.

Ainda tratando sobre o detalhamento dos pré requisitos para operação de instituições financeiras, a Resolução CMN número 3.040/02 exigiu, entre outros pré requisitos, a elaboração de estudos de viabilidade econômica, dando mais elementos para o BC realizar uma avaliação qualitativa das instituições atuantes na esfera nacional (ALVES, ALVEZ, 2010).

\subsection{Comitê de Basiléia II no Brasil}

Dado que o novo Acordo da Basiléia propõe a substituição do critério de padronização, dando ênfase a um enfoque mais flexibilizado capaz de ajustar adequação de capital à exposição de risco da instituição, alguns pontos propostos até então foram revistos.

O objetivo da Basiléia II no Brasil segue os preceitos internacionais, adequando o nível de capital regulamentar ao nível de risco associado às operações conduzidas pelas instituições financeiras.

A forma como as novas regras da Basiléia - "adaptadas às condições, às peculiaridades e ao estágio de desenvolvimento do mercado brasileiro" - deveriam ser implementadas foi anunciada pelo Banco Central do Brasil em 8 de dezembro de 2004, por meio do Comunicado número 12.746. 
O Comunicado priorizou as determinações específicas para o capital de risco destinado ao Pilar I. Os principais pontos do comunicado estão sucintamente apresentados a seguir:

\section{Pilar 1}

- Risco de Crédito: No Brasil não será adotada a abordagem padronizada de Basiléia II, baseada em ratings divulgados pelas agências externas de classificação de risco de crédito. Será aplicado, para a maioria das instituições financeiras, abordagem padrão simplificada (APS). O Comunicado no entanto afirma que a utilização de abordagem avançada - baseada nos sistemas internos de classificação de risco - será permitida para instituições de grande porte, atuação internacional e relevância no SFN.

- Risco Operacional: O comunicado apenas informou que estudos e teste ainda estavam sendo realizados. Porém já indicava a expectativa de que as instituições elegíveis à utilização da abordagem avançada, com base em sistema interno de classificação de risco de crédito, se tornassem elegíveis à utilização de abordagens avançadas de mensuração do risco operacional.

- Risco de mercado: Expansão das recomendações contidas na emenda ao Acordo de Basiléia de 1988, publicada em 1996, permitindo o uso de modelos internos para as instituições que cumprirem os critérios de elegibilidade a serem divulgados.

\section{Pilares 2 e 3}

- O cronograma de implantação das novas medidas prioriza o pilar 1, mas exigia que, a cada etapa, existissem "ações equivalentes" no âmbito do pilar 2 (Processos de Supervisão) e pilar 3 (Transparência e Disciplina de Mercado).

Segundo o comunicado, as medidas deveriam ser adotadas de forma gradual, no período entre 2005 e 2011, englobando cinco etapas.

Esse processo de revisão, iniciado em 2004, levou à edição da Resolução CMN número 3.490, de 29 de agosto de 2007, determinando que cálculo do "Patrimônio de Referência Exigido" (PRE) das instituições financeiras seja composto por parcelas de risco de crédito, mercado e operacional. A Resolução entrou em vigor na data de sua publicação, produzindo efeitos a partir de $1^{\circ}$ de julho de 2008 , 
momento programado para revogação das Resoluções número 2.692/99 e CMN número 2.891/01, e fim do período de adaptação dos Bancos às novas regras. O dia $1^{\circ}$ de julho de 2008 é considerada o marco da implementação de Basiléia II no Brasil.

Em 27 de setembro de 2007, por meio do Comunicado número 16.137, o Banco Central ajustou o cronograma, apontando a nova programação para autorização do uso dos modelos de classificação interna de risco para provisionamento de capital para risco de crédito, operacional e de mercado. Dentre os principais pontos apontados no Comunicado número 16.137, destaca-se os seguintes pontos referentes ao pilar 1:

\begin{tabular}{|c|c|c|c|}
\hline & \multicolumn{3}{|l|}{ Pilar I } \\
\hline Prazos & Risco de Crédito & Risco de Mercado & Risco Operacional \\
\hline Até final de 2007 & & & $\begin{array}{l}\text { Há a previsão de } \\
\text { estabelecimento de } \\
\text { parcela de } \\
\text { requerimento } \\
\text { de capital para este } \\
\text { risco específico }\end{array}$ \\
\hline Até final de 2008 & implementação de estrutura para gerenciamento do risco de crédito & & \\
\hline Até final de 2009 & & \begin{tabular}{|lr} 
Início & do \\
processo & de \\
autorização & para \\
uso de & modelos \\
internos & para \\
apuração & do \\
requerimento & de \\
capital para & risco \\
de mercado & \\
\end{tabular} & \\
\hline Até final de 2010 & $\begin{array}{l}\text { Início do processo de autorização para uso da abordagem } \\
\text { básica baseada em classificações internas para apuração de requerimento } \\
\text { de capital para risco de crédito }\end{array}$ & & \\
\hline Até final de 2011 & $\begin{array}{l}\text { Início do processo de autorização para uso da abordagem avançada } \\
\text { baseada em classificações internas para apuração de } \\
\text { requerimento de capital para risco de crédito }\end{array}$ & & \\
\hline Até final de 2012 & & & $\begin{array}{l}\text { Início do processo } \\
\text { de autorização para } \\
\text { uso de modelos } \\
\text { internos } \\
\text { de apuração de } \\
\text { requerimento de } \\
\text { capital para risco } \\
\text { operacional }\end{array}$ \\
\hline
\end{tabular}

Quadro 5: Prazos de implementação de Basiléia II no Brasil, conforme comunicado 16.137 Fonte: elaborado pelo autor. 
Em relação aos pilares 2 e 3, apesar de as ações descritas no documento voltaremse primordialmente ao Pilar 1, "a cada uma corresponderão ações equivalentes no âmbito do Pilar 2 (Processos de Supervisão) e Pilar 3 (Transparência e Disciplina de Mercado)". 


\section{METODOLOGIA DO TRABALHO}

\subsection{O modelo de pesquisa}

O modelo de pesquisa procura investigar qual o impacto da regulação no risco dos bancos regulados.

Como a regulação pode ter distinto efeito sobre bancos de diferentes portes, a amostra total dos bancos listados na Bovespa na ocasião da regulação será dividida em dois subgrupos, seguindo o critério do tamanho do ativo total, compondo dois distintos grupos de análise conforme figura a seguir:

\begin{tabular}{|l|l|}
\hline & Critério \\
\hline Grupo 1 & $50 \%$ maiores bancos \\
\hline Grupo 2 & $50 \%$ menores bancos \\
\hline
\end{tabular}

Quadro 6: Definição dos grupos de análise Fonte: Elaborado pelo autor.

Consideraremos os seguintes eventos como foco da análise:

- Evento 1: Comunicado número 12.746, de 8 de dezembro de 2004, relevante marco na regulação prudencial no Brasil, que anunciou a forma como a nova estrutura de capital - Basiléia II - seria implantada no Brasil;

- Evento 2: Concordata do Banco Lehman Brothers, em 15 de setembro 2008, estopim da maior crise financeira desde 1929, e momento em que o acirramento da regulação de instituições financeiras passou a ser debatido;

Os testes estatísticos iniciais serão aplicados com o intuito de determinar se as amostras dos intervalos possuem distribuição normal. Para cada banco foi computada as medidas de risco ex ante e ex post, 24 meses antes e 24 meses depois do evento regulatório. Despreza-se ainda o período amostral referente aos dois meses imediatamente antecedentes e aos dois meses imediatamente posteriores ao evento analisado, conforme detalhado na figura 3. 


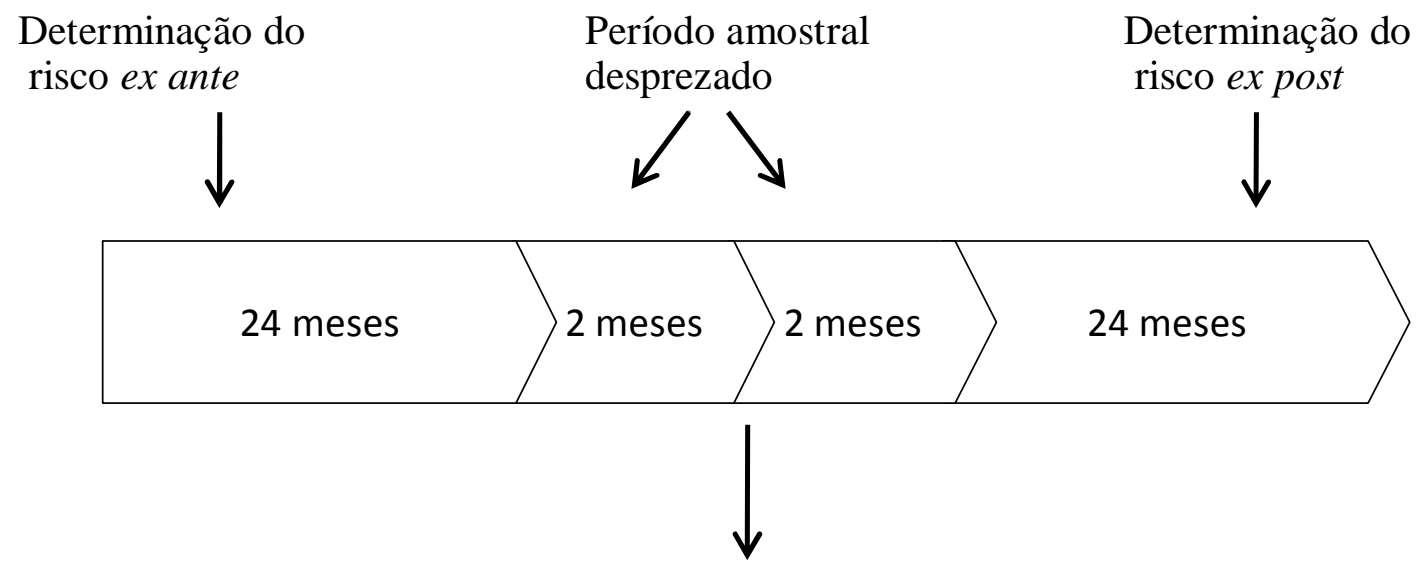

Evento regulatório analisado

Figura 3: Procedimento para determinação do risco

A variável de interesse e dependente neste estudo é o risco, medido pelo beta referente ao período amostral analisado. O beta de cada instituição será calculado utilizando-se a equação (2.21) deste estudo. Como carteira de mercado será utilizado o índice Bovespa (Ibovespa).

Para testar a normalidade da distribuição do retorno e beta ex ante e ex post dos dados, será utilizado o teste de normalidade Shapiro-Wilk. Segundo Maroco (2007 apud Fávero et al., 2009), este teste é mais apropriado do que o teste K-S (Kolmogorov-Smirnov) para situações de pequenas amostras $(n<30)$.

Confirmada a hipótese de normalidade dos dados, será aplicado sobre a amostra contendo a medida de risco ex ante e ex post de cada instituição financeira regulada o teste $\mathrm{T}$ de comparação de médias (paired samples $T$ test), avaliando assim a influência da regulação sobre o risco das instituições analisadas.

O problema de pesquisa será respondido pela aceitação ou rejeição da hipótese.

\subsection{Hipóteses formuladas}

Conforme já mencionado, o objetivo principal da pesquisa é investigar o impacto da regulação no risco dos bancos envolvidos. 
Dessa forma, as seguintes hipóteses nulas serão testadas:

$H_{0,1}=$ A regulação não altera o risco dos maiores bancos;

$H_{1,1}=$ A regulação altera o risco dos maiores bancos;

$H_{0,2}=$ A regulação não altera o risco dos menores bancos;

$H_{1,2}=$ A regulação altera o risco dos menores bancos.

\subsection{Coleta de Dados}

Os dados das variáveis de interesse utilizados são secundários, e estão disponíveis no banco de dados da Economatica, disponível no Laboratório de Pesquisas em Finanças (LPFin) da FEA-USP.

Serão selecionadas para compor o grupo analisado todos as instituições com ações listadas na Bolsa de Valores de São Paulo (Bovespa) na ocasião do evento regulatório observado e classificadas como "bancos" pela Bovespa.

Conforme detalhado anteriormente, as amostras foram dividas em dois grupos, sendo o critério o tamanho do ativo total. Assim, o primeiro grupo foi composto pelos $50 \%$ maiores bancos, e o segundo grupo pelos $50 \%$ menores bancos. O objetivo desta divisão é determinar se o tamanho da instituição financeira é determinante para a eficácia ou não da regulação.

Para definição do ranking dos bancos, foi considerado o valor do ativo total das instituições em dezembro de 2004 e dezembro de 2008, ano da divulgação do plano de implantação da Basiléia II no Brasil e da concordata do Banco Lehman Brothers, respectivamente.

Importante ressaltar que as instituições que apresentaram baixa liquidez das ações no período analisado foram retiradas da amostra. 


\section{ANÁLISE DOS RESULTADOS}

As tabelas 1 e 2 apresentam os bancos identificados segundo o critério descrito anteriormente e que compuseram a amostra deste estudo, para os anos de 2004 e 2008.

\begin{tabular}{|r|l|l|l|r|}
\hline Ranking & Instituição & $\begin{array}{l}\text { Tipo } \\
\text { de Ativo }\end{array}$ & Ticker & $\begin{array}{l}\text { Valor do Ativo Total } \\
\text { em dezembro/2004 } \\
\text { (milhares) }\end{array}$ \\
\hline 1 & Banco do Brasil & ON & BBAS3 & $239.014 .143,00$ \\
\hline 2 & Banco Bradesco & PN & BBDC4 & $184.926 .468,00$ \\
\hline 3 & Itau & PN & ITUB4 & $130.338 .643,00$ \\
\hline 4 & Unibanco & ON & UBBR3 & $79.349 .712,00$ \\
\hline 5 & Banespa & PN & BESP4 & $35.249 .607,00$ \\
\hline 6 & Banco do Nordeste do Brasil & ON & BNBR4 & $13.167 .413,00$ \\
\hline 7 & Banco Sudameris Brasil & ON & BFIT3 & $12.724 .942,00$ \\
\hline 8 & Banrisul & PNB & BRSR5 & $12.126 .168,00$ \\
\hline 9 & Banco Alfa de Investimento & PN & BRIV4 & $6.975 .326,00$ \\
\hline 10 & Banco Mercantil Brasil & ON & BMEB4 & $4.551 .035,00$ \\
\hline 11 & Banco da Amazonia & ON & BAZA3 & $3.833 .959,00$ \\
\hline 12 & Banco Estado Santa Catarina (BESC) & PNB & BSCT6 & $3.545 .633,00$ \\
\hline 13 & Banestes & ON & BEES3 & $2.778 .247,00$ \\
\hline 14 & Bonsorcio Alfa de Administração & PNF & BRGE12 & $2.001 .393,00$ \\
\hline 15 & Alfa Holdings & PNB & RPAD6 & $1.743 .431,00$ \\
\hline 16 & Banco do Estado de Sergipe (Banese) & PN & BGIP4 & $1.050 .103,00$ \\
\hline 17 & Banco do Estado do Piaui & ON & BPIA3 & $182.557,00$ \\
\hline 18 & Banco Mercantil de Investimentos & PN & BMIN4 & $41.351,00$ \\
\hline
\end{tabular}

Tabela 1 - Ranking das bancos em dezembro/2004 


\begin{tabular}{|c|c|c|c|c|}
\hline Ranking & Instituição & $\begin{array}{l}\text { Tipo } \\
\text { de Ativo }\end{array}$ & Ticker & $\begin{array}{l}\text { Valor do Ativo Total } \\
\text { em dezembro/2008 } \\
\text { (milhares) }\end{array}$ \\
\hline 1 & Itau & PN & ITUB4 & 632.728 .403 \\
\hline 2 & Banco do Brasil & ON & BBAS3 & 521.272 .817 \\
\hline 3 & Banco Bradesco & PN & BBDC4 & 454.413.043 \\
\hline 4 & Banco Santander Brasil & UNT N2 & SANB4 & 340.635 .472 \\
\hline 5 & Banco Nossa Caixa & ON & BNCA3 & 54.272 .860 \\
\hline 6 & Banrisul & PNB & BRSR5 & 25.205 .375 \\
\hline 7 & Banco do Nordeste do Brasil & ON & BNBR4 & 16.177.235 \\
\hline 8 & Banco Alfa de Investimento & PN & BRIV4 & 12.275 .955 \\
\hline 9 & Banestes & ON & BEES3 & 8.524 .501 \\
\hline 10 & \begin{tabular}{|l|} 
Banco da Amazonia \\
\end{tabular} & ON & BAZA3 & 7.239 .780 \\
\hline 11 & \begin{tabular}{|l|} 
Banco Mercantil Brasil \\
\end{tabular} & ON & BMEB4 & 6.793 .208 \\
\hline 12 & Consórcio Alfa de Administracao & PNF & BRGE12 & 4.993 .600 \\
\hline 13 & \begin{tabular}{|l|} 
Alfa Holdings \\
\end{tabular} & PNB & RPAD6 & 2.939 .095 \\
\hline 14 & Banco do Estado de Sergipe (Banese) & PN & BGIP4 & 2.150 .383 \\
\hline 15 & Banco Mercantil de Investimentos & $\mathrm{PN}$ & BMIN4 & 1.215 .397 \\
\hline
\end{tabular}

Tabela 2 - Ranking das bancos em dezembro/2008

As tabelas 3 e 4 apresentam o retorno acionário semanal médio e o beta dos retornos dos bancos selecionados na amostra analisada, para o ano de 2004 e 2008, respectivamente .

\begin{tabular}{|c|c|c|c|c|c|c|c|}
\hline \multirow[b]{2}{*}{ Ranking } & \multirow[b]{2}{*}{ Instituição } & \multirow[b]{2}{*}{$\begin{array}{l}\text { Tipo } \\
\text { de Ativo }\end{array}$} & \multicolumn{2}{|c|}{ Antes do Evento } & \multicolumn{2}{|c|}{ Após o Evento } & \\
\hline & & & \begin{tabular}{|l|} 
Retorno \\
Médio
\end{tabular} & Beta & \begin{tabular}{|l|} 
Retorno \\
Médio
\end{tabular} & Beta & \\
\hline 1 & Banco do Brasil & ON & $1,3 \%$ & 0,96 & $0,8 \%$ & 0,88 & \multirow{9}{*}{ 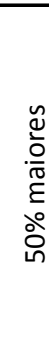 } \\
\hline 2 & Banco Bradesco & $\mathrm{PN}$ & $0,8 \%$ & 0,89 & $0,9 \%$ & 1,00 & \\
\hline 3 & Itau & $\mathrm{PN}$ & $1,1 \%$ & 0,90 & $0,6 \%$ & 0,99 & \\
\hline 4 & Unibanco & ON & $-0,1 \%$ & 0,32 & $1,0 \%$ & 0,26 & \\
\hline 5 & Banespa & PN & $1,2 \%$ & 0,40 & $0,2 \%$ & 0,34 & \\
\hline 6 & Banco do Nordeste do Brasil & ON & $1,1 \%$ & 0,02 & $1,9 \%$ & 0,84 & \\
\hline 7 & Banco Sudameris Brasil & ON & $0,8 \%$ & 0,19 & $0,6 \%$ & 0,58 & \\
\hline 8 & Banrisul & PNB & $1,7 \%$ & $-0,08$ & $1,4 \%$ & 0,30 & \\
\hline 9 & Banco Alfa de Investimento & PN & $0,0 \%$ & 0,11 & $0,3 \%$ & 0,02 & \\
\hline 10 & Banco Mercantil Brasil & ON & $1,0 \%$ & 0,19 & $0,3 \%$ & 0,08 & \multirow{9}{*}{ 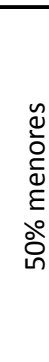 } \\
\hline 11 & Banco da Amazonia & ON & $0,8 \%$ & 0,37 & $0,4 \%$ & 0,57 & \\
\hline 12 & Banco Estado Santa Catarina (BESC) & PNB & $0,0 \%$ & 0,35 & $0,9 \%$ & 0,26 & \\
\hline 13 & Banestes & $\mathrm{ON}$ & $1,1 \%$ & 0,67 & $2,0 \%$ & 0,26 & \\
\hline 14 & Consorcio Alfa de Administração & PNF & $0,5 \%$ & 0,00 & $-0,1 \%$ & 0,00 & \\
\hline 15 & Alfa Holdings & PNB & $0,1 \%$ & 0,03 & $0,2 \%$ & $-0,17$ & \\
\hline 16 & Banco do Estado de Sergipe (Banese) & $\mathrm{PN}$ & $1,1 \%$ & 0,25 & $1,6 \%$ & 0,24 & \\
\hline 17 & Banco do Estado do Piaui & ON & $5,6 \%$ & $-1,36$ & $8,5 \%$ & 3,15 & \\
\hline 18 & Banco Mercantil de Investimentos & PN & $0,1 \%$ & $-0,38$ & $1,6 \%$ & 0,28 & \\
\hline
\end{tabular}

Tabela 3- Retorno Acionário Semanal Médio e beta dos bancos (período de 24 meses anterior e posterior ao comunicado n. 12.746, de 8 de dezembro de 2004) 


\begin{tabular}{|c|c|c|c|c|c|c|c|}
\hline \multirow[b]{2}{*}{ Ranking } & \multirow[b]{2}{*}{ Instituição } & \multirow[b]{2}{*}{\begin{tabular}{|l|} 
Tipo \\
de Ativo \\
\end{tabular}} & \multicolumn{2}{|c|}{ Antes do Evento } & \multicolumn{2}{|c|}{ Após o Evento } & \\
\hline & & & \begin{tabular}{l|} 
Retorno \\
Médio
\end{tabular} & Beta & \begin{tabular}{|l|} 
Retorno \\
Médio
\end{tabular} & Beta & \\
\hline 1 & Itau & PN & $0,4 \%$ & 1,14 & $0,5 \%$ & 1,31 & \\
\hline 2 & Banco do Brasil & ON & $0,5 \%$ & 1,01 & $0,5 \%$ & 1,12 & \\
\hline 3 & Banco Bradesco & PN & $0,5 \%$ & 1,07 & $0,3 \%$ & 1,22 & 凹 \\
\hline 4 & Banco Santander Brasil & UNT N2 & $2,4 \%$ & 1,03 & $0,6 \%$ & 0,82 & $\cdot \frac{0}{\pi}$ \\
\hline 5 & Banco Nossa Caixa & ON & $-0,5 \%$ & 0,67 & $1,1 \%$ & 0,51 & $\frac{\varepsilon}{\circ}$ \\
\hline 6 & Banrisul & PNB & $1,1 \%$ & 0,71 & $1,4 \%$ & 0,17 & О्रे \\
\hline 7 & Banco do Nordeste do Brasil & ON & $1,5 \%$ & 1,12 & $0,3 \%$ & 0,47 & \\
\hline 8 & Banco Alfa de Investimento & PN & $0,3 \%$ & 0,55 & $0,0 \%$ & 0,19 & \\
\hline 9 & Banestes & ON & $1,3 \%$ & 0,79 & $0,3 \%$ & 0,77 & \\
\hline 10 & Banco da Amazonia & ON & $1,2 \%$ & 1,17 & $0,4 \%$ & 0,85 & y \\
\hline 11 & Banco Mercantil Brasil & ON & $1,2 \%$ & 0,19 & $0,2 \%$ & 0,15 & ”ั \\
\hline 12 & Consórcio Alfa de Administracao & PNF & $0,5 \%$ & 0,11 & $0,1 \%$ & 0,00 & $\stackrel{\bar{\Xi}}{\varepsilon}$ \\
\hline 13 & Alfa Holdings & PNB & $0,8 \%$ & $-0,40$ & $0,3 \%$ & 0,09 & वे \\
\hline 14 & Banco do Estado de Sergipe (Banese) & $\mathrm{PN}$ & $0,0 \%$ & 0,52 & $0,6 \%$ & 0,48 & 윤 \\
\hline 15 & Banco Mercantil de Investimentos & PN & $1,0 \%$ & 1,05 & $0,7 \%$ & 0,90 & \\
\hline
\end{tabular}

Tabela 4- Retorno Acionário Semanal Médio e beta dos bancos (período de 24 meses anterior e posterior à concordata do Banco Lehman Brothers, em 15 de setembro 2008)

Assim, por meio do teste de normalidade Shapiro-Wilk, verificou-se na tabela 5 que, para um nível de significância de 5\%, não é possível aceitar a hipótese nula de normalidade da distribuição do retorno ex ante e ex post relativo ao evento 1, ou seja, data de divulgação do comunicado número 12.746 de 8 de dezembro de 2004.

\begin{tabular}{|l|r|r|r|r|}
\hline \multirow{2}{*}{} & \multicolumn{2}{|c|}{$\mathbf{5 0 \%}$ maiores bancos } & \multicolumn{2}{c|}{$\mathbf{5 0 \%}$ menores bancos } \\
\cline { 2 - 5 } & Estatística & \multicolumn{1}{l|}{ Sig. } & Estatística & \multicolumn{1}{l}{ Sig. } \\
\hline Retorno ex ante & 0,905 & 0,284 & 0,626 & 0,000 \\
\hline Retorno ex post & 0,933 & 0,513 & 0,642 & 0,000 \\
\hline Beta ex ante & 0,874 & 0,136 & 0,834 & 0,050 \\
\hline Beta ex post & 0,904 & 0,275 & 0,586 & 0,000 \\
\hline
\end{tabular}

Tabela 5- Teste de normalidade das distribuições para evento 1 (Shapiro-Wilk)

Analisando o gráfico Q-Q Normal do retorno ex ante e ex post, gráfico gerado no software SPSS, verificou-se a existência de um ponto extremo, que se refere ao banco do Estado do Piauí. Este valor extremo foi então retirado da amostra.

Conduziu-se novamente o teste de normalidade K-S sobre as variáveis analisadas, e os resultados estão listados na tabela 6 . 


\begin{tabular}{|l|r|r|r|r|}
\hline \multirow{2}{*}{} & \multicolumn{2}{|c|}{$\mathbf{5 0 \%}$ maiores bancos } & \multicolumn{2}{c|}{$\mathbf{5 0 \%}$ menores bancos } \\
\cline { 2 - 5 } & Estatística & Sig. & Estatística & Sig. \\
\hline Retorno ex ante & 0,905 & 0,284 & 0,893 & 0,248 \\
\hline Retorno ex post & 0,933 & 0,513 & 0,900 & 0,287 \\
\hline Beta ex ante & 0,874 & 0,136 & 0,970 & 0,900 \\
\hline Beta ex post & 0,904 & 0,275 & 0,944 & 0,651 \\
\hline
\end{tabular}

Tabela 6 - Teste de normalidade das distribuições para evento 1, excluindo banco do Estado do Piauí (Shapiro-Wilk)

Como é possível notar, com a retirada do ponto extremo mencionado, o retorno e o beta ex ante e ex post apresentam distribuição normal.

Para a análise da normalidade da distribuição referente ao evento 2, ou seja, a concordata do Banco Lehman Brothers em 15 de setembro 2008, observou-se que para um nível de significância de 5\%, é possível aceitar a hipótese nula de normalidade na distribuição do retorno e beta ex ante e ex post para os dois grupos de análise.

\begin{tabular}{|l|r|r|r|r|}
\hline \multirow{2}{*}{} & \multicolumn{2}{|c|}{$\mathbf{5 0 \%}$ maiores bancos } & \multicolumn{2}{c|}{$\mathbf{5 0 \%}$ menores bancos } \\
\cline { 2 - 5 } & Estatística & Sig. & Estatística & \multicolumn{1}{l|}{ Sig. } \\
\hline Retorno ex ante & 0,9620 & 0,8390 & 0,9040 & 0,3150 \\
\hline Retorno ex post & 0,8220 & 0,0660 & 0,9710 & 0,9060 \\
\hline Beta ex ante & 0,7930 & 0,0350 & 0,9670 & 0,8700 \\
\hline Beta ex post & 0,9300 & 0,5480 & 0,8730 & 0,1610 \\
\hline
\end{tabular}

Tabela 7- Teste de normalidade das distribuições para evento 2 (Shapiro-Wilk)

Os resultados do teste $\mathrm{T}$ a seguir indicam que, para um nível de significância de $5 \%$, a hipótese nula de igualdade de médias no caso do beta não pode ser rejeitada para a amostra formada pelos $50 \%$ maiores bancos em ativo total. Os resultados são válidos tanto para o evento 1 quanto para o evento 2 , indicando que o beta ex ante e ex post não parecem ser estatisticamente diferentes.

Mesma situação ocorre com os resultados referentes ao grupo composto pelos $50 \%$ menores bancos em ativo total, tanto para o evento 1 quanto para o evento 2 . Em ambos os casos, não é possível rejeitar a hipótese nula. 


\begin{tabular}{|c|c|c|c|c|c|c|c|c|c|c|}
\hline & & \multirow{3}{*}{$\begin{array}{c}\text { Grupo } \\
\text { de análise }\end{array}$} & \multicolumn{5}{|c|}{ Diferenças emparelhadas } & \multirow[b]{3}{*}{$\mathbf{t}$} & \multirow[b]{3}{*}{ df } & \multirow{3}{*}{$\begin{array}{c}\text { sig. } \\
\text { (2-tailed) }\end{array}$} \\
\hline & & & \multirow[b]{2}{*}{ Média } & \multirow{2}{*}{\begin{tabular}{l|} 
Desvio \\
padrão
\end{tabular}} & \multirow{2}{*}{\begin{tabular}{|c|}
$\begin{array}{c}\text { Erro padrão } \\
\text { médio }\end{array}$ \\
\cline { 2 - 2 }
\end{tabular}} & \multicolumn{2}{|c|}{ Intervalo } & & & \\
\hline & & & & & & Inferior & Superior & & & \\
\hline \multirow{4}{*}{$\begin{array}{l}\text { Beta ex ante e } \\
\text { ex post }\end{array}$} & \multirow[b]{2}{*}{ Evento 1} & $50 \%$ maiores & $-0,16800$ & 0,30833 & \begin{tabular}{|r|}
0,10278 \\
\end{tabular} & $-0,40501$ & 0,06900 & $-1,635$ & 8 & 0,141 \\
\hline & & $50 \%$ menores & $-0,00392$ & 0,31817 & 0,11249 & $-0,26992$ & 0,26208 & $-0,35$ & 7 & 0,973 \\
\hline & \multirow[b]{2}{*}{ Evento 2} & $50 \%$ maiores & 0,16227 & 0,33278 & 0,12578 & $-0,14550$ & 0,47004 & 1,290 & 6 & 0,244 \\
\hline & & $50 \%$ menores & 0,06771 & 0,25861 & 0,09143 & $-0,14850$ & 0,28391 & 0,741 & 7 & 0,483 \\
\hline
\end{tabular}

Tabela 8 - Teste T de comparação de médias para amostras emparelhadas: análise do desvio padrão anterior e posterior ao evento regulatório

Os resultados sugerem que o efeito do evento regulatório sobre o risco dos bancos não impactou, de forma estatisticamente significante, os bancos atuantes no Brasil. O resultado é estatisticamente significante tanto para as $50 \%$ maiores bancos em ativo total quanto para as $50 \%$ menores instituições em ativo total.

Dessa forma, a partir das análises do comportamento do beta dos bancos listados na Bovespa durante o período analisado, é possível verificar que eventos regulatórios relevantes não surtiram efeito no que diz respeito à redução do risco dos bancos atuantes no mercado brasileiro. 


\section{CONSIDERAÇÕES FINAIS}

Momentos de euforia no mercado financeiro geram o distanciamento entre o preço de um ativo e seu valor fundamental. Não foi diferente com a recente crise financeira de 2008, quando o mundo viu a formação de uma bolha nos preços dos imóveis americanos. Seu financiamento - a custa de juros baixos - permitiu a criação de carteiras de crédito teoricamente adequadas para a securitização dos recebíveis. Apenas a ponta do iceberg de uma das maiores crises financeiras da história.

Ainda que a economia brasileira e o sistema financeiro nacional tenham superado a recente crise financeira de forma - comparativamente a outros países - positiva, cabe extrair lições do episódio, permitindo o aumento da resiliência do país diante de eventuais futuras crises. Para isso, é crucial o entendimento do impacto de ações desenvolvidas nos anos que antecederam a crise.

Assim, o objetivo principal deste trabalho foi o de investigar se os eventos regulatórios selecionados alteraram o risco dos bancos de capital aberto e listados na Bolsa de Valores de São Paulo.

Inicialmente foi realizada uma pesquisa bibliográfica apresentando o conceito de risco sob a ótica da moderna teoria de finanças. Destacam-se a Teoria de Seleção de Carteiras, proposta por Markowitz (1952), e a Teoria de Precificação de Ativos (CAPM), proposta por Sharpe (1964). Tais estudos englobam o conceito de precificação de ativos refletindo todo tipo de informação disponível de forma a igualar preço a fundamentos. Este conceito de preço justo está por trás da hipótese de mercados eficientes, formalizada nos trabalhos de Fama (1970).

De forma a aprofundar o debate a respeito do distanciamento do preço justo de um ativo, este trabalho traça um diálogo com a teoria das finanças comportamentais, avaliando a forma como o comportamento influencia a tomada de decisão do investidor profissional. A sugerida existência de erros de julgamento contraria as bases da hipótese de mercados eficientes, permitindo que o preço de um ativo se distancie de seu valor fundamental. Seria a regulação necessária para adequar estes dois conceitos conflitantes? 
Neste sentido, foi realizada uma pesquisa bibliográfica a respeito da evolução da regulação prudencial. Este trabalho demonstra que, apesar do clamour público por um acirramento do arcabouço regulatório - e mesmo do aumento da participação do Estado na redução do risco sistêmico no mercado financeiro - houve efetivamente grande evolução da regulação dos mercados, sobretudo a partir do final da década de 80 .

Tratando especificamente do caso brasileiro, este trabalho demonstra que o arcabouço regulatório local acompanhou a evolução das diretrizes referentes à regulação dos mercados no mundo - fator preponderante para que o país sofresse em menor intensidade as conseqüências da crise de 2007/2008.

Finalmente, seguindo a metodologia do estudo de evento, as hipóteses deste trabalho avaliaram se os eventos regulatórios observados alteraram o risco dos bancos listados na Bolsa de Valores de São Paulo.

Considerando que a imposição de amarras regulatórias pode impactar de distintas formas bancos de distinto porte, a amostra dos bancos analisados foi subdividida em dois grupos, seguindo o critério do tamanho do ativo total.

A primeira hipótese avaliou o impacto para o grupo formado pelos $50 \%$ maiores bancos, e a segunda hipótese para o grupo formado pelos $50 \%$ menores bancos.

As duas hipóteses foram testadas em dois eventos. O primeiro refere-se ao Comunicado número 12.746, de 8 de dezembro de 2004, marco na regulação prudencial no Brasil, com o anúncio da forma como a nova estrutura de capital Basiléia II - seria implementada no Brasil. O segundo refere-se à concordata do banco Lehman Brothers, em 15 de setembro 2008, estopim da crise, e momento em que a necessidade de revisão do arcabouço regulatório passou a ser debatido com maior intensidade.

A variável dependente analisada neste estudo, ou seja, o risco dos bancos observados, foi medida pelo beta referente ao período amostral analisado.

Por meio da aplicação do teste de comparação de médias emparelhadas verificou-se que o risco dos bancos atuantes na Bolsa de Valores de São Paulo não foi impactado, de forma estatisticamente significante, pelos marcos regulatórios 
analisados. Os resultados indicam que não houve alterações no risco nos dois grupos testados, ou seja, no grupo formado pelas $50 \%$ maiores intuições do mercado e no grupo formado pelas $50 \%$ menores instituições.

Os resultados das análises devem ser interpretados com ressalva. Para o cálculo do beta dos bancos, utilizou-se como proxy da carteira de mercado o índice Bovespa, composta apenas por um grupo seleto de ações. A carteira de mercado definida por Sharpe (1970) possui um perfil mais amplo, sendo composta por todos os ativos de uma economia, como ações, ouro, imóveis, e debêntures.

Finalmente, a estabilidade econômica do país na última década e o amadurecimento do mercado de capitais brasileiro, gerando o boom de IPOs a partir de 2004, são fatores que podem ter influenciado o comportamento das ações dos bancos - e conseqüentemente do beta - durante o período analisado.

Assim, o comportamento do beta dos bancos analisados pode ter sido influenciado por outros fatores além da regulação dos mercados, distorcendo a avaliação do real impacto dos eventos regulatórios sobre o componente de risco dos bancos.

A aplicação da mesma metodologia de estudo deste trabalho para dados de outros países pode contribuir para o aprofundamento do entendimento a respeito do tema. Novos estudos podem ainda averiguar o efeito da regulação sobre outros aspectos relevantes para o nível de estabilidade do sistema financeiro nacional, como o grau de alavancagem das instituições financeiras. 


\section{REFERÊNCIAS BIBLIOGRÁFICAS}

ALDRIGHI, Dante. M.; MILANEZ, Daniel. Y. Finança Comportamental e a Hipótese dos Mercados Eficientes. Revista de Economia Contemporânea, Rio de Janeiro, 9(1): 41-72, jan/abr 2005.

ALVES, Sergio D.; ALVEZ, Tatiana M. A Experiência brasileira de regulação: um caso de sucesso? In: Garcia, Marcio e Giambiagi, Fabio(org).Risco e Regulação, Rio de Janeiro, Elsevier, 2010.

ANNEMA, André; GOEDHART, Marc. H., A Better Beta. The McKinsey Quarterly, Number 1, 2003.

BACEN. Banco Central do Brasil. Comunicado 12.746, de 09 de dezembro de 2004. Comunica os procedimentos para a implementação da nova estrutura de capital - Basiléia II.

Comunicado 16.137, de 27 de setembro de 2007. Comunica os procedimentos para a implementação da nova estrutura de capital - Basiléia II.

BACHELIER, Louis. (1900), Theory Of Speculation", In Cootner, P (Editors), The Random Character Of Stock Market Prices, Cambridge, MA: The M.I.T. Press 1964.

BARBERIS, Nicholas; THALER, Richard. A survey of behavioral finance. Handbook of the Economics of Finance. New York: Elsevier Science, 2003.

BARTHOLDY, Jan; PEARE, Paula. Estimating the Cost of Equity, Aarhus School of Business, Working Paper. SSRN, 2000.

BASEL COMITTE ON BANKING SUPERVISION - BCBS. International Convergence of Capital Measurement and capital Standards. Basel Committee Publication, 1988.

BASEL COMITTE ON BANKING SUPERVISION - BCBS. Implementation of Basel II: practical considerations.Basiléia. Basel Committee Publication, 2004. 
BAZERMAN, Max. Processo decisório. Rio de Janeiro: Elsevier, 2004.

BELLIZIA, Nathalia W. Aplicação do CAPM para a determinação do custo de capital próprio no Brasil. São Paulo, 2009. Dissertação (Mestrado em Administração) - Programa de Pós-Graduação em Administração, Departamento de Administração, Faculdade de Economia, Administração e Contabilidade da Universidade de São Paulo.

BERNANKE, Ben. Speech at the Council on Foreign Relations, Washington, D.C., 2009.

BIS, Bank of International Settlements. [on-line] Available: <http://www.bis.org> Acesso em 22 julho. 2010.

BOLIVAR neto; RIBEIRO, Adriana. Evolução financeira internacional, acordo de Basiléia II e perspectivas do sistema financeiro brasileiro 1. In: Mendonça, Ana Rosa R. e Andrade, Rogério P. (org.) Regulação Bancária e Dinâmica Financeira. Campinas, Instituto de Economia da Unicamp; 2006.

BREALEY, Richard et al. Princípios de Finanças corporativas. 8 ed. São Paulo: Mcgraw-hill, 2008.

BRENNER, Robert. O Boom e a Bolha. Rio de Janeiro: Editora Record., 2002.

BRESSER-PEREIRA, Luiz Carlos, A crise financeira global e depois: um novo capitalismo, Novos Estudos Cebrap 86: 51-72, 2010.

BUFFETT, Mary; CLARK, David. O Tao de Warren Buffett: Como aplicar a sabedoria e os princípios de investimento do gênio das finanças em sua vida. Rio de Janeiro: Editora Sextante, 2007.

CAMPBELL, John Y..; LO, Andrew W.; MACKINLAY, Craig, A. The Econometrics of Financial Markets. New Jersey: Princeton University Press, 1997. 
CANUTO, Otaviano. E LIMA, Gilberto T. Regulação bancária no Mercosul. In: Baumann, R. (org.), Mercosul - avanços e desafios da integração, Brasília: IPEA/CEPAL, 2001.

CARVALHO, Demerval Bicalho; CALDAS, Marcelo Petroni. Basiléia II: abordagem prática para acompanhamento de risco operacional em instituições financeiras. Resenha BM\&F Brasil. [s.d.], p. 76- 84. [On-line]. Available: http://www.febraban.org.br/Arquivo/Servicos/Imprensa/Artigo_Basileia_6.pdf> Acesso em 20 de abril 2010.

CARVALHO, Fernando. Inovação financeira e regulação prudencial: da regulação de liquidez aos acordos da Basiléia”, In R. Sobreira (org), Regulação Financeira e Bancária, São Paulo: Atlas, pp. 121/137, 2005.

CORAZZA, Gentil. Os dilemas da supervisão bancária. In: SOBREIRA, Rogério. (Org.). Regulação Financeira e Bancária. São Paulo: Editora Atlas, 2005, v. p.8296.

CORNFORD, Andrew. Basiléia II: o Novo Acordo de 2004, In: MENDONÇA, Ana Rosa R. de \& ANDRADE, Rogério P. de (Org.) Regulação bancária e dinâmica financeira: evolução e perspectivas a partir dos Acordos de Basiléia. Campinas: IE/Unicamp, p.39-91, 2006.

CUNNINGHAM, Lawrence A., Behavioral Finance and Investor Governance . Washington \& Lee Law Review, Vol. 59, p. 767, 2002.

DAMODARAN, Aswath. Estimating risk parameters. World Bank working paper, 1999.

DAWES, Robyn. Rational Choice in an Uncertain World. Orlando: Harcout Brace Jovanovich, 1988.

DUARTE Jr., Antonio. M.. Risco: definições, tipos, medição e recomendações para seu gerenciamento. Resenha BM\&F, novembro/dezembro, pp. 25 - 33, 1996.

ELTON, Edwin J.; GRUBER, Martin J., Modern Portfolio Theory and Investment Analysis, 5th ed. New York: John Wiley \& Sons, Inc, 1995. 
FAMA, Eugene. F.; Efficient capital markets: a review of theory and empirical work. The Journal of Finance, v.25, n.2, p. 383-417, May 1970.

FRENCH, Kenneth. R. The capital asset pricing model: theory and evidence. Journal of Economic Perspectives. V.18, n.3, p. 25-46, 2004.

FAMÁ, Rubens.; CARDOSO, Ricardo. L; MENDONÇA, Oávioct. Riscos Financeiros e não Financeiros: Uma Proposta de Modelo para Finanças. Cadernos da FACECA v. 11 n. 1 jan/jun 33-50, 2002.

FAVERO, Luiz P.; BELFIORE, Patricia; SILVA, Fabiana L. da; e CHAN, Betty L. Análise de Dados: Modelagem Multivariada para Tomada de Decisões. Rio de Janeiro: Elsevier, 2009.

FORTUNA, Eduardo. Mercado financeiro: produtos e serviços. 3.ed. Rio de Janeiro: Qualitymark, 320p, 1993.

FRANKFURTER, George. M.; MCGOUN, Elton. G., Resistance is futile: the assimilation of behavioral finance. Journal of Economic Behavior \& Organization 48, 375-389, 2002.

FRAZZINI, Andrea. The disposition effect and under-reaction to news. The Journal of Finance, v.61, p.2017 - 2046. Agosto, 2006.

GALBRAITH, John. A short history of financial euphoria, Whittle Books, New York. NY, 1993.

GENESOVE, David.; MAYER, Christopher. Loss aversion and seller behavior: evidence from the housing market. Quarterly Journal of Economics, n. 116, p. 1233-1260, 2001.

GREENSPAN, Alan.; A era da turbulência: aventuras em um novo mundo. Elsevier, 2008. 
GRINBLATT, Mark.; KELOHARJU, Matti. The Investment Behavior and Performance of Various Investor Types: A Study of Finland's Unique Data Set. Journal of Financial Economics, n. 55, p. 43-67, 2000.

GOLDBERG, Joachim; NITZSCH, Rudiger. Behavioral finance. Chichester: John Wiley \& Sons, 2001.

GUIMARÃES, Andre L., LIMA, Jorge C., Avaliação de risco de crédito no Brasil In: Garcia, Marcio e Giambiagi, Fabio(org). Risco e Regulação, Rio de JaneiroElsevier, 2010.

GUTTMANN, Robert, Basiléia II: uma nova estrutura para a regulação da atividade bancária global. In: Mendonça, Ana Rosa R. e Andrade, Rogério P. (org.) Regulação Bancária e Dinâmica Financeira. Campinas, Instituto de Economia da Unicamp, 2006.

JORION, Philippe. Value at Risk - The New Benchmark for Managing Financial Risk. $2^{\circ}$ ed. New York: MacGraw-Hill, 2000.

KAHNEMAN, Daniel., SLOVIC, Paul; TVERSKY, Amos. (Eds.) Judgment Under Uncertainty: Heuristics and Biases. New York: Cambridge University Press, 1982.

KAHNEMAN, Daniel.; TVERSKY, Amos. Subjective probability: a judgment of representativeness. Cognitive Psychology, v.3, pp. 430-454, 1972.

Prospect Theory: an analysis of decision under risk. Econometrica, v.47, p.263-291, 1979.

KREGEL, Jan. O novo Acordo de Basiléia pode ser bem-sucedido naquilo em que o Acordo Original fracassou? In: Mendonça, Ana Rosa R. e Andrade, Rogério P. (org.) Regulação Bancária e Dinâmica Financeira. Campinas, Instituto de Economia da Unicamp, 2006.

LIMA, Gilberto T. Evolução Recente da Regulação Bancária no Brasil. In: SOBREIRA, Rogério. (Org.). Regulação Financeira e Bancária. São Paulo: Editora Atlas, v. , p. 185-209, 2005. 
LINTNER, John. The valuation of risk assets and the selection of risky investments in stock portfolios and capital budgets. The Review of Economics and Statistics. [S.1.], v. 47, n. 1, p. 13-37, feb. 1965.

LUENBERGER, David G. Investment science. New York: Oxford University Press, 1998.

MACKINLAY, A. Craig. Event studies in economics and finance. Journal of Economic Literature, Nashville: American Economic Association, v.35, n. 1, p. 13-39, Mar. 1997.

MALAN, Pedro S. Uma visão abrangente sobre a crise e o processo de sua superação In: GARCIA, Marcio; GIAMBIAGI, Fabio(org). Risco e Regulação, Rio de Janeiro, Elsevier, 2010.

MÁlAGA, Flávio K. Estudo do risco sistêmico das empresas resultantes de fusões e aquisições e as expectativas dos investidores e dos gestores. São Paulo, 2003. Tese (Doutorado em Administração) - Programa de Pós-Graduação em Administração, Departamento de Administração, Faculdade de Economia, Administração e Contabilidade da Universidade de São Paulo.

Aplicação do modelo de três fatores de Fama e French no mercado acionário brasileiro: um estudo empírico do período 1995-2003. São Paulo, 2003. Dissertação (Mestrado em Administração) - Programa de Pós-Graduação em Administração, Departamento de Administração, Faculdade de Economia, Administração e Contabilidade da Universidade de São Paulo.

MANDELBROT, Benoit. Forecasts of Future Prices, Unbiased Markets, and 'Martingale' Models. Journal of Business, Vol. 39, No. 1, pp. 242-255, 1966.

MARCONI, Marina de A.; LAKATOS, Eva M. Fundamentos da metodologia científica. 6 ed. São Paulo: Atlas, 2005.

MARKOWITZ, Harry M. Foundations of Portfolio Theory. The Journal of Finance. [S.1.], v. 46, n. 2, p. 469-477, jun. 1991. 
Portfolio selection. The Journal of Finance. [S.1.], v. 7, n. 1, p. 77-91, mar. 1952.

Portfolio selection: efficient diversification of investment.[S.1.], Cowles Foundation, 1959.

MENDONÇA, Igor. D. O processo de estruturação organizacional da diretoria de fiscalização do Banco Central do Brasil no período de 1999 a 2005. Dissertação de Mestrado, Universidade Federal do Paraná, Curitiba, Brasil, 2006.

MILANEZ, Daniel. Y. Finanças comportamentais no Brasil. Dissertação (Mestrado em Economia) - Faculdade de Economia, Administração e Contabilidade, Universidade de São Paulo, 2003.

MORANDI, Andre; FIRMO, Marcio G., Regulação: errada, incompleta ou não aplicada? In: GARCIA, Marcio; GIAMBIAGI, Fabio(org). Risco e Regulação, Rio de Janeiro Elsevier, 2010.

MOSSIN, Jan. Equilibrium in a capital asset market. Econometrica, v. 34, n. 4, p. 768-783, 1966.

NETO, Bolivar; RIBEIRO, Adriana. Evolução Financeira Internacional, Acordo de Basiléia II e perspectivas do sistema financeiro Brasileiro?. In: Mendonça, Ana Rosa R. e Andrade, Rogério P. (org.) Regulação Bancária e Dinâmica Financeira. Campinas, Instituto de Economia da Unicamp, 2006.

NÓBREGA, Mailson da, Origens da Crise In: Garcia, Marcio; Giambiagi, Fabio(org). Risco e Regulação, Rio de Janeiro, Elsevier, 2010.

ODEAN, Terrance. Are investors reluctant to realize their losses? In: KAHNEMAN, Daniel; TVERSKY, Amos. (Eds.) Choices, Values and Frames. New York: Cambridge University Press, 2000.

PEROLD, André. The Capital Asset Pricing Model. Journal of Economic Perspectives 18, no. 3: 3-24, 2004. 
PUGA, Fernando P. Sistema financeiro brasileiro: reestruturação recente, comparações internacionais e vulnerabilidade à crise cambial. Texto para discussão no 68, março, BNDES, 1999.

Ritter, Jay R., Behavioral Finance. Pacific-Basin Finance Journal. v. 11, n. 4, p. 429-437, 2003.

ROLL, Richard. A critique of the asset pricing theory's tests. Journal of Financial Economics, v.4, p.129-176, 1977.

ROSS, Stephen, et al. Administração financeira. 2 ed. São Paulo: Atlas, 2007.

SAMUELSON, Paul A. Proof That Properly Anticipated Prices Fluctuate Randomly. Industrial Management Review, Vol. 6, pp. 41-49, 1965.

SAUNDERS, Anthony. Administração de instituições financeiras. São Paulo: Atlas, 2000.

SAVAGE, Leonard J. The Foundations of Statistics. New York: Wiley, 1954.

SECURATO, José R. Decisões financeiras em condições de risco. São Paulo: Saint Paul Editora, 2007.

SHAPIRA, Zur; VENEZIA, Itzhak. Patterns of Behavior of Professionally Managed and Independent Investors. Journal of Banking and Finance, n. 25, p. 1573-1587, 2001.

SHARPE, William F. et al. Investments. 4th ed. New Jersey: Prentice Hall, 1999.

Sharpe, W. F. . Capital asset prices with and whitout negative holdings. Journal of Finance, p. 489-509, 1991.

SHARPE, William F. Capital asset prices: a theory of market equilibrium under conditions of risk. The Journal of Finance. [S.1.], v. 19, n. 3, p. 425-442, jul. 1964. 
Portfolio theory and capital markets. [S.1.]: McGraw-Hill, 1970.

SHEFRIN, Hersh, STATMAN, Meir. Ethics, fairness and efficiency in financial markets. Financial Analysts Journal, p.21-29, Nov./Dec., 1993.

. The Disposition to Sell Winners Too Early and Ride Losers Too Long:

Theory and Evidence, Journal of Finance v. 40, n. 3, p. 777-791, 1985.

Beyond greed and fear: understanding behavioral finance and the

psychology of investing. New York: Oxford University Press, 2002.

SHLEIFER, Andrei; VISHNY, Robert W. The Limits of Arbitrage, Journal of Finance v. 52, n. 1, p. 35-55, 1997.

SHILLER, Robert. Human behavior and the efficiency of the financial system. In: J. Taylor e M. Woodford (eds.), Handbook of Macroeconomics. Amsterdam: Elsevier, 1999.

Exuberância irracional. São Paulo: Makron Books, 2000.

SILBER, Simão. A economia mundial após a crise financeira de 2007 e 2008. Balanço da Crise mundial. Revista da USP, 2010.

SIEGEL, Jeremy J. The Shrinking Equity Premium. Journal of Portfolio Management. V.26, p.10-16, 1999.

SIMON, Herbert A. Models of Man. New York: Wiley, 1957.

STIGLITZ, Joseph (2009). Too Big to Fail or Too Big to Save? Examining the Systemic Threats of Large Financial Institutions. Washington D.C., Testimony for the Joint Economic Committee, 2009.

STULZ, René. Rethinking risk management. Journal of applied corporate finance, v. 9, n. 5, p 8-24, 1996. 
THALER, Richard. The end of behavioral finance. Financial Analysts Journal, v. 55, n. 6, Nov-Dec, 1999.

. THALER, Richard. The January effect. Journal of Economic Perspectives, n. 1, v. 1, p. 197-201, 1987.

TREYNOR, Jack. L. Toward a Theory of Market Value of Risky Assets manuscrito não publicado, 1961 In FRANCIS J.Clark. Investments- McGraw Hill 5th Edition- 1991.

TVERSKY, Amos; KAHNEMAN, Daniel. Judgment under Uncertainty: Heuristics and Biases. Science, v. 185, p. 1124-1131, 1974.

The framing of decisions and the psychology of choice. Science, v.211, January 1981.

VON NEUMANN, John, MORGENSTERN, Oskar. (1944), Theory of Games and Economic Behavior, 3rd edition, Princeton University Press, 1944.

WOOLRIDGE, J. Randal. Do Stock Prices Reflect Fundamental Values? Journal of Applied Corporate Finance. v.8. p 64-69, 1995.

YOSHINAGA, Claudia E.; OLIVEIRA, Raquel F.; SILVEIRA Alexandre di Miceli; BARROS, Lucas A. Finanças comportamentais: uma introdução. In: VII SEMINÁRIOS EM ADMINISTRAÇÃO FEA USP, São Paulo, 2004. 